California State University, Monterey Bay

Digital Commons @ CSUMB

Monterey County Water Resources Agency

Engineering Reports

Monterey County Water Resources Agency

$1-2-2019$

\title{
2003 - Geohydrologic Framework of Recharge and Seawater Intrusion in the Pajaro Valley, Santa Cruz and Monterey Counties, California
}

Follow this and additional works at: https://digitalcommons.csumb.edu/hornbeck_cgb_6_b

Part of the Business Commons, Education Commons, Engineering Commons, Life Sciences

Commons, Physical Sciences and Mathematics Commons, and the Social and Behavioral Sciences

Commons

\section{Recommended Citation}

"2003 - Geohydrologic Framework of Recharge and Seawater Intrusion in the Pajaro Valley, Santa Cruz and Monterey Counties, California" (2019). Monterey County Water Resources Agency Engineering Reports. 8.

https://digitalcommons.csumb.edu/hornbeck_cgb_6_b/8

This Report is brought to you for free and open access by the Monterey County Water Resources Agency at Digital Commons @ CSUMB. It has been accepted for inclusion in Monterey County Water Resources Agency Engineering Reports by an authorized administrator of Digital Commons @ CSUMB. For more information, please contact digitalcommons@csumb.edu. 


\title{
Kennedy/Jenks Consultants
}

622 Folsom Street San Francisco, California 94107

415-243-2150

415-896-0999 (Fax)

www.KennedyJenks.com

\section{FINAL REPORT \\ Hydrostratigraphic Analysis \\ of the \\ Northern Salinas Valley}

14 May 2004

\author{
Prepared for \\ Monterey County \\ Water Resources Agency \\ 893 Blanco Circle \\ Salinas, California 93901
}

K/J Project No. 035901.00 


\section{Kennedy/Jenks Consultants}

\section{FINAL REPORT}

\section{HYDROSTRATIGRAPHIC ANALYSIS OF THE NORTHERN SALINAS VALLEY}

14 May 2004

Project No. 035901.00

This report was prepared by Kennedy/Jenks Consultants, Inc., under the direction of the Monterey County Water Resources Agency (Agency), the only intended beneficiary of this work. No other party should rely on the information presented herein without the consent of the Agency.

The findings, recommendations, specification, or professional opinions are presented within the limits described by the client, in accordance with generally accepted professional engineering and geologic practice. No warranty is expressed or implied.

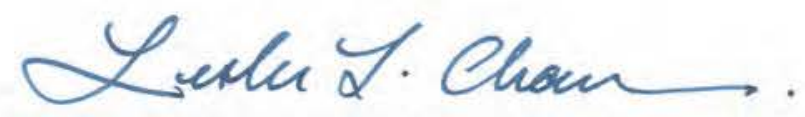

Leslie L. Chau

Principal Hydrogeologist, Project Manager
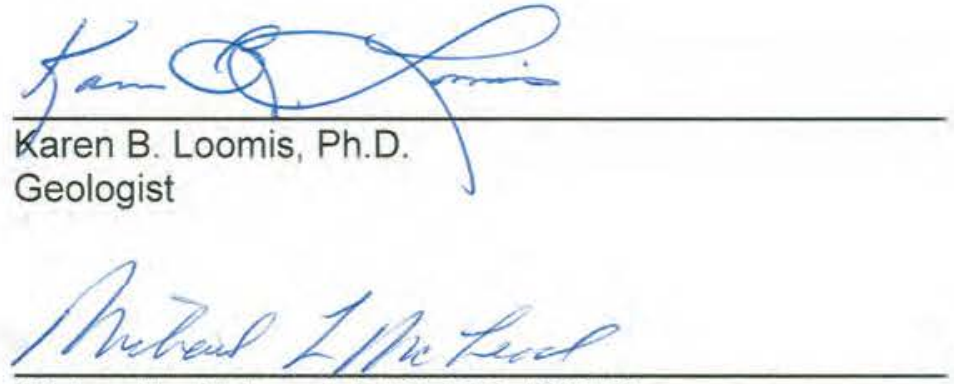

Michael L. McLeod, R.G. (CA \#5977)

Geologist 


\section{Table of Contents}

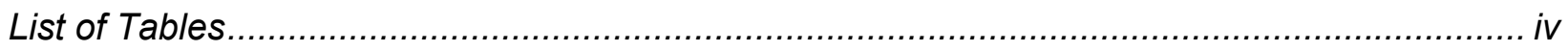

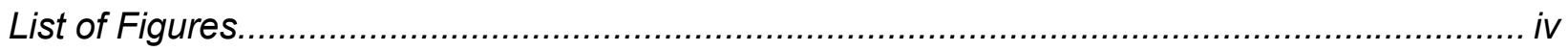

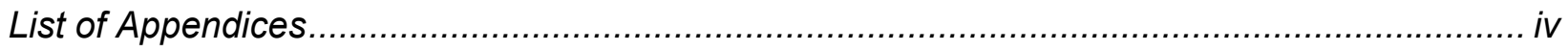

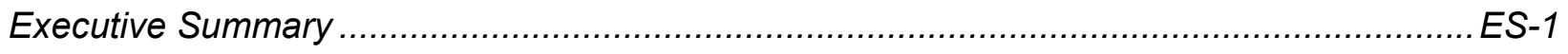

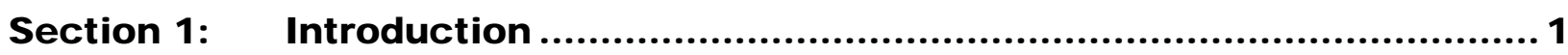

$1.1 \quad$ Project Background and Study Goals .......................................

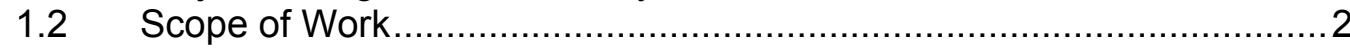

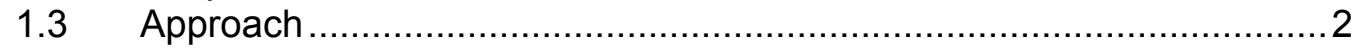

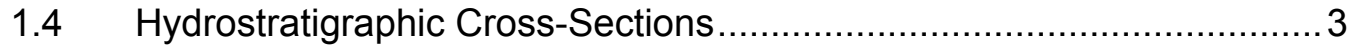

1.5 Previous Studies ................................................................

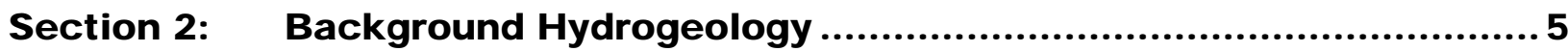

2.1 Geographic and Hydrologic Settings ................................................ 5

$2.2 \quad$ Pressure and East Side Subareas .................................................. 5

2.3 Stratigraphy of the Northern Salinas Valley .................................... 6

2.3.1 Recent Alluvium............................................................... 6

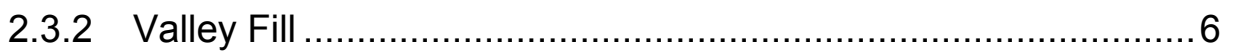

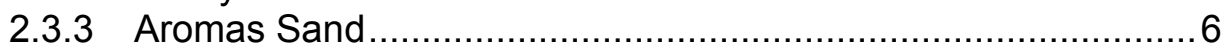

2.3.4 Paso Robles Formation ................................................ 6

2.3.5 Older and Deeper Geologic Formations that Underlie the Pressure 400-Foot Aquifer ............................................ 7

2.3.5.1 Purisima Formation.......................................... 7

2.3.5.2 Santa Margarita Formation .............................. 7

2.3.5.3 Monterey Formation........................................ 7

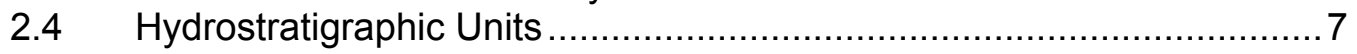

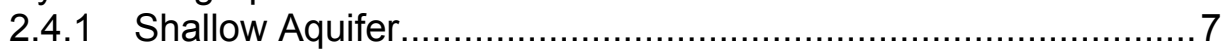

2.4.2 Salinas Valley Aquitard................................................ 7

2.4.3 Pressure 180-Foot Aquifer ........................................... 8

2.4.4 Pressure 180/400-Foot Aquitard …................................... 8

2.4.5 Pressure 400-Foot Aquifer ............................................ 8

2.4.6 Pressure 400-Foot/Pressure Deep Aquitard ........................ 9

2.5 Depositional Environments of the Pressure and East Side

Subareas .......................................................................... 9

Section 3: $\quad$ Discussion - Pressure Subarea Hydrogeology ..................... 11

3.1 Pressure Subarea Hydrostratigraphy ....................................... 11

3.1.1 Shallow Ground Water Aquifer ...................................... 11

3.1.2 Salinas Valley Aquitard.................................................. 11 


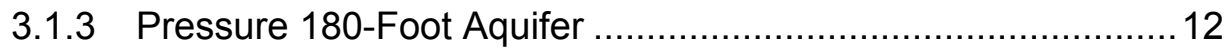

3.1.4 Pressure 180/400-Foot Aquitard ....................................... 12

3.1.4.1 Absence of Confining Clay Unit ............................. 12

3.1.5 Pressure 400-Foot Aquifer ............................................... 14

3.1.5.1 Locations of the Thickest Sand Zones.................... 14

3.1.6 Pressure 400-Foot/Pressure Deep Aquitard ..........................15

3.2 Ground Water Elevations ……………………………………... 15

Section 4: Discussion - East Side Subarea Hydrogeology ....................... 17

4.1 East Side Subarea Geologic Setting ................................................. 17

4.2 East Side Subarea Hydrostratigraphy ...........................................17

4.3 Depositional Facies in the Pressure/East Side Transition Zone …....... 18

4.3.1 Alluvial Fan Facies ........................................................ 18

4.3.1.1 Proximal Alluvial Fan Facies................................. 19

4.3.1.2 Alluvial Plain Facies ........................................... 19

4.3.2 Fluvial Facies............................................................ 19

4.3.2.1 Fluvial Channel Facies ………………………....19

4.3.2.2 Fluvial Overbank Facies …………………….......20

$4.4 \quad$ East Side Subarea Ground Water.................................................2

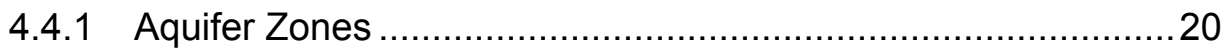

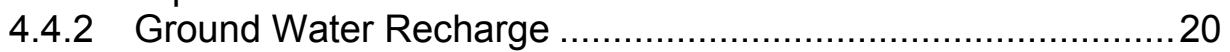

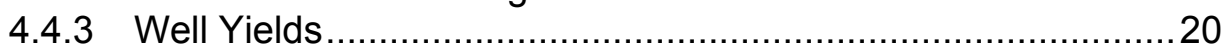

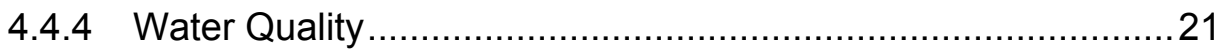

Section 5: Transition Between Pressure and East Side Subareas ............. 22

5.1 Boundary Between the Pressure and East Side Subareas.................22

5.1.1 Boundary as Defined by Earlier Studies .................................22

5.1.2 Boundary as Defined in the Study .......................................22

5.2 Transition Zone Between Pressure and East Side Subareas -

Stratigraphic Characteristics ........................................................22

5.2.1 Stratigraphic Facies Scenarios ........................................... 23

5.2.2 Characteristics of the Pressure 180-Foot and Pressure 400-Foot Aquifers Near the Transition Zone …………............2 24

5.3 Depositional Model..................................................................25

5.3.1 Sediment Sources in the Northern Salinas Valley ....................25

5.3.2 Glacio-Eustatic Control of Depositional Facies .......................25

5.3.3 Interaction Between Fluvial and Alluvial Fan Depositional

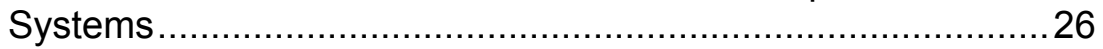

5.3.4 Sediment Provenance and the Southward Progression

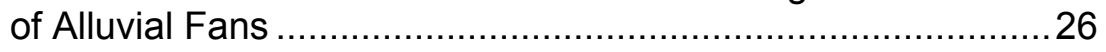

5.3.5 Distribution of Depositional Facies ………………................ 27

5.4 Hydraulic Connectivity of East Side Subarea and Transition

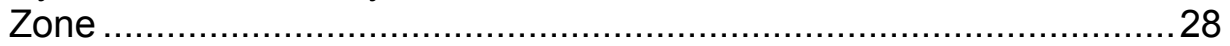


5.4.1 Depositional Facies Control of Hydraulic Connectivity .............28

5.4.2 Hydraulic Properties of Transition Zone ……….....................2 29

5.4.3 Possible Areas of Horizontal and Vertical Hydraulic

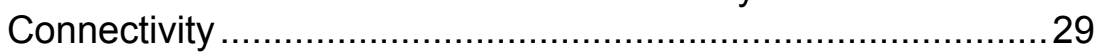

5.4.3.1 Horizontal Flow Across Pressure/East Side Boundary …...................................................29

5.4.3.2 Vertical Flow within the East Side Subarea ..............30

5.4.3.3 Horizontal Flow within the Pressure Subarea ..........30

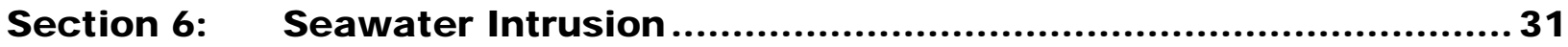

6.1 Mechanisms of Seawater Intrusion ....................................................31

6.1.1 Three Seawater Intrusion Mechanisms in the Northern Salinas Valley ................................................................ 31

6.2 Methods of Assessing the Rate of Seawater Intrusion...........................32

6.2.1 The Ghyben-Herzberg Principle …………….........................33

6.2.2 Mapping of Chloride Front .................................................... 33

6.3 Regional Seawater Intrusion ....................................................... 34

6.4 Regional Seawater Intrusion in the Pressure 180-Foot Aquifer ............34

6.5 Regional Seawater Intrusion in the Pressure 400-Foot Aquifer ............36

6.6 Seawater Intrusion through Natural Aquitard Leakage ..........................37

6.7 Hydraulic Communication between the Pressure and East Subareas ................................................................................

6.8 Estimated Rates of Seawater Intrusion and Impacts to Water

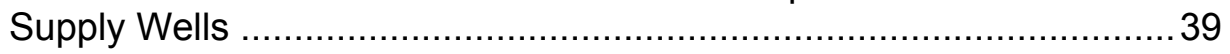

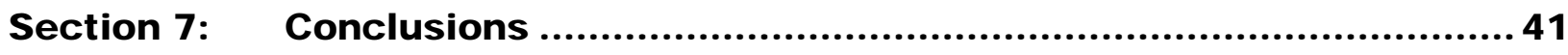

7.1 Pressure Subarea Hydrostratigraphy …………………………....41

7.2 East Side Subarea and Transition Zone Hydrostratigraphy ................4 42

7.3 Regional Seawater Intrusion .......................................................... 42

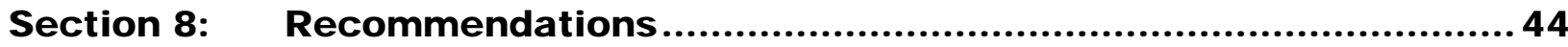

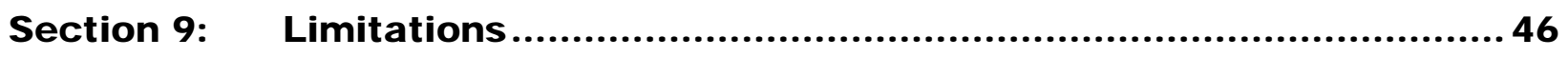

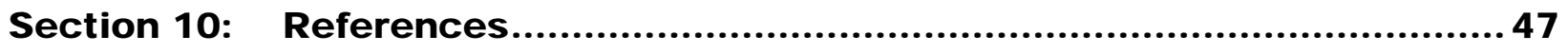




\section{List of Tables}

1 List of Well Logs Used in Cross-Sections

2 Sedimentary and Hydraulic Characteristics of the Pressure and East Side Subareas

3 Pressure Subarea Estimated Seawater Intrusion Rates

\section{List of Figures}

1 Study Area - Pressure and East Side Sub Areas

2 Cross-Section Location Map

3 Cross-Section A-A'

4 Cross-Section B-B'

5 Cross-Section C-C'

6 Cross-Section D-D'

7 Cross-Section E-E'

8 Cross-Section F-F'

9 Cross-Section G-G'

10 Possible Discontinuities in the Pressure 180/400-Foot Aquitard

11 Generalized Fluvial and Alluvial Fan Facies of Northern Salinas Valley

12 Transition Zones Between Fluvial Facies and Alluvial Facies

13 Facies Scenario 1

14 Facies Scenario 2

15 Facies Scenario 3

16 Extent of Blue Clay (Salinas Aquitard) Facies and Alluvial Fan Facies

17 Distribution of Depositional Facies during Pressure 180-Foot Aquifer "Time"

18 Distribution of Depositional Facies during Pressure 400-Foot Aquifer "Time"

19 Historic Seawater Intrusion Map and Inferred Travel Paths, Pressure 180-Foot Aquifer

20 Historic Seawater Intrusion Map and Inferred Travel Paths, Pressure 400-Foot Aquifer

\section{List of Appendices}
A Report Glossary
B List of References Reviewed 
Kennedy/Jenks Consultants

\section{Executive Summary Hydrostratigraphic Analysis of the Northern Salinas Valley}

\section{Introduction}

The Monterey County Water Resources Agency (Agency), responsible for the management and planning of water resources within Monterey County, uses a network of wells to monitor ground water conditions in the Salinas Valley ground water basin (Figure 1); The progressive advancement of the seawater intrusion front into ground water zones and the understanding of the northern Salinas ground water basin hydrogeology have been documented by the Agency since the 1950s. Only in the later 1990s and recently have there been sufficient well logs, geophysical, and lithological data to support a three-dimensional (3-D) study of the inter-related ancestral fluvial and alluvial-fan depositional environments that make up the present day ground water bearing zones known as the Pressure 180-Foot and Pressure 400-Foot aquifers and their implications on seawater intrusion pathways.

Findings in this hydrostratigraphic study confirm that the main ground water bearing zones are likely of fluvial origin which has a classic sequence of thick, well-defined beds of sand and gravel separated by blue clays. This sequence was formed by repeated glacio-eustatic sea level fluctuations, which resulted in cycles of marine transgressions and valley fill incisions and subsequent alluviation. Sequences of coarser sediments separated by brown clays of alluvial fan origin are observed along the northeastern edge of the elongate northern pressure zone.

These depositional environments were evaluated with the stratigraphic correlation of a series of northeast to southwest cross-sections sequentially located from the City of Salinas to the coast and then connected by a northwest-southeast profile. This study included a 3-D conceptual model of the lithostratigraphic makeup of the paleo-depositional environmenti(Figure 2)i. The ability to examine 3-D distributions of interbedded clays and coarse-grained sédiments, particularly in a transition zone,(Figure 2$)$ from estuarine to alluvial fans, suggests lower permeability and slower ground water movements flows in the East Side Subarea which consists of interfinger fluvial overbanks, alluvial plain, and coarser alluvial sediments. As importantly, this analysis confirms areas of absence and thinning of aquitard materials that separate the Pressure 180- and Pressure 400-Foot aquifers in the Pressure Subarea.

The economic importance of a detailed rendition of hydrostratigraphic characteristics is to assist in the construction and placement of future water supply and monitoring wells within the study area. This is the primary area of interaction between intruding seawater and ground water of the Pressure 180-Foot and the Pressure 400-Foot ground water aquifers. Seawater is intruding into the ground water zones from the submarine outcrops of and directly into the Pressure 180- and Pressure 400-Foot aquifers. Moreover, our stratigraphic analysis demonstrates with notably more detailed lithologic data that mixing and vertical migration of seawater are highly possible in several localized areas between the coast and the City of Salinas. Vertical movement of seawater/ground water is likely across leaky aquitard and areas of the absence of confining clay 


\section{Kennedy/Jenks Consultants}

unit between the Pressure 180-Foot and Pressure 400-Foot Aquifers. It is therefore of importance to the public water supply of the northern Salinas Valley that the 3-D permeability distribution of the lithology be mapped with enough detail to assist in the design of future engineering measures to mitigate the seawater intrusion problem.

\section{Project Background and Study Goals}

This study as intended by the Agency is the work of a focused analysis and update of the hydrogeologic interpretations to augment the ongoing assessment of rates of seawater intrusion into the Pressure 180-Foot Aquifer and the Pressure 400-Foot Aquifers. The occurrence of seawater intrusion into the Pressure 180-Foot Aquifer in the areas between the City of Salinas and the coast was first documented in 1933 by the State of California. Continued seawater intrusion to present day is largely attributed to overdraft of ground water from the Pressure 180-Foot Aquifer. Withdrawals from both the Pressure 180-Foot Aquifer and the Pressure 400-Foot Aquifer have lowered water levels below sea level. Seawater intrusion into the Pressure 400-Foot Aquifer has been slower and less extensive than in the overlying Pressure 180-Foot Aquifer because the Pressure 400-Foot Aquifer was not drawn upon until water quality in the Pressure 180-Foot Aquifer had been significantly degraded. However, in recent studies, the integrity of the aquitard that separates the Pressure 180-Foot Aquifer and the Pressure $400-F o o t$ Aquifer has been the subject of detailed hydrogeologic interpretations using new data and reinterpretations of previous results. This study examines evidence of localized thinning and absence of the clay layer that likely results in interaquifer migration or downward gradient flow of ground water and seawater from the Pressure 180-Foot Aquifer to the Pressure 400-Foot Aquifer. Interaquifer contamination is considered as a significant seawater encroachment threat to the current water quality in and supply from primarily the Pressure 400-Foot Aquifer for this area.

\section{Approach}

Our approach in this study was to construct a 3-D hydrogeologic conceptual model of the northern Salinas Valley. With the use of a 3-D geographic information system and a database of over 700 wells, we present a comprehensive update of previous findings based on new lithologic data and introduce three possible scenarios of the ancestral deposition processes that make up the present day hydrogeologic structure. The objective is a focused assessment of adjacent Pressure 180-Foot Aquifer and Pressure 400-Foot Aquifer that span the uppermost 600 feet of sedimentary sequences and are part of the Valley Fill Deposits (Qvf) and the underlying Aromas/Paso Robles Formation (Qar).

We focused our efforts in methodically depicting the hydrostratigraphic characteristics of the Pressure 180-Foot Aquifer and Pressure 400-Foot Aquifer. Our goal in constructing hydrogeologic cross-sections is to identify areas of localized thinning and absence of confining layers, such as the blue clay sequences between the Pressure 180- and Pressure 400-Foot Aquifers. Such details are of particular interest in assessing localized downward flow of ground water. 


\section{Kennedy/Jenks Consultants}

As importantly, historical differences in water levels between the Pressure Subarea and the East Side hydrogeological "Subareas" suggest distinctions in stratigraphy and permeability between the two hydrogeologic regimes. Moreover, the hydrogeologic relationships in the transition zone between these two subareas are assessed and depicted on cross-sections and on hydrogeologic maps.

Note: For brevity, cross-section AA' through GG" panels prepared in this study are excluded in this summary. They are presented in the Final Report and it is available to the public upon request at the Agency. We have depicted our cross-sectional interpretations of the hydrogeologic features on maps and are presented herein as figures.

\section{Hydrogeology}

The Salinas Valley Ground Water Basin is situated entirely within Monterey County ${ }_{2}$ located along the central California coast approximately 100 miles south of San Francisco! (Figure 1).'

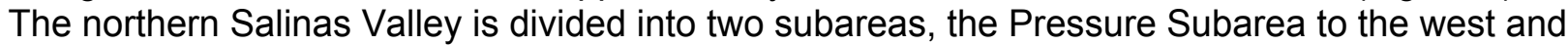
the East Side Subarea to the east (Figure 1) The hydrogeology and ground water behavior in each subarea is markedly different due to different depositional environments and geology.

\section{Ground Water Elevations}

Ground water elevations are monitored regularly by the Agency in the Salinas Valley in monitoring wells and agricultural production wells. Historical ground water elevations reflect drawdown and depressed ground water elevations during the summer irrigation season and recovery of ground water elevations during the winter.

Data collected in 1999 from the Fort Ord area and the western Salinas Valley indicate that ground water elevations in the Pressure 180-Foot Aquifer and Pressure 400-Foot Aquifer were below sea level, with elevations in the Pressure 180-Foot Aquifer as low as -20.7 feet MSL near the Salinas River and elevations in the Pressure 400-Foot Aquifer as low as -51.4 feet MSL east of the Salinas River. The lower ground water elevations in the Pressure 400-Foot Aquifer indicate that a vertical hydraulic gradient downward from the Pressure 180-Foot Aquifer to the Pressure 400-Foot Aquifer exists.

The ground water elevations are below mean sea level in both the Pressure 180-Foot Aquifer and Pressure 400-Foot Aquifer have been consistent for many years, as has been the difference in elevations between the two aquifers (Todd, 1989 and Harding ESE, 2001). Todd (1989) and Harding ESE (2001) suggest that this trend indicates that although the aquitard between the two aquifers may be discontinuous in places, the aquitard is sufficient to consistently support a vertical head difference. The consistent below mean sea level ground water elevations in both aquifers create a situation that promotes continued seawater intrusion. 


\section{Kennedy/Jenks Consultants}

\section{Pressure Subarea 180/400-Foot Aquitard}

The Pressure 180-Foot Aquifer and Pressure 400-Foot Aquifer are separated by a zone of clay, or clay and sand layers (Monterey County Flood Control \& Water Conservation District, MCFCWCD, 1960) referred to as the Pressure 180/400-Foot Aquitard. This barrier is widespread in the Salinas Valley basin and varies in thickness and quality from thick layers of blue clay to thin layers of brown clay (MCFCWCD, 1960).

Variability in thickness and quality of the Pressure 180/400-Foot Aquitard and the existence of possible gaps in the aquitard is well known and is the primary subject of this study. MCFCWCD (1960) describes two small "holes" in the aquitard, one under the Salinas River near Blanco and another under the old Salinas River bed near the coast. The Pressure 180-Foot Aquifer and the Pressure 400-Foot Aquifer also appear to be interconnected in places between Salinas and Chualar (approximately 10 miles south of Salinas) and south of Chualar (MCFCWCD, 1960). Brown (1986) describes the aquitard as generally lenticular in shape and discontinuous in places, notably near the mouth of the Salinas River and near Fort Ord (MCFCWCD, 1960). Todd (1989) indicates several areas between Castroville and the coast where the aquitard is thin or absent.

\section{Seawater Intrusion}

This study assesses the conditions of seawater intrusion by developing a time line of the landward advancement of the seawater intrusion front relative to identified benchmarks such as the City of Salinas and the East Side pumping wells. The 500 milligrams per liter $(\mathrm{mg} / \mathrm{L})$ chloride level has been used by the Agency to demarcate the landward edge of the seawater intrusion front where the denser seawater body has intruded into ground water. This chloride ion concentration is used as an indicator of impact to ground water and it is promulgated as a Secondary Drinking Water Standard upper limit for chloride.

The primary cause for seawater intrusion in this area is that the aquifers are in direct hydraulic contact with the sea. The secondary cause for seawater mixing in the Pressure 180-Foot and Pressure 400-Foot fresh water aquifers is that ground water levels in both aquifers are below sea level and the normal seaward gradient had been reversed in the Pressure 180-Foot Aquifer zone since as the 1930s.

The pattern of encroaching seawater in ground water zones in the northern Salinas Valley - as represented by $500 \mathrm{mg} / \mathrm{L}$ chloride contours - is the result of three primary seawater intrusion mechanisms that have been studied by numerous investigators in this area: 1) seawater infiltrates the Pressure 180-Foot and Pressure 400-Foot Aquifers through the submarine outcrops of aquifers offshore of Monterey Bay by way of a landward hydraulic gradient - regional seawater intrusion; 2) seawater-blended ground water in the Pressure 180-Aquifer migrates downward into the Pressure 400-Foot Aquifer - interaquifer seawater intrusion, and 3) seawater movement between aquifers due to poor well constructions. 


\section{Kennedy/Jenks Consultants}

\section{Methods of Assessing the Rate of Seawater Intrusion}

In this study we assess the expansion of intruded areas based on documented delineations of the chloride levels through time as contours of the front have been published by the Monterey County Flood Control District and now by the Agency since 1944. We place emphasis on the cumulative rates of seawater intrusion as estimated in this study (Todd 1989 and others) for the Pressure 180-Foot and Pressure 400-Foot Aquifers. The rationale behind the use of cumulative rates is that the mapped front can occasionally jump ahead in a particular direction - as discussed in the Staal Gardner \& Dunne Inc. 1993 study. Such occasional changes in intruded areas are as likely due to addition of monitoring wells or data points landward of the intrusion front as augmented pumping of ground water in certain locations and thereby lowering the water levels. Although the expansion of intrusion area(s) of seawater is based on data, accelerated rates of encroachment may not be representative of the long term characteristics of seawater affected ground water. There is no conclusive data in support of the use of "periodically higher" seawater intrusion rates to estimate long-term movements of seawater in the Pressure area aquifers - hence this study stresses cumulative rates of seawater intrusion.

We believe that the rate of expansion of intruded seawater can accelerate in a certain direction due to increased pumping or short-term drops in ground water levels landward of the front during prolonged droughts. Likewise, a short-term reduction of intruding seawater can occur in wet years as ground water levels are correspondingly higher like in 1995 (Agency, 1997). There is however no information historically that suggests the overall expansion of intruded areas northward and southeastward have progressively increased. In fact, the aggregate rate of seawater intrusion has been at around 500 feet per year for the Pressure 180-Foot Aquifer and about 450 foot per year for the Pressure 400-Foot Aquifer.

According to the Ghyben-Herzberg principle, coastal aquifers with ground water levels below sea level will be intruded by denser seawater. This means that ground water in most of the East Side and Pressure Subareas west of the City of Salinas could have elevated levels of chloride exceeding $500 \mathrm{mg} / \mathrm{L}$ - as a result of seawater blending with fresh water. However, this is clearly not apparent as mapped intrusion fronts for both aquifers are located seaward of the City of Salinas, (Figures 3 and 4 ). The reason for this is because of the condition that ground water is

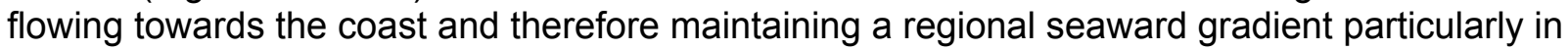
ground water upstream or east of the City of Salinas.

A more representative characterization of seawater intrusion is the use of empirical rate estimations which would be to evaluate landward increases in chloride levels with time. Specifically, we calculate rates of advances of the $500 \mathrm{mg} / \mathrm{L}$ chloride contours by dividing the maximum linear distance (feet) that the $500 \mathrm{mg} / \mathrm{L}$ chloride front has moved by the corresponding time period of advancement (years). 


\section{Kennedy/Jenks Consultants}

\section{Discussion}

\section{Regional Seawater Intrusion in the Pressure 180-Foot Aquifer}

Seawater intrusion has been known to occur in the Pressure 180-Foot Aquifer since the 1930s and has been documented beginning in 1946 (DWR, 1946). Historical tracking of the seawater intrusion fronts as depicted in'Figure 3'indicates that seawater has been migrating from along the coast line between Castroville in the north and Fort Ord in the south down the center of the Pressure Subarea. Todd (1989) estimated that the seawater intrusion front advanced landward at about 425 feet per year in the east-west and east-southeast directions and at about 514 feet per year (ft/yr) in the northwest-southeast direction.

Abundance of chloride data sampled in ground water wells from 1944 to the present has allowed this study to methodically define compartments or "corridors" of seawater movement and then calculate the variable rates of seawater movements within each corridor. Path-lines in 'Figure 3 depict seawater travel paths in six corridors and rates of seawater movement are calcūlated along each path. These corridors are not meant to distinguish hydrostratigraphic conditions but merely to serve as a spatial statistical means to: 1) calculate linear rates of travel; 2) compare and explain differences in rates; and 3) derive future-time-table for effectively "separate" seawater fronts to reach certain benchmark areas along their travel paths.

The general characteristics of the Pressure 180-Foot intrusion front markedly suggest that the northeast edge of the front parallels the facies change that borders the East Side ( $(\bar{F} \text { igure } 3)_{i}$ These fine-grained materials serve as a semipermeable barrier of flow from the Pressure to the East Side subareas. Ground water gradients in this area suggest flow from the Pressure to the East Side subarea. However, it is not suggested in 'Figure 3 'that the seawater edge as defined

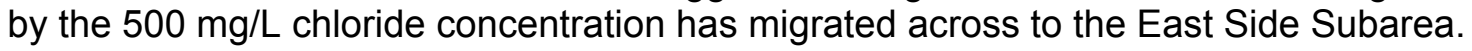
Moreover, it is unlikely that seawater will enter the transition area and the East Side any time soon based on the inferred rates of seawater advances (Path 2) and their less permeable aquifer properties.

The center lobes of the main seawater front exhibit bifurcation patterns (Path 4 area, írigure 3ij) as the successive chloride fronts (contours) intersect the elongate sliver of fine-grained fluvial materials through time. Specifically, the 1993, 1997, and 1999 lobes show slight retardation or contours are held back while the pointed lobes on either side of the lens of fine materials are slightly ahead. This characteristic of the main front will persist only in the area of the lens of fine material and that the 2001 and 2003 fronts will retain their more rounded "nose" pattern without the bifurcation.

The leading edge of the seawater intrusion front in this aquifer is 11,000 feet or about 2 miles from production wells (T14S, R3E, Sections 20 \& 29) in the City of Salinas. The main path of intrusion in the Pressure 180-Foot Aquifer indicates a rate of horizontal migration of $673 \mathrm{ft} / \mathrm{yr}$. We then predict that seawater will impact production wells in the City in about 14 to 16 years. 


\section{Kennedy/Jenks Consultants}

\section{Seawater Intrusion Through Natural Aquitard Leakage}

Historically, ground water elevations in the Pressure 180-Foot Aquifer have been higher (up to 40 plus feet higher) than the piezometric surface of the Pressure 400-Foot Aquifer (Todd, 1989; Harding ESE, 2001). Such a downward hydraulic gradient would bring about ground water movement from the Pressure 180-Foot Aquifer to the Pressure 400-Foot Aquifer. Interaquifer or cross-aquifer contamination is considered to a significant seawater encroachment threat to the current water quality of the Pressure 400-Foot Aquifer for this area. Thin to absent confining clay is observed in six of the seven cross-sections (all but G-G', 'Figure 1i).

Based on lithology depicted in the cross-sections and stratigraphic facies, we conclude that there are localized areas of aquitard thinning and absence. Data do not support the resemblance of spatially persistent paleo-channels that can be postulated as the genesis of scour marks and resulting in thin to absent clay layers. The most notable thinning of the Pressure 180/400-Foot Aquitard can be observed in the subsurface areas of the locations of intersections between cross-sections A-A' with E-E', F-F' and G-G' (see red dotted wells in 'Figure 3'and 4).' This particular area of aquitard thinning cannot be traced beyond well $14 \bar{S} / 0 \bar{B}-33 \bar{Q} 01$ on the northwest side of Cross-section G-G'.

Two probable scenarios of interaquifer flow is observed in this study; 1) spilling of degraded Pressure 180-Foot Aquifer ground water into the Pressure 400-Foot Aquifer ; and 2) slow downward movement of Pressure 180-Foot Aquifer ground water through sufficiently thin clay layers of the aquitard into the deeper Pressure 400-Foot Aquifer . Rates for either scenario are estimated to be from 0.1 to 0.25 foot per day dependent of the percentage of fine-grained materials within the interaquifer zones where the aquitard is either discontinuous or very thin. Hence we estimate that seawater reaching the Pressure 180-Foot Aquifer can impact the Pressure 400-Foot Aquifer ground water in one to four years over an interaquifer distance of 100 to 500 vertical feet.

\section{Regional Seawater Intrusion in the Pressure 400-Foot Aquifer}

The advancement of the seawater intrusion front in the Pressure 400-Foot Aquifer through 2001 is shown iniFigure 4. These delineations of intruded areas are also presented in Todd 1989 and in the Fort Örd and western Salinas Valley area in Harding ESE (2001). The area of the seawater intrusion and the shape of the front are more irregular than the Pressure 180-Foot Aquifer (Figure 3), although the migration rate of the Pressure 400-Foot Aquifer is slower but comparáblē(Sè- Table below and in Todd, 1989).

A distinct lobe of the seawater intrusion front in the Pressure 400-Foot Aquifer extends from Marina to wells 14S/2E-21N01, 14S/2E-21E01, and 14S/2E-21F02 (Path 4, Figure 4).

According to Harding ESE (2001), that lobe advanced nearly one mile between $\overline{1} \overline{9} \overline{9} \overline{7}$ and 1999 , which was surprisingly rapid (Path $4-1997$ to 1999).

The seawater intrusion front in the Pressure 180-Foot Aquifer reached this same area around 1997. The wells 14S/2E-21N01 and 14S/2E-21E01 were constructed in the mid 1990s, and are 


\section{Kennedy/Jenks Consultants}

constructed in the Pressure 400-Foot Aquifer and sealed through the Pressure 180-Foot Aquifer and higher zones, so Harding ESE (2001) does not consider that improper well construction led to cross-contamination of seawater from the Pressure 180-Foot Aquifer to the Pressure 400-Foot Aquifer.

These wells are located at the southwest end of Cross-Section C-C' (Figure 1), where a possible stratigraphic connection between the Pressure 180-Foot Aquifer and Pressure 400-Foot Aquifer was observed ('Figure 4, red dotted wells). Interaquifer communication may have been a factor in the rapid advance - one to four years.

The seawater intrusion rate as mapped by the chloride front for this same area in 2001 suggests that the advancement has slowed or halted (Figure 4); such that, no advancing distance was inferred for the years 2000 and 2001. The resultant aggregate seawater intrusion rate is about $578 \mathrm{ft} / \mathrm{yr}$. This rate is the highest inferred from the five seawater travel paths in this aquifer. It is slower than the maximum rate in the Pressure 180-Foot zone but comparable.

The seawater intrusion rate appears to "accelerate" along Path 3 in years 2000 and 2001 in Figure 4ias chloride data are contoured for Well 14S/02E-16G01. It is uncertain at the time of this study whether this is an artifact of an additional data point during the recent two years or actual accelerated movement of seawater in the northeast direction.

The leading edge of the seawater intrusion front in this aquifer is 28,000 feet or about 5 miles from production wells (T14S, R3E, Sections 20 \& 29) in the City of Salinas. It is unlikely that directly intruded seawater in the Pressure 400-Foot aquifer from its submarine outcrops will reach the City of Salinas any time soon - estimated 49 years travel time.

\section{Hydraulic Communication Between the Pressure and East Subareas}

The stratigraphic analysis in this study supports previous findings that the aquifer material makeup of the East Side Subarea - although heterogeneous and much less correlatable than the Pressure Subarea - are spatially consistent along the direction of the Pressure / East Side boundary. The consistency of stratigraphic facies are apparent in cross-sections C-C', D-D', E-E', F-F' and G-G' starting from and northeast of wells 14S/02E-02C03, 14S/03E-07A01, -09P03, -22D01, and well APN-003851028, respectively. These wells and transition zones northeast of them are again presented within the transition zone hatches for both aquifers in 'Figure 1' The hydraulic conductivities corresponding to these materials in our opinion are at least an order of magnitude lower than those of the aquifers in the Pressure Subarea.

We note that ground water flow direction is from the Pressure Subarea to the East Side Subarea east of the City of Salinas and along the transition zone (Agency 1997). The water levels in the Pressure 180-Foot Aquifer and the Shallow East Side Aquifer range from -20 to -70 feet MSL, respectively.

Water levels in the Pressure 400-Foot Aquifer and the Deep East Side Aquifer are between -20 feet to -60 feet MSL, respectively (Agency 1997). There is evidence in the stratigraphic 


\section{Kennedy/Jenks Consultants}

cross-sections of hydraulic communications between these subareas. These semipermeable and permeable zones of possible flow between the Pressure and East Side are depicted in Figures 3 'and 4 'along with the seawater intrusion fronts.

It is our opinion - with the above noted gradient of flow into the East Side - which denser seawater/freshwater mix will not readily flow into the East Side aquifers given the aquifer materials of much lesser permeabilities. The juxtaposed edges of the seawater intrusion front and the East Side boundary shown in'Figure 3 isupport this conclusion.

Lastly, the mostly fine-grained materials in stratigraphic facies depicted in the cross-sections C-C' through G-G' of the East Side Subarea do not support a significant component of vertical flow. The likelihood of downward movement of blended seawater/ground water in the transition zone and in the East Side Subarea is considered low. Hence, the postulated "return flow" scenario is unlikely. That is, seawater in the Pressure 180-Foot Aquifer flowing into the East Side aquifers, migrating downward in the later, and eventually spilling back out into the Pressure $400-$ Foot Aquifer is unlikely or the process would take a very long time.

\section{Conclusion}

\section{Pressure Subarea Hydrostratigraphy}

Interpretations of seven geologic cross-sections depict two general categories of sediments within the northern Salinas Valley fill: fine-grained aquitards and coarse-grained aquifers. Clays to gravelly clays are classified as aquitards and sands to sand-gravel mixtures are considered to be aquifer materials. Cross-section interpretations corroborate previous findings of the configuration and occurrences of a shallow ground water aquifer perched on top of or located within the Salinas Valley Aquitard. The cross section interpretations also verify that the tops of the Pressure 180-Foot and Pressure 400-Foot Aquifers are generally encountered at -100 feet and -300 feet mean sea level (MSL), respectively. The prominent clay layer, commonly referred to as the Pressure 180/400-Foot Aquitard, is also observed in most of the cross-sections constructed for this study.

The shapes of the sand bodies in the Pressure 180-Foot Aquifer appear to represent a fluvial depositional environment. Meaning, the lenticular shapes of the sand bodies observed in crosssections in the Pressure Subarea reflect deposition in a fluvial channel. In addition, the more laterally extensive sand units were formed by the fluvial channel meandering and shifting laterally through time.

In general, the Pressure 400-Foot Aquifer has a larger component of sand and gravel than the Pressure 180-Foot Aquifer, and the sand bodies are more laterally continuous than in the Pressure 180-Foot Aquifer. The more continuous nature of the Pressure 400-Foot Aquifer is interpreted to be the result of frequent meandering of the ancestral Salinas River across the river valley, which resulted in the widespread deposition of sand and gravel. This aquifer zone is more complex than the 180-Foot Aquifer with variable mix of coarse- and fine-grained deposits that become more variable in depth and thickness and more discontinuous from southeast to 


\section{Kennedy/Jenks Consultants}

northwest, i.e. in the downstream direction. This spatial transition is likely the remnants of a higher energy fluvial depositional environment near the present location of the City of Salinas to a lower energy environment toward the Monterey coast.

Localized areas where the Pressure 180/400-Foot Aquitard is thin or absent have been observed in cross-sections and mapped in plan view (Figures, $1,1,1$, this aquitard is absent and where possible direct communication can occur between the Pressure 180-Foot Aquifer and Pressure 400-Foot Aquifer is observed in portions of all crosssections except Cross-Section G-G'. Interaquifer impact is considered to be a significant seawater encroachment threat to the current water quality of the Pressure 400-Foot Aquifer for the northern Salinas Valley area.

The most notable area of discontinuities in the aquitard is in the vicinity of Township 14S, Range $3 \mathrm{E}$, Sections 20, 29, and 30. The feature that is observed in this area cannot be traced to beyond Cross-Sections D-D' and G-G'. In general, we conclude that there are localized areas of aquitard thinning and absence (Figures, $1,1,3,1$ and, 4 red dots). Data do not support the resemblance of a spatially continuous paleo-channel.

\section{East Side Subarea and Transition Zone Hydrostratigraphy}

The transition zone or boundary between the Pressure and East Side Subareas is defined in this study by the transition from predominantly fluvial facies to predominantly alluvial fan facies. By characterizing the sedimentary facies and stratigraphic architecture of the transition zone, we have filled in the missing link between the Pressure and East Side Subarea hydrogeology and developed models of the paleo-depositional environments.

The fluvially generated Pressure 180-Foot and Pressure 400-Foot Aquifers of the Pressure Subarea are not observed in the East Side Subarea. The sand and gravel beds of the East Side Subarea are generally thinner and less continuous than in the Pressure Subarea. This study corroborates previous investigations that the East Side stratigraphy does not correlate well between boreholes. We conclude and agree with other investigators that the gravel and sand deposits represent complex remnants of streams feeding the alluvial fans, which resulted in a complex record of sediment deposition and erosion.

Blue clay beds that form the principal aquicludes and aquitards in the Pressure Subarea are rarely observed within the East Side Subarea. Correlations completed in this study suggest that the blue clay spread through the northern Salinas Valley and onlapped the alluvial fans on the east side of the Valley.

The sedimentary facies characteristics of the East Side Subarea suggest that the wells in this area would be lower yielding and that the hydraulic conductivities are at least an order of magnitude lower than the sediments comprising the Pressure 180-Foot Aquifer zone of the Pressure Subarea. We also postulate that seawater intrusion would occur at a substantially slower rate, if at all, in the East Side Subarea than has been observed in the Pressure Subarea. 


\section{Kennedy/Jenks Consultants}

\section{Regional Seawater Intrusion}

The primary cause of seawater intrusion in the northern Salinas Valley area is that the aquifers are in direct hydraulic contact with the sea. Accordingly, we have evidence of submarine outcrops for both aquifers. The secondary cause of seawater mixing or intrusion in the fresh water aquifers is that ground water levels in both aquifers are below sea level with a developing landward ground water gradient recorded since the 1930s.

The Pressure 180-Foot Aquifer seawater intrusion front noticeably follows the trend of the coarse-grained fluvial facies, and is confined by the band of the less permeable fluvial facies '(Figure 3). These fine-grained fluvial deposits serve as a semipermeable barrier of flow from the Pressure to the East Side Subarea. Ground water gradients in this area suggest that flow occurs from the Pressure to the East Side Subarea. However, we conclude that the seawater intrusion front has not migrated across to the East Side Subarea. Moreover, it is unlikely that seawater will enter the transition zone or the East Side Subarea any time soon based on the inferred rates of seawater advances and the less permeable aquifer properties of the East Side sedimentary deposits.

The leading edge of the seawater front in the Pressure 400-Foot Aquifer is about five miles from production wells (T14S, R3E, Sections $20 \& 29$ ) in the City of Salinas. It is unlikely that seawater that has intruded directly from submarine outcrops into the Pressure 400-Foot Aquifer will reach the City of Salinas any time soon; the travel time is estimated to be 49 years, based on a rate of $578 \mathrm{ft} / \mathrm{yr}$. We do not anticipate abrupt accelerated advancement of seawater south of Castroville and in the Fort Ord area, where the two most prominent seawater intrusion fronts in this aquifer zone have been recorded to-date. We conclude that although regional seawater intrusion mechanism for the Pressure 400-Foot Aquifer is of importance for continued monitoring, it is more likely that in the City of Salinas this aquifer and its production wells will be impacted by interaquifer flow between the Pressure 180-Foot Aquifer and the Pressure 400-Foot Aquifer similar to that observed in the Fort Ord area.

\section{Recommendations}

These recommendations are made based on the analyses of hydrostratigraphic sections and the evaluation of seawater intrusion areas and rates of intrusion expansion. We also reviewed suggestions from previous studies and included those that are relevant to the objective of this study and in characterizing seawater intrusion in the northern Salinas valley. Recommendations listed are in no order of importance.

1. Perform detailed evaluations of water chemistry signature to distinguish the origin and mechanism of seawater / fresh water mix in ground water; i.e. regionally intruded seawater versus interaquifer contamination and well leakage. This can be done (as performed in Todd 1989) by use of Trilinear diagrams of cation and anion distributions at specific well locations. This should be done in additional to chloride spatial and temporal trend analyses. 


\section{Kennedy/Jenks Consultants}

2. Map vertical hydraulic gradients for the ground water data for the Pressure $180-$ Foot and 400 -Foot Aquifers. Changes in ground water gradient provide an indication of the degree of confinement of the lower water-bearing zone by the Pressure 180/400 Aquitard. This in turn can infer the spatial variation of thicknesses of the aquitard. This approach will depend on the availability of data and well completion records. These gradient maps should then be compared to hydrostratigraphic facies maps in this study.

3. Estimate the spatial distribution of ground water leakages (Darcy's flux) across the Pressure / East Side Subarea boundary

4. Map the distribution of interaquifer flow quantities

5. Estimate and map the quantity of well leakage where data are available.

6. Continue water quality sampling - specifically chloride and total dissolved solids - in both aquifers to aid in modeling the future pattern of seawater and to distinguish mechanisms of intrusion and seawater / fresh water mixing.

7. Use dual-density computer model to evaluate flow and seawater mixing with fresh water as part of overall water resources planning.

8. Continue updating the Agency WRAIMS database in terms of ground water quality, elevations, and lithologic information. WRAIMS should be used to update the lithologic cross-sections whenever new data are available for reevaluation of the area's hydrostratigraphy.

WRAIMS should be upgraded with a computerized hydrostratigraphic analysis tool to allow for more efficient review of cross-sections and ground water data. The most cost effective solution is to upgrade WRAIMS with a cross-section development tool as an extension to its GIS.

9. Continue to evaluate and refine the boundary between the Pressure and East Side Subareas based on water quality, hydrostratigraphic understandings, and updated interpretations of the depositional environment as reported in this study that makeup the present day Salinas Valley.

10. Construct a three-dimensional model based on the hydrostratigraphic analysis reported in this study. The amount of data used in this study and its findings merit the development of a solid 3-D model of: A) inferred permeabilities, B) lithology; and C) depiction of ground water quality and elevations. The best approach to accomplish this is to digitally parameterize (populate) a 3-D numerical matrix - based on correlations in cross-sections. This 3-D model (matrix) can be used to calculate (map) flows and quantify ground water volumes by aquifers or by compartments like those used in evaluating the seawater pathways in this report. 


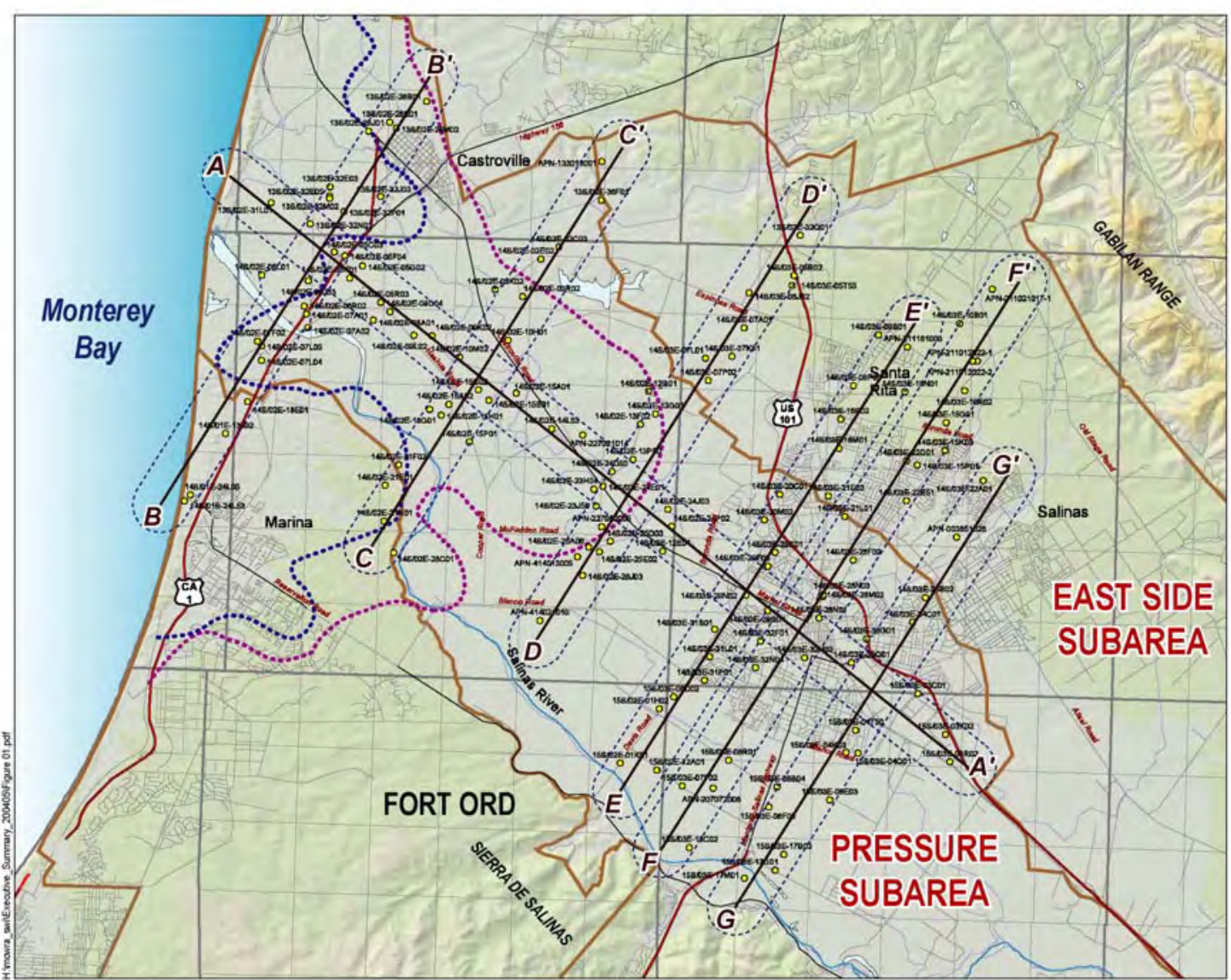

Figure 1. Pressure Sub-Area and East Side Sub-Area. Transition zones between fluvial facies and alluvial facies
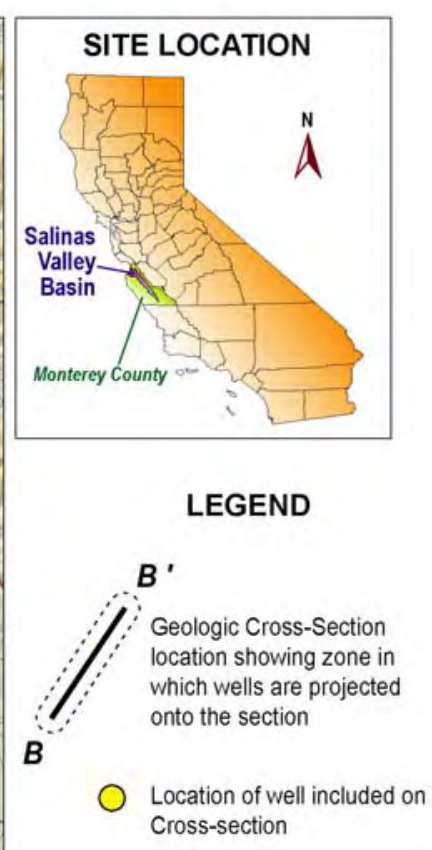

...... Seawater Intrusion Front - 2001 Pressure 400-Foot Aquifer

...... Seawater Intrusion Front - 2001 Pressure 180-Foot Aquifer

Boundary between Salinas Valley Hydrologic Subareas

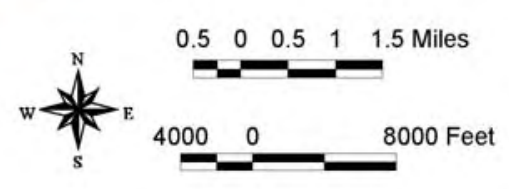




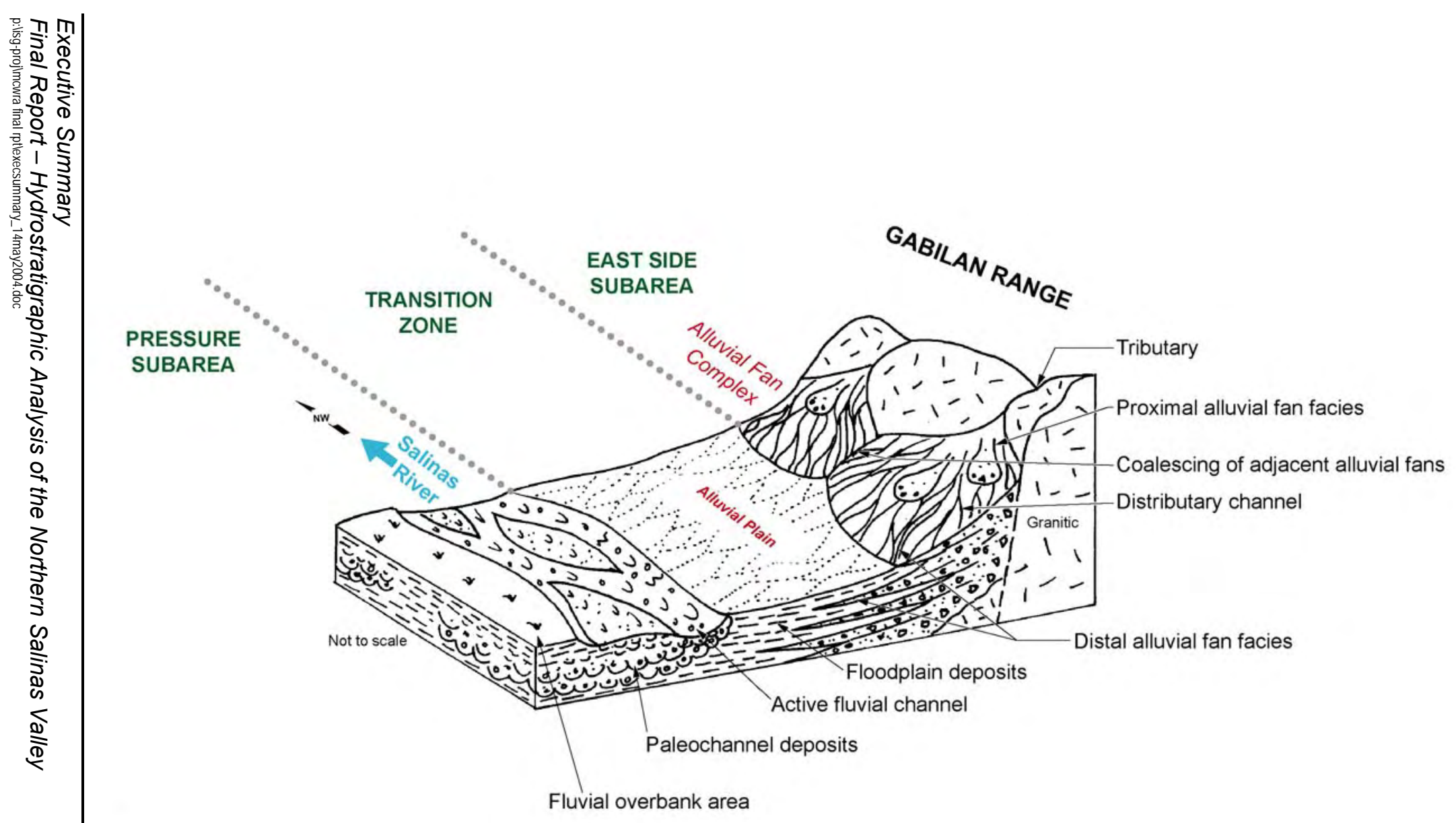

Figure 2. Generalized fluvial and alluvial fan facies of Northern Salinas Valley. 


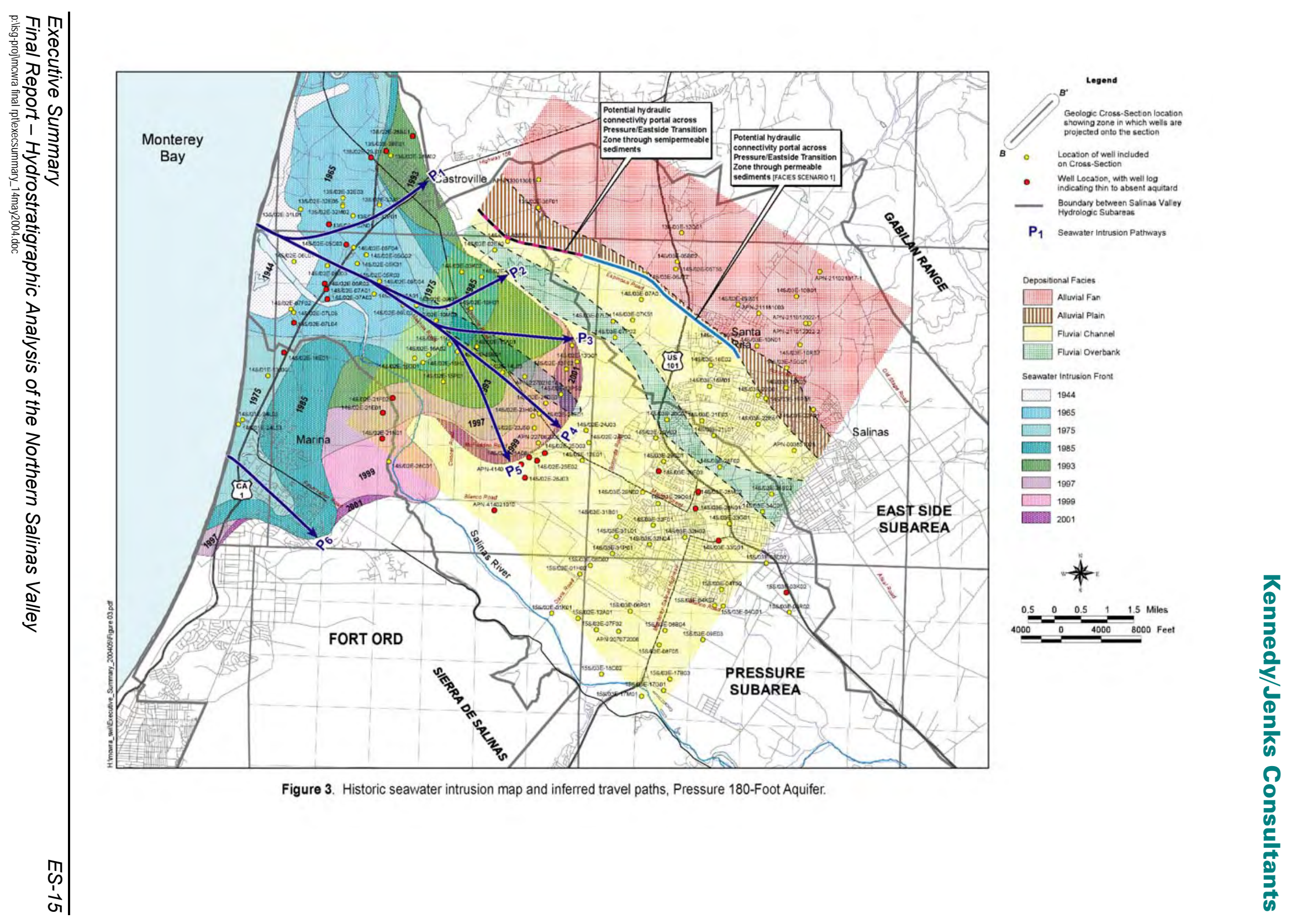



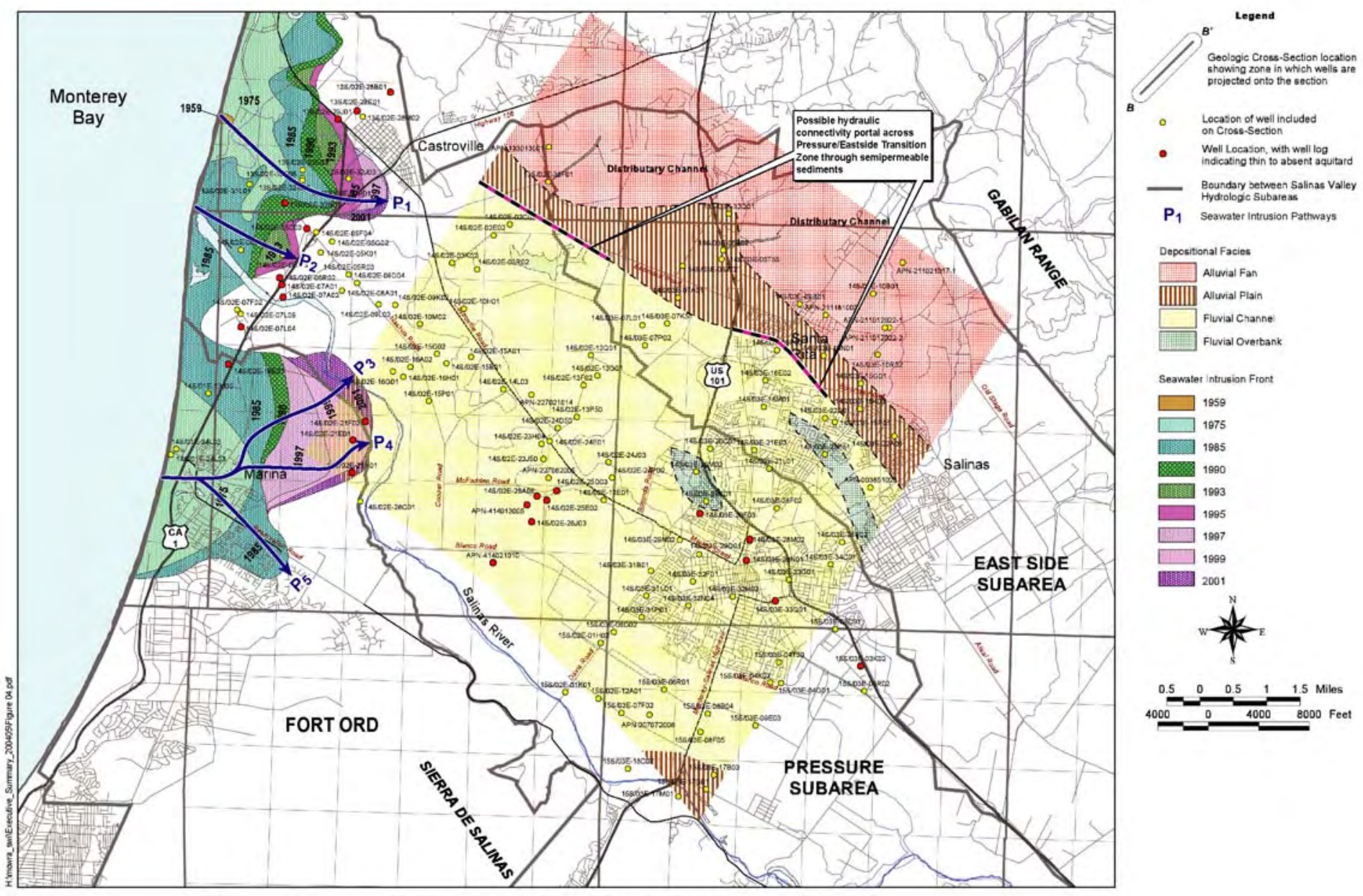

Depcestional Facies

IIIIIIIII Alwwial Palain

\begin{tabular}{l}
\hline Filvial Channe \\
\hline \hline Flwial Overtbank
\end{tabular}

Seawater intusion From

$\square 59$
$\square \quad 1975$

마맘 1985

1990

1993
$\square \quad 095$

$\square$
$\square$
$\square$

$\square 99$
$\square$

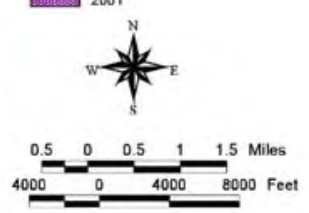


Kennedy/Jenks Consultants

\section{Section 1: Introduction}

This is a focused assessment of the hydrostratigraphy and updated interpretation of the ancestral depositional environment in areas beneath the City of Salinas to the Monterey Bay (Figure 1). These findings will assist in ongoing efforts to estimate rates of seawater intrusion in the aquifers beneath this area.

\section{$1.1 \quad$ Project Background and Study Goals}

The Monterey County Water Resources Agency (Agency), responsible for the management and planning of water resources within Monterey County, uses a network of wells to monitor ground water conditions in the Salinas Valley ground water basin. The Agency has documented progressive advancement of seawater into ground water zones and the understanding of the northern Salinas ground water basin hydrogeology have been documented by the Agency since the 1950s. Only in the later 1990s and recently have there been sufficient well logs, geophysical, and lithological data to support a three-dimensional (3-D) study of the interrelated ancestral fluvial and alluvial fan depositional environments that make up the present day ground water bearing zones. These zones are known as the Pressure 180-Foot Aquifer and the Pressure 400-Foot Aquifer. The study also includes a detailed analysis of the seawater intrusion pathways within these ground water bearing zones.

This report as intended by the Agency is the work of a focused study and update of the hydrogeologic interpretations to augment the ongoing assessment of rates of seawater intrusion into the Pressure 180-Foot Aquifer and the Pressure 400-Foot Aquifers. Specific goals in this study are:

- Examine the lithologic continuity of hydrostratigraphy in the Pressure and East Side subareas;

- Characterize the hydrostratigraphic nature of the transition zone between Pressure and East Side subareas;

- Provide detailed depiction of localized thinning and absence of clay sequences that facilitate hydraulic communication between the Pressure 180-Foot Aquifer and the Pressure 400-Foot Aquifer; and

- Estimate rates of seawater intrusion and the advancement of seawater encroachment towards the City of Salinas.

The occurrence of seawater intrusion into the Pressure 180-Foot Aquifer in the areas between the City of Salinas and the coast was first documented in 1933 by the State of California. Continued seawater intrusion to present day is largely attributed to overdraft of ground water from the Pressure 180-Foot Aquifer. Withdrawals from both the Pressure 180-Foot Aquifer and the Pressure 400-Foot Aquifer have lowered water levels below sea level. Seawater intrusion into the Pressure 400-Foot Aquifer has been slower and less extensive than in the overlying Pressure 180-Foot Aquifer because the Pressure 400-Foot Aquifer was not drawn upon until 


\section{Kennedy/Jenks Consultants}

water quality in the Pressure 180-Foot Aquifer had been significantly degraded. However, in recent studies, the integrity of the aquitard that separates the Pressure 180-Foot Aquifer and the Pressure 400-Foot Aquifer has been the subject of detailed hydrogeologic interpretations using new data and reinterpretations of previous results. This report examines evidence of localized thinning and absence of the clay layer that likely results in interaquifer migration or downward gradient flow of ground water and seawater from the Pressure 180-Foot Aquifer to the Pressure 400-Foot Aquifer.

\subsection{Scope of Work}

The scope of work authorized by the Agency is as follows:

Task 1 - Review of Literature and Preparation of Bibliography

Task 2 - Review of Well Logs and Available Cross-sections; Compilation of lithologic database and 3-D geographic information system.

Task 3 - Selection of Optimum Locations of Cross-sections; Construct lithologic cross-sections and perform hydrostratigraphic correlations

Task 4 - Results Discussion of Hydrostratigraphy of the Pressure and East Side Subareas

Task 5 - Results Discussion of Hydrostratigraphy of the Transition Zone between Pressure and East Side Subareas

Task 6 - Development of Seawater Intrusion Rates

Task 7 - Preparation of Final Report

\subsection{Approach}

Our approach in this study was to construct a 3-D hydrogeologic conceptual model of the northern Salinas Valley. With the use of a 3-D geographic information system (GIS) and a database of over 700 wells, we intend to present a comprehensive update of previous findings. This update will be based on previous and recently acquired lithologic data and will introduce three possible scenarios of the ancestral deposition processes that make up the present day hydrogeologic structure. The objective of this study is a focused assessment of the adjacent Pressure 180-Foot Aquifer and Pressure 400-Foot Aquifer. These aquifers span the uppermost 600 feet of sedimentary sequences and are part of the Valley Fill Deposits (Qvf) and the underlying Aromas/Paso Robles Formation (Qar).

Seven cross-sections and hydrogeologic maps were used to depict the hydrostratigraphic characteristics of the Pressure 180-Foot Aquifer and Pressure 400-Foot Aquifer and the hydrogeologic relationships, and the inferred hydraulic properties in the transition zone between the Pressure and East Side. The analysis of hydrostratigraphy, hydrogeologic conditions, and 


\section{Kennedy/Jenks Consultants}

ancestral deposition processes was performed with the goal of expanding the knowledge base to enhance the ability to assess the threat and estimate rates of seawater encroachment.

One cross-section (A-A') is oriented northwest-southeast, along the Salinas Valley axis, and six cross-sections (B-B' to G-G') are oriented southwest-northeast. The cross-sections identify changes in stratigraphy and permeability within and between the Pressure and East Side subareas. The differences in water levels between the Pressure Subarea and the East Side Subarea suggest that stratigraphy and permeability changes between the two subareas. Wells included in cross-sections are identified with state well identifications (township/range/section) with the exception of those that are currently identified with assessor's parcel number labels (APN labels). These wells have not been assigned state well identifications.

An equally important goal of the cross-sections is to identify areas of localized thinning and absence of confining layers, such as the blue clay sequences. Such areas are of particular interest in assessing localized downward flow of ground water. Interaquifer contamination is considered as considerable localized seawater encroachment threat to the current water quality in primarily the Pressure 400-Foot Aquifer for this area.

\subsection{Hydrostratigraphic Cross-Sections}

The cross-section locations are shown on Figure 2 and the cross-sections are included as Figure 3 through Figure 9. Cross-Section A-A' extends northwest to southeast and provides a longitudinal or axial profile rendition of the valley sediments. Cross-Sections B-B' through G-G' individually extend from southwest to northeast, parallel to each other and sub-perpendicular to Cross-Section A-A' and the axis of the Salinas River Valley.

The stratigraphy on the cross-sections is based on data from well logs provided in electronic format and on paper copies of logs provided by the Agency (Table 1). The lithologic entries on the paper logs were interpreted to conform to the GeoBase ${ }^{\mathrm{TM}}$ graphic system in use by the Agency; for example "sand and clay" on a driller's log was interpreted as "sand/clay" (i.e. interbedded sand and clay) for presentation on the cross-sections.

The lithology shown on the cross-sections is based on Water Well Drillers Reports (DWR-188 forms) filed by the well drillers with the State of California Department of Water Resources (DWR). In some cases the logs may be old, the depth resolution poor, or the lithologic distinction suspect. In other cases the drilling method is not conducive to accurate logging. The lithology shown on the well logs should not therefore be viewed as precise.

This study presents cross-sections that are positioned as straight lines (Figure 2) with lithology projected onto each section. Wells with available lithologic logs within 1,000 feet of a crosssection were subjected to be included for stratigraphic correlation. We have assess the regional and local attitudes of soil horizons and lithologic dip angles and concluded that attitudes of both are nearly horizontal in the easterly / westerly directions - along the axis of the Northern Salinas valley. Therefore, we have not corrected for dip angles in projecting lithologic unit depths onto cross-sections - i.e. no elevation corrections necessary. 


\subsection{Previous Studies}

Sixty-five documents spanning the time period from 1904 to 2001 were reviewed as background information, raw data resources, and relevant, up-to-date interpretations of the geology and hydrogeology of the northern Salinas Valley. These references are presented in bibliography form in Appendix B. Twenty references are cited in this report and they are presented in the references Section 10. Reviews of previous work are summarized in Section 2, "Background Hydrogeology." This section is extensive and intended as a reference for this study. 
Kennedy/Jenks Consultants

\section{Section 2: Background Hydrogeology}

This section presents the geographic and hydrologic setting of the northern Salinas Valley. The hydrologic subarea designations, stratigraphy, hydrostratigraphy, and depositional settings are introduced and discussed.

\subsection{Geographic and Hydrologic Settings}

The Salinas Valley Ground Water Basin is situated entirely within Monterey County, located along the central California coast approximately 100 miles south of San Francisco (Figure 1). The Salinas Valley is an elongate intermountain valley, extending from the northwest at the Monterey Bay to the southeast for about 80 miles inland. It is bounded by the Sierra De Salinas in the west and by the Gabilan and Diablo Ranges in the east. The valley ranges in width from about 14 miles in the north at the City of Salinas (i.e. this Study Area, Figure 1) to about 2 miles at its southeastern end.

The narrow basin encompasses about 561 square miles and is distinguished by four subareas as described by the California Department of Public Works, Division of Water Resources (DWR) in DWR Bulletin 52 (DWR, 1946). These subareas were defined based on sources of ground water recharge and the nature of the stratigraphy, and were depicted for analytical purposes only. DWR (1946) noted that these areas are not sub-basins, and that the subareas are hydrologically connected.

The Pressure, East Side, Forebay, and Upper Valley subareas are hydrologically and hydraulically connected. Recharge to ground water is from percolation from the Salinas River and its tributaries during and following the rainy season. Primary surface water features overlying and recharging the basin's ground water storage are the Salinas River, which runs the entire length of the ground water basin, and its tributaries. At the southeastern end of the basin, water from Nacimiento and San Antonio reservoirs is released into the Salinas River for recharge into the basin. Two subareas that are within this project study area - northern Salinas Valley - are shown in Figure 1 and briefly described in the following sections.

\subsection{Pressure and East Side Subareas}

The northern Salinas Valley is divided into two subareas, the Pressure Subarea to the west and the East Side Subarea to the east (Figure 1). The hydrogeology and ground water behavior in each subarea is markedly different due to different depositional environments and geology. Much work has been conducted in the Pressure Subarea and the hydrostratigraphy and depositional history is relatively well understood. Less work has been conducted in the East Side Subarea, however, and the stratigraphy is much more complex, more variable, and lacks well-to-well correlation compared to the Pressure Subarea. The transition zone between these subareas as part of this study area has not been extensively studied in the past. 


\section{Kennedy/Jenks Consultants}

\subsection{Stratigraphy of the Northern Salinas Valley}

Sections 2.3.1 to 2.3.4 describe briefly the stratigraphic units that are within the stratigraphic depths of this study - those include the Salinas Valley Aquitard (SVA) to the Pressure 400-Foot Aquifer - and they are presented from the youngest to oldest. Section 2.3.5 outlines the older and deeper geologic formations that underlie the Pressure 400-Foot Aquifer.

\subsubsection{Recent Alluvium}

Recent alluvium in the Salinas Valley includes the upper 10 to 75 feet of alluvium deposited by the Salinas River (DWR, 1973; Harding ESE, 2001). These deposits have low to moderate permeability and include perched ground water zones. The perched ground water zones in general have not been affected by seawater intrusion, but in some cases have been affected by percolate from agriculture (Harding ESE, 2001). DWR (1973) identifies approximately 20 feet of sandier material underlying the lower permeability zones as the base of the Recent Alluvium.

\subsubsection{Valley Fill}

This Pleistocene unit underlies the recent alluvium and is composed of alternating, interconnected, complex beds of fine-grained and coarser-grained estuarine and fluvial deposits. It includes the SVA, which overlies and confines the Pressure 180-Foot Aquifer. The Valley Fill ranges from approximately 25 feet to 100 feet thick (DWR, 1973; Harding ESE, 2001).

\subsubsection{Aromas Sand}

The Pleistocene Aromas Sand underlies the valley fill and consists mainly of cross-bedded sand with some clayey layers (Harding ESE, 2001). The lower Aromas Sand near the contact with the underlying Paso Robles Formation is commonly stained a distinct red or brownish color.

Previous reports also infer that the Aromas Sand is a continental deposit but these reports do not agree on the depositional origin. Harding ESE (2001) observes in one area of Marina / Fort Ord, cross bedding and grain size suggests that the Aromas Sand was deposited in eolian conditions, but elsewhere on the site, Harding ESE reports that angular granitic clasts in the basal Aromas Sand suggest a high-energy alluvial or alluvial fan depositional environment. Greene (1970) suggests deposition in a shoreline environment, and Greene (1977) and Dupre (1990) suggest an eolian depositional environment.

\subsubsection{Paso Robles Formation}

The middle to lower Pleistocene (Thorup, 1976) Paso Robles Formation consists of lenticular beds of sand, gravel, silt, and clay. Harding ESE (2001) indicates that in the Marina / Fort Ord area, the beds are laterally discontinuous and may indicate an alluvial fan or braided stream depositional environment; Thorup (1976) indicates the Paso Robles Formation was deposited by the ancestral Salinas River. Greene (1970) suggests that the formation is upper Pliocene to Pleistocene and includes alluvial fan, lake, and floodplain deposits. 


\section{Kennedy/Jenks Consultants}

\subsubsection{Older and Deeper Geologic Formations that Underlie the Pressure 400-Foot Aquifer}

\subsubsection{Purisima Formation}

The Pliocene Purisima Formation directly beneath the lower Paso Robles Formation is a shallow marine unit composed of intercalated siltstone, sandstone, conglomerate (Greene, 1977), clay, and shale (Harding ESE, 2001). In the Santa Cruz and Scotts Valley area (north of the study area), the Purisima Formation occurs in outcrop but in the Monterey Bay and Salinas Valley area the Purisima only occurs in the subsurface, where it is conformably overlain by the Paso Robles Formation (Greene, 1977; Harding ESE, 2001).

Thorup (1976) identified approximately 1,420 feet of Pliocene sediment in Well 14S/02E-22K01, including Purisima and Santa Margarita Formation sediments.

\subsubsection{Santa Margarita Formation}

The Upper Miocene to Pliocene Santa Margarita Formation consists of friable arkosic sandstone (Greene, 1977) deposited in shallow marine conditions (Harding ESE, 2001). It underlies the Purisima Formation, in the Seaside Basin and may directly underlie the Paso Robles Formation in areas where the Purisima Formation is absent (Greene, 1977). Thorup (1976) identified Pliocene material, including the Santa Margarita Formation, in Well 14S/02E-22K01.

\subsubsection{Monterey Formation}

The Monterey Formation is a Miocene-aged marine shale and mudstone (Green, 1970), generally composing the base of water-bearing sediments in the northern Salinas Valley area. Extensive exposures of the Monterey Formation occur in the hills south of the study area and clasts are commonly observed in fluvial sediments (Staal, Gardner, \& Dunne Inc., a.k.a. SGD 1993). Thorup (1976) encountered the Monterey formation at approximately 1,675 feet below ground surface in Well 14S/02E-22K01.

\section{$2.4 \quad$ Hydrostratigraphic Units}

\subsubsection{Shallow Aquifer}

Ground water in the Pressure subarea shallow aquifers overlies the SVA in some areas (MCFCWCD, 1960). These aquifers typically have low to moderate permeability and range up to 75 feet thick (DWR, 1973). The ground water is generally poor quality (MCFCWCD, 1960).

\subsubsection{Salinas Valley Aquitard}

The SVA is a series of blue or yellow sandy clay layers, with minor sand layers, overlying and confining the Pressure 180-Foot Aquifer. In the Salinas Valley, the SVA extends from approximately Monterey Bay south to Chualar (approximately 10 miles south of Salinas), and from Fort Ord east to an irregular contact at the Pressure Subarea/East Side Subarea boundary. In general, the thickness ranges from approximately 100 feet in the area west of 


\section{Kennedy/Jenks Consultants}

Salinas, thinning to approximately 25 feet near Salinas (DWR, 1973), and pinching out east of Salinas.

\subsubsection{Pressure 180-Foot Aquifer}

The uppermost laterally extensive aquifer in the northern Salinas Valley is known as the "180-Foot Aquifer" or the "Pressure 180-Foot Aquifer", based on the depth where it is typically encountered (DWR, 1946). DWR (1970) and DWR (1973) indicate that it ranges from 50 to 150 feet in thickness, with the top typically encountered between 100 and 150 feet below ground. The upper portion of the Pressure 180-Foot Aquifer is unconfined and the lower portion is confined by the SVA and is recharged where the SVA pinches out, e.g. the Forebay area, and is exposed on the floor of Monterey Bay (Todd, 1989). The Pressure 180-Foot Aquifer generally consists of hydraulically connected sand and gravel beds with intervening clay layers (Harding ESE, 2001; Greene, 1970).

The location of this aquifer within the stratigraphic framework of the Salinas Valley is variable and evidently spans more than one stratigraphic unit. DWR (1970) and DWR (1973) correlate this aquifer to lower valley terrace deposits and upper Aromas Sand; Leedshill-Herkenhoff, Inc. (1984) correlates the aquifer with the Paso Robles Formation; DWR (1973) and Harding ESE (2001) assign the Pressure 180-Foot Aquifer to Valley Fill; and Greene (1970) places it in the lower Valley Fill and upper Aromas Sands.

\subsubsection{Pressure 180/400-Foot Aquitard}

The Pressure 180-Foot Aquifer and Pressure 400-Foot Aquifer are separated by a zone of clay, or clay and sand layers (MCFCWCD, 1960) referred to as the Pressure 180/ 400-Foot Aquitard. This barrier is widespread in the Salinas Valley basin and varies in thickness and quality from thick layers of blue clay to thin layers of brown clay (MCFCWCD, 1960).

Variability in thickness and quality of the Pressure 180/400-Foot Aquitard and the existence of possible gaps in the aquitard has been documented. MCFCWCD (1960) describes two small "holes" in the aquitard, one under the Salinas River near Blanco and another under the old Salinas River bed near the coast. The Pressure 180-Foot Aquifer and the Pressure 400-Foot Aquifer also appear to be interconnected in places between Salinas and Chualar (approximately 10 miles south of Salinas) and south of Chualar (MCFCWCD, 1960). Brown (1986) describes the aquitard as generally lenticular in shape and discontinuous in places, notably near the mouth of the Salinas River and near Fort Ord. Todd (1989) indicates several areas between Castroville and the coast where the aquitard is thin or absent.

\subsubsection{Pressure 400-Foot Aquifer}

The areally extensive layer of sand and gravel typically encountered between 270 and 470 feet below ground surface is referred to as the "400-Foot" or the "Pressure 400-Foot Aquifer". The depth to the top of the aquifer, the thickness of the aquifer, and the degree of complex interbedding with clay layers is quite variable between wells (Thorup, 1976). DWR (1970) and DWR (1973) indicate that near Salinas the aquifer consists of a single thick permeable bed approximately 200 feet thick, which divides into two 25 -foot thick sandy beds and one 100 -foot 


\section{Kennedy/Jenks Consultants}

thick sandy bed, separated from each other by clay layers, northwest toward Castroville. DWR (1970) and DWR (1973) indicate that in some areas, uppermost beds of this aquifer merge and interfinger with lower beds of the Pressure 180-Foot Aquifer.

In wells drilled near the Pressure/East Side boundary, SGD (1993) notes the sand layers contain fragments of shale and porcelaneous chert sand and gravel derived from the Monterey Formation (Section 2.3.5.3). Because the Monterey Formation is exposed at the surface south of Salinas (upstream) and not in the hills near Salinas, the presence of these rock fragments indicates that the sediments were deposited in a fluvial environment. The clay beds separating individual sand layers are blue or brown and may contain shell fragments (SGD, 1993).

DWR (1970) and DWR (1973) suggest that the upper portion of the Pressure 400-Foot Aquifer correlates to the Aromas Sand and the lower portion correlates to the Paso Robles Formation. Thorup (1976) correlates this aquifer with the Paso Robles Formation. Harding ESE (2001) indicates that recharge to the Pressure 400-Foot Aquifer is in the Arroyo Seco area; Thorup (1976) indicates that recharge to the Paso Robles Formation is provided by infiltration from the Salinas River in the King City area, infiltration from the Arroyo Seco River in the Arroyo Seco Cone area, and from precipitation runoff infiltration along the eastern edge of the Sierra de Salinas (Section 2.1).

\subsubsection{Pressure 400-Foot/Pressure Deep Aquitard}

The term Pressure Deep Aquifer includes the following aquifers: the 800-Foot Aquifer, 900-Foot Aquifer, 1,000-Foot Aquifer, and the 1,500-Foot Aquifer (Harding ESE, 2001). Thorup (1976) includes these aquifers in the Paso Robles Formation. The two aquifers are separated by an aquitard that can be several hundred feet thick.

\subsection{Depositional Environments of the Pressure and East Side Subareas}

The hydrostratigraphy of the upper 500 feet of the Pressure Subarea reflects the effects of the repeated fluctuation of sea level resulting from climatic changes in the Quaternary (Tinsley, 1975; Greene, 1977; SGD, 1993). The repeated cycle of sea level rise and fall, and the alternating periods of estuarine and fluvial deposition have created the sequence of aquitards and aquifers.

Tinsley (1975) relates the cyclic deposition to marine transgressions and regressions associated with glacio-eustatic sea level fluctuations. In relating the elevations of the aquifers, the sea level elevations during glaciation periods, the rates of sedimentation, and the rates of sea level changes, he demonstrated that the stratigraphy could be a product of marine transgressions and regressions depositional processes during the Wisconsin-age glaciation. Tinsley (1975) argues that a fall in sea level during glaciation resulted in extensive higher-energy, coarsergrained fluvial deposits as the base level was lowered and the river system incised the valley fill. $\mathrm{He}$ also argued that the rate of sea level rise during glacial melting periods was faster than the sedimentation rate in the northern Salinas Valley, resulting in the "drowning" the Salinas River Valley. This created lower-energy estuarine depositional environments similar to the presentday Elkhorn Slough, leading to the deposition of fine-grained aquitards. 


\section{Kennedy/Jenks Consultants}

Based on foraminiferal assemblages and the analysis of these glacial-related sea level changes, Tinsley (1975) concludes that the "blue clay" deposits (such as those within the SVA and those within the Pressure 180/400-Foot Aquitard) are likely estuarine deposits associated with these marine transgressions. Depositional environments and their relation to depositional facies are described more fully in Sections 4 and 5. 


\section{Section 3: Discussion - Pressure Subarea Hydrogeology}

This section discusses the geologic setting and hydrostratigraphy of the Pressure Subarea. A brief description of the inferred depositional genesis and how they were defined in this study for the purpose of correlating the northern Salinas Valley stratigraphy is also presented.

\subsection{Pressure Subarea Hydrostratigraphy}

The hydrostratigraphic discussion of the Pressure Subarea is based on previous work and on the cross-sections developed for this study. The cross-section interpretations depict two general categories of sediments within the northern Salinas Valley fill: fine-grained aquitards and coarse-grained aquifers:

- Clays, sandy clays, and gravelly clays are shown as aquitards;

- Sands, gravels, and sand-gravel mixtures are shown as aquifers; and lastly

- Sediments logged as gravel/clay, sand/clay, and sand/gravel/clay are interpreted to consist of interbedded coarse- and fine-grained deposits and are included with aquifer materials.

\subsubsection{Shallow Ground Water Aquifer}

A shallow ground water aquifer perched on top of or located within the SVA can be observed on most of the cross-sections. Scattered, thin, laterally discontinuous sandy layers are common, rarely up to 100 feet thick but typically much less. In Cross-Section G-G' (Figure 9), a laterally extensive but discontinuous sand unit extends from approximately 50 feet above mean sea level (MSL) to -50 feet MSL. This uppermost ground water bearing zone is referred to as the Upper Pressure 180-Foot Aquifer in the Fort Ord area (see also Section 3.1.3).

\subsubsection{Salinas Valley Aquitard}

The SVA appears on all of the cross-sections, typically extending from the ground surface to approximately -100 to -150 feet MSL. In Cross-Section B-B', the SVA apparently dips to the south and is covered by dune sands to the southwest. In Cross-Section C-C' the SVA also apparently is covered by more recent deposits to the southwest (sands recorded in well logs, not labeled on cross-section).

The SVA can be seen to thin and pinch out near the Pressure Subarea/East Side Subarea boundary in Cross-Sections D-D', E-E', and F-F'. The Pressure Subarea/East Side Subarea boundary is roughly the demarcation of what we infer to as the transition zone between fluvial and alluvial fan facies and they are discussed in Sections 4 and 5.

In Cross-Section G-G', SVA apparently thins and pinches out to the southwest but clay extends to the northeast side of the cross-section, across the Pressure/East Side (subarea) boundary. 


\section{Kennedy/Jenks Consultants}

This likely represents commingling of the SVA and distal clays associated with the alluvial fan facies.

Cross-Sections A-A' and G-G' suggest the presence of two possible windows or gaps in the SVA. In Cross-Section A-A', the clay is absent between wells APN 227021014 and 142/2E$23 \mathrm{H} 04$, near the intersection of Cross-Section A-A' and Cross-Section D-D'. In Cross-Section G-G', the SVA is apparently absent in well 15S/3E-04T50 (near distance marker 15000). The absence of SVA may create locally unconfined or partially confined conditions in the Pressure 180-Foot Aquifer.

\subsubsection{Pressure 180-Foot Aquifer}

The sand bodies in the Pressure 180-Foot Aquifer are predominantly sand and gravel deposits with subordinate sand/clay and gravel/clay components.

The depth and thickness of the Pressure 180-Foot Aquifer are variable, but generally the top is encountered at about -100 feet MSL, increasing in depth slightly from southeast near Salinas to the northwest near the ocean. Individual sand bodies within the aquifer are typically 100 to 150 feet thick, although they range from less than 50 feet thick to greater than 200 feet thick where the Pressure 180-Foot Aquifer and Pressure 400-Foot Aquifer appear to be in contact (see Section 3.1.4).

The shapes of the sand bodies in the Pressure 180-Foot Aquifer appear to reflect their fluvial depositional origin. In Cross-Section C-C' and Cross-Section D-D' especially, the lenticular shape of the sand bodies southwest of the East Side reflects deposition in a fluvial channel. The more laterally extensive sand units were formed by the fluvial channel migrating and shifting laterally through time.

This permeable zone is sometimes referred to as the Pressure Lower 180-Foot Aquifer, which can be considered a confined system beneath the SVA. The Pressure Upper 180-Foot Aquifer is sometimes called the uppermost-perched zone or the Shallow Ground Water aquifer (see Section 3.1.1).

\subsubsection{Pressure 180/400-Foot Aquitard}

The clay aquitard separating the Pressure 180-Foot Aquifer and Pressure 400-Foot Aquifer (the Pressure 180/400-Foot Aquitard) varies in composition, depth, and thickness, and may be absent in some areas. The Pressure 180/400-Foot Aquitard is rarely as much as 200 to 250 feet thick (see well 14S/2E-12E01 at distance marker 40,000 on Cross-Section A-A'), and more commonly 50 to 100 feet thick. Several well logs located in the southeast part of the study area (see Cross-Sections G-G' and A-A') show the distinct blue clay, however over most of the area the blue clay is uncommon and the aquitard is composed mainly of sandy clay or brown clay.

\subsubsection{Absence of Confining Clay Unit}

As observed in previous reports (e.g. Todd, 1989) and noted in this study, there are places in the northern Salinas Valley where the Pressure 180/400-Foot Aquitard is thin or absent. Locations of wells with the absence of the aquitard are depicted with red dots in Figure 10. 


\section{Kennedy/Jenks Consultants}

Possible direct communication between the Pressure 180-Foot Aquifer and Pressure 400-Foot Aquifer where this aquitard is absent can be observed on every cross-section except CrossSection G-G'. The areas of potential hydraulic communication are discussed below.

- $\quad$ Northwest part of Cross-Section A-A' and Cross-Section B-B':

On these two cross-sections, possible communication between the Pressure 180-Foot Aquifer and Pressure 400-Foot Aquifer can be observed in approximately seven well logs from just west of the Salinas River channel to east of Castroville. Possible communication between the aquifers is suggested by several observations:

- A long sequence of sand and gravel without an intervening clay in Cross-Section B-B' (e.g. 14S/2E-18E01 near distance marker 10,000);

- A mix of clay and either sand or gravel (GeoBase ${ }^{\mathrm{TM}}$ symbols sand/clay or sand/gravel/clay) but without a distinct clay layer in Cross-Section B-B' (e.g. 14S/2E06J03 near distance marker 18000), possibly reflecting interbedded clay and sand or clay and gravel;

- Thin clay layers that cannot confidently be correlated to other wells in Cross-Section B-B' (e.g. 13S/2E-28M02 to 13S/2E-29J01 near distance marker 30,000).

Todd (1989) also noted that the Pressure 180/400-Foot Aquitard is thin or absent near Cross-Section B-B'. As shown on'Figure 10, several of the wells where interaquifer communication may exist are located within the Pressure 400-Foot Aquifer seawater intrusion front; it is uncertain if interaquifer communication was a factor in the seawater intrusion front movement in this area.

- Cross-Section C-C':

On the southwest side of Cross-Section C-C', southwest of the Salinas River, the clay separating the Pressure 180-Foot Aquifer and Pressure 400-Foot Aquifer appears to exist, but is thin and correlation of this clay between wells 14S/2E-21N01 and 14S/2E-21E01 (between distance marker 2000 and distance marker 5000) is tenuous. The 2001 seawater intrusion front in the Pressure 400-Foot Aquifer makes a distinct eastward extension from Marina to this part of Cross-Section C-C' and nearly matches the seawater intrusion front in the Pressure 180-Foot Aquifer. It is possible that communication between the Pressure $180-$ Foot Aquifer and Pressure 400-Foot Aquifer in this area influenced the seawater intrusion front migration (see Sections 6.4 and 6.5).

\section{- Cross-Section D-D':}

Similar to Cross-Section C-C', the Pressure 180/400-Foot Aquitard is thin or absent toward the southwest side of the cross-section near wells 14S/2E-25D03 and 14S/2E-26J03 (between distance marker 5000 and distance marker 10,000). Thin clay layers are shown in the log for APN-14021010 (near distance marker 1500) but it is unknown if these layers extend northeast towards 14S/2E-26J03. These wells are located near the front of the 2001 seawater intrusion front in the Pressure 180-Foot Aquifer. 


\section{Kennedy/Jenks Consultants}

- Cross-Section E-E', Cross-Section F-F', and nearby areas of Cross-Section A-A':

In the central Pressure Subarea near the intersection of Cross-Section E-E' and CrossSection F-F' with Cross-Section A-A', sand units of the Pressure 180-Foot Aquifer and Pressure 400-Foot Aquifer appear to be in communication in a feature that may represent stacked fluvial channel deposits (Well 14S/2E-29N02 to Well 14S/2E-F03, area between distance marker 15000 and 20,000) on Cross-Section E-E' and Well 14S/3E-28M02 (near distance marker 22000) on Cross-Section F-F'. Here, the bottom of the Pressure 180-Foot Aquifer is slightly deeper than typical and where intervening clay is absent, resulting in a thick succession of sand and gravel from depths of approximately -100 feet MSL to -400 feet MSL. Cross-Section A-A' in this area (drawn generally parallel to the former fluvial channel) also suggests that clay layers are somewhat laterally discontinuous.

This paleo-channel like depositional feature cannot be traced to Cross-Section G-G' (where the Pressure 180-Foot Aquifer and Pressure 400-Foot Aquifer appear to be distinct) nor to Cross-Section D-D', although in Cross-Section D-D' the separation between the aquifers is thin.

\subsubsection{Pressure 400-Foot Aquifer}

The sand bodies in the Pressure 400-Foot Aquifer consist mainly of sand and gravel with a subordinate amount of sand and clay or gravel and clay mixtures. In general, the Pressure 400 -Foot Aquifer has a larger component of sand and clay or gravel and clay mixtures compared to the Pressure 180-Foot Aquifer.

The top of the Pressure 400-Foot Aquifer is typically encountered at -300 to -350 feet MSL. The thickness of this aquifer is variable but typical sand beds are 50 to 100 feet thick and can be up to more than 200 feet thick. The sand beds are especially thick in areas where the Pressure 180-Foot Aquifer and the Pressure 400-Foot Aquifer are possibly conjoined.

The Pressure 400-Foot Aquifer zone consists of a complex and variable mix of coarse- and finegrained deposits. In general, these layers become more variable in depth and thickness and more discontinuous from southeast to northwest, i.e. in the downstream direction. This variability is markedly characteristic by comparing Cross-Section G-G' with Cross-Section C-C' and Cross-Section B-B', and can be observed on Cross-Section A-A'. This transition may be due to the transition from a higher energy fluvial depositional environment near the present location of the City of Salinas to a lower energy environment toward the Monterey coast.

\subsubsection{Locations of the Thickest Sand Zones}

The thickest portion of this aquifer can be traced in all the northeast-southwest cross-sections, where the thicknesses of the sand zones are somewhat evenly distributed, unlike the Pressure 180-Foot Aquifer. In the southeast part of the study area, the thicker sand bodies are located in the central parts of Cross-Sections G-G', F-F', and E-E' at about the crossings of A-A'. In CrossSections D-D' and C-C', the thicker sand deposits are located on the southwest side of the cross-sections, i.e. the southwest part of the Pressure Subarea. 


\section{Kennedy/Jenks Consultants}

In Cross-Section B-B' located in the northwest part of the study area, thick sand deposits are more prevalent than those in sections located further southwest (C-C' through G-G'). Unlike the other sections, the East Side Subarea is not encountered in this cross-section. Thick sections of sand are observed in the central part of the cross-section and in the northeastern end near Castroville, i.e. the central and eastern portions of the Pressure Subarea, respectively.

The thicker sections of the Pressure 400-Foot Aquifer located in the southwest also coincide with areas where the Pressure 180/400-Foot Aquitard is thin or absent (see Figure 10 and the discussion in Section 3.1.4.1). Lastly, Cross-Section A-A' is located along the depositional axis, so that it shows the sand/clay sequences near the center of the inferred ancestral channel. This channel can be thought of as a high-energy fluvial depositional environment in the southeastern section and estuarine in its northwestern section toward Monterey Bay.

\subsubsection{Pressure 400-Foot/Pressure Deep Aquitard}

The clay layers separating the Pressure 400-Foot Aquifer and the Pressure Deep Aquifer can be observed in Cross-Sections B-B', F-F', and G-G'. In Cross-Section B-B', the aquitard encountered in well 14S/2E-18E01 (near distance marker 10,000) extends approximately 50 feet below the Pressure 400-Foot Aquifer to a gravelly layer approximately 150 feet thick; the aquitard extends approximately 650 feet to the next sandy layer. In well 14S/2E-06L01 (near distance marker 17000), the aquitard extends approximately 750 feet below the Pressure 400-Foot Aquifer to the next sandy layer. In Cross-section F-F' and Cross-Section G-G', the aquitard is approximately 100 to 120 feet thick.

\subsection{Ground Water Elevations}

Ground water elevations are monitored regularly by the Agency in the Salinas Valley in monitoring wells and agricultural production wells. Historical ground water elevations reflect drawdown and depressed ground water elevations during the summer irrigation season and recovery of ground water elevations during the winter.

Construction of ground water elevation contour maps is complex and difficult because many wells are constructed with long intake screens spanning both the Pressure 180-Foot Aquifer and Pressure 400-Foot Aquifer, and many wells are located in or near the border with the East Side Subarea, where the transition between the subareas is complex. Ground water elevation contour maps used in this study are therefore not included in this report.

Data collected in 1999 from the Fort Ord area and the western Salinas Valley are presented as ground water elevation contours in the Harding ESE 2001 report. Those data indicate that ground water elevations in the Pressure 180-Foot Aquifer and Pressure 400-Foot Aquifer were below sea level, with elevations in the Pressure 180-Foot Aquifer as low as -20.7 feet MSL near the Salinas River and elevations in the Pressure 400-Foot Aquifer as low as -51.4 feet MSL east of the Salinas River (near the intersection of Cross-Section A-A' and Cross-Section C-C'). The lower ground water elevations in the Pressure 400-Foot Aquifer indicate that a vertical hydraulic gradient downward from the Pressure 180-Foot Aquifer to the Pressure 400-Foot Aquifer exists. 


\section{Kennedy/Jenks Consultants}

The sub-sea level elevations in both the Pressure 180-Foot Aquifer and Pressure 400-Foot Aquifer have been consistent for many years, as has been the difference in elevations between the two aquifers (Todd, 1989 and Harding ESE, 2001). Todd (1989) and Harding ESE (2001) suggest that this trend indicates that although the aquitard between the two aquifers may be discontinuous in places, the aquitard is sufficient to consistently support a vertical head difference. The consistent sub-sea level ground water elevations in both aquifers create a situation that promotes continued seawater intrusion. 


\section{Section 4: Discussion - East Side Subarea Hydrogeology}

This section discusses the geologic setting and hydrostratigraphy of the East Side Subarea. A description of the depositional facies and how they were defined in this study for the purpose of correlating the northern Salinas Valley stratigraphy is also presented. This section contains a brief discussion of the East Side Subarea ground water.

\subsection{East Side Subarea Geologic Setting}

The East Side Subarea extends along the east side of the northern Salinas Valley, from approximately Santa Rita (approximately three miles north of Salinas) to Gonzales (approximately 16 miles south of Salinas), and is generally bounded by the foothills of the Gabilan Range on the northeast and Highway 101 on the southwest (Figure 1). The East Side Subarea is presently characterized by a series of connected alluvial fans that are built up by small streams draining the west side of the Gabilan Range, creating a sloping, fan-shaped topography that is visible today.

The East Side Subarea was originally defined by DWR (1946) as one of the four areas of the Salinas Valley that were designated according to their hydrologic properties and recharge areas. The East Side was defined as the area bounded by the Pressure Subarea on the west and the Forebay Subarea on the south, containing unconfined ground water that was recharged (under appropriate pumping conditions) by streams draining the Gabilan Range and directly from precipitation during wet years. The East Side Subarea was also defined in MCFCWCD (1960) as "... a region that does not have a continuous area wide aquifer nor a continuous good quality aquiclude."

\subsection{East Side Subarea Hydrostratigraphy}

The Quaternary stratigraphy of the East Side Subarea generally consists of a poorly bedded sequence of gravel, sand, silt, sandy and gravelly clay, and clay. Typical East Side sediments include red, brown, and yellow clay, gravelly or sandy clay, as well as "seepage" (defined by well drillers as a sandy and gravelly clay type of material through which water seeps slowly; MCFCWCD, 1960). On the outwash slopes of the present-day alluvial fans in the East Side Subarea, red and yellow clays are currently being formed in discontinuous lenses by the decomposition of alluvial gravels (MCFCWCD, 1968). Decomposed granite is also characteristic of the East Side Subarea sediments, reflecting the granitic provenance of the Gabilan Range (Figure 11). These Quaternary sediments, interpreted as alluvial fan deposits, grade into and interfinger with fluvial sediments deposited by the ancient Salinas River that flowed northwestward into the Monterey Bay.

The sand and gravel beds of the East Side Subarea are generally thinner and less continuous than in the Pressure Subarea, and generally do not correlate well between boreholes. The East Side Subarea is difficult to correlate due to the following stratigraphic characteristics:

- Relatively thin-bedded nature of the gravel and sand;

- Discontinuity of beds in both the lateral and down-dip direction; and 


\section{Kennedy/Jenks Consultants}

- Complex erosional nature of streams feeding the alluvial fans, which results in a complex record of sediment deposition.

Blue clay beds form the principal aquicludes and aquitards in the Pressure Subarea are rare within the East Side Subarea. The blue clays are highly organic, unoxidized, and contain molluscan and foraminiferal faunal assemblages that are indicative of shallow marine to brackish water estuarine environments (Tinsley, 1975). Stratigraphic correlations completed in this study suggest that the blue clay spread through the northern Salinas Valley and onlapped the alluvial fans on the east side of the northern Salinas Valley. A blue clay bed onlaps and pinches out onto alluvial fan facies in the East Side Subarea on Cross-Section D-D' (Figure 6, distance marker 31,000) and Cross-Section F-F' (Figure 8, distance marker 40,000). The depositional evolution of blue clay beds in the East Side Subarea is discussed in Sections 5.2.1 and 5.3.2.

The fluvially generated Pressure 180-Foot and Pressure 400-Foot aquifers of the Pressure Subarea are not observed in the East Side Subarea. However, the East Side sediments can be divided into zones that are generally time-stratigraphically equivalent to the Pressure 180-Foot and Pressure 400-Foot Aquifers (dashed lines designate these zones on the stratigraphic crosssections, Figures 3 through 9). The designation of these stratigraphic zones was utilized for analyzing the lateral connectivity of the aquifers between the Pressure and East Side subareas, and for determining the distribution of depositional facies during the 180-Foot Aquifer "time" and the 400-Foot Aquifer "time".

\subsection{Depositional Facies in the Pressure/East Side Transition Zone}

This section provides a brief overview of the sedimentary depositional facies encountered in the transition zone between the Pressure Subarea and the East Side Subarea. This section also describes how these facies were identified in the stratigraphic correlations completed as part of this study.

\subsubsection{Alluvial Fan Facies}

Alluvial fans form at the base of a mountain front where emerging mountain streams transport and deposit sediments (Figure 11). As distributary streams and channels that drain the mountains shift laterally through time, a fan-shaped sedimentary deposit (alluvial fan) is formed. Depositionally down dip from the mountain front, alluvial fans commonly grade into a fluvial system flowing longitudinally down a valley oriented parallel to the adjacent mountain range. Alluvial fans can also build out into estuarine environments (as well as marine, lacustrine, and eolian environments).

Alluvial fan deposits commonly consist of a mixture of partly sorted streamflow deposits and unsorted debris-flow and mudflow deposits. A rapid downfan decrease in clast size and overall sediment grain size is also characteristic of alluvial fans. Sediments within a fan complex are generally oxidized, resulting in the characteristic sediment colors of red, brown, orange, and yellow. 


\section{Kennedy/Jenks Consultants}

The internal stratigraphic geometry of alluvial fan systems can be complex. Fans can prograde rapidly following uplift of the source area, resulting in proximal facies overlying more distal facies. Lateral shifting of distributary channels within the fans results in the coalescing of adjacent alluvial fans (Figure 11), creating complex facies relationships. Where the distal facies of the alluvial fan interfingers with a fluvial system (Figure 11), there may be complex facies relationships recording both depositional and erosional activities by both the alluvial fan system and the fluvial system.

Alluvial fans can be divided into a proximal fan facies, deposited near the sediment source area (e.g., along the front of a mountain range), and a distal alluvial fan or alluvial plain facies, deposited more distally from the source and down dip from the proximal facies (Figure 11).

\subsubsection{Proximal Alluvial Fan Facies}

Proximal alluvial fan facies commonly consist of poorly sorted and generally angular clasts, reflecting the proximity to the sediment source area. In the stratigraphic correlations completed as part of this study, the proximal alluvial fan facies were distinguished by the predominance of coarse-grained deposits (e.g., coarse gravel and sand). In addition, the thickness of these coarse-grained units thins in the down dip or southwest direction.

\subsubsection{Alluvial Plain Facies}

Alluvial plain facies are characterized by sedimentary deposits that are better sorted than the proximal alluvial fan facies, as evidenced in cross-sections (e.g., Cross-Section D-D', Figure 6, distance markers 27,000 to 35,000 for Pressure 400-Foot Aquifer "time"; and Cross-Section G-G', Figure 9, distance marker 35,000). The alluvial plain facies generally lack poorly sorted and chaotic mudflow, debris-flow, and landslide deposits, and instead are characterized by predominantly fine-grained, clay-rich deposits.

Within the study area, the transition from alluvial fan facies to alluvial plain facies is defined where the gravel and sand deposits transition into dominantly red, brown, and yellow clay facies, as illustrated in Figure 11, and observed in Cross-Section E-E' (Figure 7, distance markers 35,000 to 38,000 during Pressure 400-Foot Aquifer "time").

\subsubsection{Fluvial Facies}

\subsubsection{Fluvial Channel Facies}

Gravel and coarse sand are transported as bedload by high-velocity flows within fluvial channels. As the flow velocity decreases and/or the channel migrates laterally, coarse sand and rounded gravel are deposited as channel-lag deposits.

Within the study area, thick sequences of gravel and sand deposits are interpreted as stacked and coalescing fluvial channel sediments deposited by the active river channel that meandered back and forth across the Salinas Valley (Figure 11). This facies is common in the Pressure Subarea. 


\section{Kennedy/Jenks Consultants}

\subsubsection{Fluvial Overbank Facies}

The overbank areas of the fluvial floodplain are characterized by the vertical accretion of finegrained sediment (Figure 11). In the Pressure Subarea, brown or yellow clay or gravelly clay deposits that correlate laterally with coarser grained fluvial channel deposits are characteristic of overbank facies. In the Pressure/East Side transition region, oxidized brown clays of the fluvial floodplain or overbank facies can grade laterally into oxidized clays of the alluvial plain facies.

Note that as an active fluvial channel migrates laterally back and forth across a river valley, previously deposited fine-grained sediments of the floodplain can be eroded and redeposited, resulting in a complex mixture of both fine- and coarse-grained facies (Figure 11).

\subsection{East Side Subarea Ground Water}

\subsubsection{Aquifer Zones}

As reported in SGD (1993), previous studies of the East Side Subarea (e.g., MCFCWCD, 1960; SGD, 1990; Hall, 1992; and J.M. Montgomery Engineers, 1993) have presented some evidence for the designation of East Side shallow and East Side deep zones within the East Side Subarea, perhaps reflecting the changing climatic conditions that resulted in changes in sediment deposition. However, as noted by SGD (1993), and confirmed in this study, no evidence exists for a discrete confining layer that defines a deep and a shallow zone. SGD (1993) states that it is more likely that confinement increases with depth as a result of the interbedded nature of the stratigraphy.

\subsubsection{Ground Water Recharge}

Ground water recharge in the East Side Subarea occurs through percolation from small streams that flow from the Gabilan Range, and to a lesser degree, directly from precipitation during the wet years (DWR, 1946). Surface water is apparently slowly absorbed in the East Side Subarea, because pumping drawdown is large and fairly rapid (MCFCWCD, 1960).

Ground water from the East Side Subarea probably would migrate slowly into the Pressure aquifer in several places if the water table in the East Side Subarea were higher than the hydrostatic pressure head of the adjacent Pressure Subarea (MCFCWCD, 1960, p. 9). The East Side Subarea appears to have been one of the natural sources of recharge to the adjacent Pressure Subarea and ground water levels historically could have been higher than those in the Pressure Subarea. However, in recent years, pumping overdraft in the East Side Subarea has caused an apparent reversal of the ground water flow from the Pressure Subarea into the East Side Subarea.

\subsubsection{Well Yields}

Water well yields in the East Side Subarea are extremely variable, reflecting the variability of the stratigraphy. The aquifers generally are unconfined, but as reported in DWR (1946), some pockets of water-bearing gravels are under slight pressure due to partial local confinement. Heavy yielding wells with slight drawdowns are generally obtained in these pockets of water- 
bearing gravels, and yields in excess of 200 gallons per minute (gpm) per foot of drawdown are quite common. However, DWR (1946) also reports that there are some wells with low yield, which apparently were drilled in an alluvial plain ("...wells of low yield... are largely confined to strips of overlap in the outwash of deltas of various tributaries on the east side of the valley." [DWR, 1946, p. 15]).

\subsubsection{Water Quality}

The 500 milligrams per liter chloride contour line is used as a guide to identify and track the progression of the seawater intrusion front. As shown on Figure 10, the seawater intrusion fronts in both the Pressure 180-Foot and Pressure 400-Foot Aquifers have not reached the East Side Subarea. 
Kennedy/Jenks Consultants

\section{Section 5: Transition Between Pressure and East Side Subareas}

This section defines the boundary between the Pressure and East Side Subareas, and discusses the types of stratigraphic relationships between the fluvial and alluvial fan facies observed in the transition zone. A generalized depositional model for the northern Salinas Valley is presented in this section. In addition, this section discusses how the depositional origin of the stratigraphic facies controls the hydraulic connectivity across the Pressure/East Side boundary.

\subsection{Boundary Between the Pressure and East Side Subareas}

\subsubsection{Boundary as Defined by Earlier Studies}

The boundaries between subareas of the Salinas Valley were originally defined by DWR (1946, p. 12) in Bulletin 52 based on the source of ground water recharge for each subarea. However, Bulletin 52 also stated that the boundary between the Pressure Subarea and the East Side Subarea was defined by the southerly limit of influence of the alluvial fan systems originating in the eastern and northern watersheds. In Bulletin 52 (DWR, 1946), this limit was based on the distribution of blue clay in the drillers' logs (with the blue clay considered to be indicative of estuarine depositional environments).

The boundaries between the subareas were slightly modified later by MCFCWCD (1960), and the boundary of the East Side Subarea was modified in the area near Gonzales (approximately 16 miles south of Salinas). The currently adopted boundary between the East Side and Pressure Subareas as defined in the published literature (SGD, 1993) is shown in Figure 1.

\subsubsection{Boundary as Defined in the Study}

Rather than defining the boundary between the Pressure Subarea and the East Side Subarea by the distribution of blue clays as was done by DWR (1946), the boundary between the Pressure and East Side Subareas is defined in this study by the transition from predominantly fluvial facies (as defined in Section 4.3.2) to predominantly alluvial fan facies (as defined in Section 4.3.1). Specifically, the zone between the northeast extent of the fluvial channel facies and the southwest extent of the alluvial fan facies (i.e., the interfingering fluvial floodplain and alluvial plain area) is designated as the transition zone between the Pressure and East Side Subareas (Figure 11).

With this methodology put forth in defining the transition zone, we have proposed the location and extent of the Pressure/East Side transition zone during deposition of both the Pressure 180-Foot Aquifer (red hatched area) and the Pressure 400-Foot Aquifer (green hatched area), as shown in Figure 12. 


\section{Kennedy/Jenks Consultants}

\subsection{Transition Zone Between Pressure and East Side Subareas - Stratigraphic Characteristics}

\subsubsection{Stratigraphic Facies Scenarios}

The stratigraphic characteristics of the transition zone are variable due to the different stratigraphic relationships between fluvial and alluvial facies, as observed in the cross-sections. Three different stratigraphic facies scenarios were observed in the transition zone within the study area:

1. Permeable facies (i.e., gravel and sand deposits) of the Pressure Subarea are in contact with permeable facies of the East Side Subarea (Figure 13, Scenarios 1A and 1B);

2. Impermeable or low permeability (i.e., clay) facies of the Pressure Subarea are in contact with impermeable or low permeability facies of the East Side Subarea (Figure 14, Scenario 2); and

3. Impermeable blue clay facies of the Pressure Subarea are in contact with permeable (i.e., gravel and sand) facies of the East Side Subarea (Figure 15, Scenarios 3A and $3 \mathrm{~B})$.

Facies Scenario $1 A$ occurs where the meandering of the Salinas River within the northern Salinas Valley has caused the river to incise the alluvial fan facies (Figure 13). This facies scenario is observed in the Pressure 180-Foot Aquifer on Cross-Section D-D' (Figure 6) at distance markers 27,000 to 31,000 . Alternatively, the facies geometry on Cross-Section D-D' could be interpreted to represent facies scenario $1 \mathrm{~B}$.

Facies Scenario 1B occurs where the alluvial fan system has prograded into the fluvial system (Figure 13). Scenario 1B would result in gravel and sand deposits of the fluvial system being in direct contact with the gravel and sand deposits of the alluvial fan system, which could allow the flow of ground water across the Pressure/East Side boundary. This facies scenario is observed to occur on Cross-Section E-E' (Figure 7, distance markers 33,000 to 37,000; note that decomposed granite from the alluvial fan facies progrades out over fluvial channel facies). As noted above, facies scenario 1B could also be interpreted on Cross-Section D-D' (Figure 6) at distance markers 27,000 to 31,000 .

Facies Scenario 2 occurs where the main active channel of the ancient Salinas River is separated from the coarse-grained alluvial fan facies by both fluvial overbank/floodplain deposits and by alluvial plain (i.e., distal alluvial fan) deposits (Figure 14). In this situation, the clay-rich overbank facies are in contact with the clay-rich alluvial plain facies, creating a barrier to the lateral flow of ground water from the Pressure Subarea to the East Side Subarea. This facies relationship is observed to occur within both the Pressure 180-Foot Aquifer and Pressure 400-Foot Aquifer on Cross-Sections C-C' (Figure 5, distance markers 25,000 to 30,000), F-F' (Figure 8, distance markers 33,000 to 36,000), and G-G' (Figure 9, distance markers 32,000 to 35,000). Facies scenario 2 occurs only within the Pressure 400-Foot Aquifer on Cross-Sections D-D' (Figure 6, distance markers 27,000 to 35,000) and E-E' (Figure 7, distance markers 34,000 to 36,000$)$. However, it should be noted that interbedded sand/gravel/clay or sandy clay of the Pressure Subarea most likely is in lateral contact with gravelly clay and sandy clay of the East 


\section{Kennedy/Jenks Consultants}

Side Subarea on Cross-Section E-E' within the Pressure 400-Foot Aquifer (Figure 7, distance markers 34,000 to 37,000), and on Cross-Section C-C' in both the Pressure 180-Foot and Pressure 400-Foot Aquifers (Figure 5, distance markers 25,000 to 30,000). This facies relationship may create only a restriction, rather than a barrier, to ground water flow across the Pressure/East Side boundary.

Facies Scenario $3 A$ is observed due to a relative sea level rise, which resulted in the "drowning" of the northern Salinas Valley (Figure 15). The subsequent development of estuarine or shallow-marine environments in the northern Salinas Valley resulted in the deposition of organic-rich blue clay under anoxic or suboxic submarine conditions.

Facies Scenario $3 B$ represents one possible facies relationship resulting from a relative rise in sea level. In facies scenario 3B, blue clay onlaps both alluvial plain and alluvial fan facies (Figure 15). Blue clay facies that onlap alluvial facies deposited during the Pressure 180-Foot Aquifer "time" are observed on Cross-Section D-D' (Figure 6, distance markers 29,000 to 32,000 ) and Cross-Section F-F' (Figure 8, distance markers 39,000 to 44,000).

Another possible facies relationship in the transition zone (not illustrated in Figure 15) is that the alluvial fans prograded into an estuarine environment, resulting in alluvial gravel and sand interfingering with estuarine mud (i.e., blue clay). This facies scenario would reduce the lateral flow of ground water across the Pressure/East Side boundary, and where the blue clay facies caps a permeable facies, the vertical flow of water would also be impeded.

Blue clay facies do not appear to have been deposited during the Pressure 400-Foot Aquifer "time" in the East Side Subarea; alternatively, blue clay facies may have been deposited, but were subsequently eroded.

\subsubsection{Characteristics of the Pressure 180-Foot and Pressure 400-Foot Aquifers Near the Transition Zone}

The Pressure 180-Foot Aquifer and the Pressure 400-Foot Aquifer are not in vertical communication with one another in the Pressure Subarea adjacent to the transition zone. However, as described in Section 3.1.4.1, there are locations within the Pressure Subarea where discontinuities in the Pressure 180/400-Foot Aquitard, as depicted in the cross-sections, suggest that the two aquifers could be in hydraulic communication (Figure 10).

The fluvial channel deposits of the Pressure 180-Foot Aquifer appear to be more segmented and lenticular than the Pressure 400-Foot Aquifer. This characteristic is most evident on CrossSections C-C' (Figure 5, distance markers 7,000 to 26,000) and E-E' (Figure 7, distance markers 25,000 to 34,000 ). The isolated fluvial channel deposits of the Pressure 180-Foot Aquifer (versus the relatively thick and widespread sand bodies of the Pressure 400-Foot Aquifer) suggest that the Salinas River did not meander back and forth across the valley floor during deposition of the Pressure 180-Foot Aquifer as frequently as it did during deposition of the Pressure 400-Foot Aquifer.

The fluvial channel deposits of the Pressure 180-Foot and Pressure 400-Foot Aquifers are separated from the alluvial fan facies by a sandy clay and gravelly clay facies on Cross-Sections 


\section{Kennedy/Jenks Consultants}

C-C' (Figure 5, distance markers 25,000 to 30,000) and E-E' (Figure 7, distance markers 34,000 to 37,000$)$. These semipermeable facies may restrict but not totally stop the flow of ground water across the Pressure/East Side boundary.

\subsection{Depositional Model}

\subsubsection{Sediment Sources in the Northern Salinas Valley}

The northern Salinas Valley during the Quaternary period was dominated by two sediment sources: (1) alluvial fans building out along the borders of the Salinas Valley, and (2) the Salinas River system. Alluvial fans developed along the northeastern boundary of the Salinas Valley as a result of both uplift of the Gabilan Range and the discharge of streams into the valley. In the East Side Subarea, during Pleistocene to Holocene time when the Pressure 180-Foot and Pressure 400-Foot Aquifers were being deposited in the Pressure Subarea ${ }^{1}$, alluvial fans building out from the Gabilan Range graded into the ancient Salinas River.

The ancient Salinas River flowed northwestward parallel to the Gabilan Range. Predominantly gravel and sand were deposited along the river channel, and finer sediments such as silt and clay were deposited as overbank deposits on the floodplain during flooding events. The ancient Salinas River frequently meandered back and forth across the valley floor, cutting through old sedimentary beds and depositing new fluvial sediments. This meandering activity appears to have been more common during deposition of the Pressure 400-Foot Aquifer than during the Pressure 180-Foot Aquifer, as suggested by the relatively continuous sand bodies of the Pressure 400-Foot Aquifer. This depositional process was punctuated by torrential floods that carved out new channels and deposited poorly sorted mixtures of boulders, gravel, sand, silt, and clay. The resulting fluvial sedimentary successions, comprising the Pressure 400-Foot and Pressure 180-Foot Aquifers, are complex sequences of gravel and sand containing discontinuous beds of silt and clay.

\subsubsection{Glacio-Eustatic Control of Depositional Facies}

As noted by Tinsley (1975), the Salinas River eroded sediments and alluviated its channel in response to repeated glacio-eustatic sea level changes during the Quaternary period. Eustatic lowering of sea level during the onset of late Wisconsin (Pleistocene) glaciation caused the Salinas River and its tributaries to incise the sediments that filled the Salinas Valley. As the glaciers subsequently diminished and melted, the rate of sea level rise exceeded the rate at which sediment was deposited in the Salinas Valley. This relative rise in sea level caused a substantial portion of the northern Salinas Valley to be "drowned". It was during these marine transgressions that blue clay, characteristic of the northern Salinas Valley aquitards, was deposited in estuarine or shallow-marine environments.

\footnotetext{
${ }^{1}$ The age of the Pressure 180-Foot Aquifer has been estimated as Pleistocene to Holocene (Greene, 1970; Manning, 1963), and the age of the Pressure 400-Foot Aquifer has been estimated as PlioPleistocene (Greene, 1970) or mid-Pleistocene (Manning, 1963).
} 


\section{Kennedy/Jenks Consultants}

During the Holocene, shallow submarine portions of the Salinas Valley possibly resembled the modern-day Elkhorn Slough or Tomales Bay. Confirmed evidence of estuarine conditions has been found as far inland as Salinas (Tinsley, 1975), and stratigraphic correlations completed as part of this study confirm that blue clay facies onlap the alluvial fan facies near northeastern Salinas. Figure 16 shows the northeasternmost extent of the blue clay facies above the Pressure 180-Foot Aquifer within the study area. As suggested by Tinsley (1975), fresh water marsh environments and/or possibly estuarine environments may have existed between Salinas and Gonzales (approximately 16 miles south of Salinas, i.e., outside of the study area), accounting for the less continuous aquiclude strata that are located there.

\subsubsection{Interaction Between Fluvial and Alluvial Fan Depositional Systems}

The interaction between the alluvial fans and the Salinas fluvial system through time has created an interesting and complex stratigraphic relationship along the boundary between the Pressure Subarea and the East Side Subarea. In Tinsley's (1975) study of alluvial fan morphology within the northern Salinas Valley, he noted that in numerous locations, the toes of modern-day alluvial fans were eroded and sheared off by the lateral meandering of the Salinas River. Erosion of the toe of an alluvial fan would trigger the distributary drainages to react to a locally lowered base level by incising the alluvial fan. This event, in turn, would cause the distributary channel to deposit new fans that prograde across the fluvial floodplain. Aggradation by the Salinas River would result in the burial of distal portions of alluvial fans by floodplain deposits. These processes are occurring today, and most likely also occurred in the past. Thus, the Quaternary stratigraphic succession along the Pressure/East Side boundary records a complex pattern of erosion and deposition and is characterized by intertonguing fluvial facies deposited by the Salinas River and alluvial fan facies deposited by distributary streams.

\subsubsection{Sediment Provenance and the Southward Progression of Alluvial Fans}

The provenances of the clasts within the fluvial and alluvial fan gravel deposits have been used to develop a conceptual model for deposition of the Salinas Valley fill (Tinsley, 1975). Alluvial fan deposits on the east side of the Salinas Valley contain clasts derived exclusively from Salinian basement terranes in the Gabilan Range (similarly, alluvial fan deposits of the west side of the Salinas Valley contain clasts derived exclusively from Salinian basement terranes in the Sierra de Salinas). Decomposed granite, which provides evidence of this granitic provenance, is characteristic of the interpreted East Side alluvial fan deposits. Decomposed granite is noted in logs included in Cross-Sections E-E' (Figure 7, well 14S/03E-09P03, distance marker 33,500) and F-F' (Figure 8, well 14S03E02L50, distance marker 46,500) and has also been noted in several drillers' logs. In comparison, the provenance of the Salinas River deposits is predominantly Tertiary sedimentary rocks. The fluvial deposits commonly contain clasts of siliceous shale and porcelaneous chert and "chalk rock" from the Monterey Shale. In contrast, the alluvial fan deposits are notably void of clasts derived from Tertiary sedimentary rocks.

The lithology of clasts records the progression of the alluvial fans to the south and the displacement of the Salinas River to the south through time. According to SGD (1993), lithologic data from wells in the Pressure Subarea indicate that both the Pressure 400-Foot Aquifer and 


\section{Kennedy/Jenks Consultants}

the Pressure 180-Foot Aquifer contain significant amounts of porcelaneous chert clasts derived from the Monterey Shale. However, wells in the East Side Subarea (as defined by SGD [1993]) contained porcelaneous chert clasts derived from the Monterey Shale in the Pressure 400-Foot Aquifer, but Monterey Shale clasts were absent from the Pressure 180-Foot Aquifer. This records the progression of the alluvial fans to the south and the displacement of the Salinas River to the south through time.

The stratigraphic correlations completed as a part of this study also record the southward progression of the alluvial fan facies through time. The alluvial fan facies (as defined in Section 4.3.1) were correlated on the stratigraphic cross-sections, and the distribution of the alluvial fan facies was mapped for both Pressure 180-Foot and Pressure 400-Foot Aquifer "time" (Figure 16). The red-hatched pattern shows the extent of the alluvial fan facies during deposition of the Pressure 400-Foot Aquifer, and the green-hatched pattern represents the extent of the alluvial fan facies during deposition of the Pressure 180-Foot Aquifer (Figure 16). As inferred from the stratigraphic interpretations on Cross-Sections C-C' through G-G', the alluvial fans deposited during Pressure 180-Foot Aquifer "time" extended (progressed) farther southwest than the alluvial fans deposited during Pressure 400-Foot Aquifer "time".

\subsubsection{Distribution of Depositional Facies}

The fluvial, alluvial plain, and alluvial fan facies were interpreted and correlated on the stratigraphic cross-sections as part of this study. The distribution of these facies for both Pressure 180-Foot Aquifer "time" and Pressure 400-Foot Aquifer "time" are shown on Figures 17 and 18, respectively.

During deposition of the Pressure 180-Foot Aquifer, the alluvial fan facies appears to have prograded southwestward relative to where the alluvial fan facies were located during Pressure 400-Foot Aquifer "time" (Figure 17). The alluvial plain facies is relatively narrower than during deposition of the Pressure 400-Foot Aquifer, as shown on the facies distribution map (Figure 17). The fluvial channel may have incised the toes of the alluvial fan system, or the alluvial fan system may have prograded into the river system during the Pressure 180-Foot Aquifer "time", as inferred from Cross-Sections D-D' (Figure 6, distance markers 27,000 to 31,000 ) and E-E' (Figure 7, distance markers 33,000 to 37,000). The fluvial system that formed the Pressure 180-Foot Aquifer is characterized by more persistent overbank areas than during deposition of the Pressure 400-Foot Aquifer. The overbank areas (characterized by clay facies in cross-sections) are depicted as elongate bands of fluvial overbank deposits oriented parallel to the ancestral flow direction (NW) of the fluvial system (Figure 17). In addition, the sand bodies within the Pressure 180-Foot Aquifer near the transition zone are more segmented than in the Pressure 400-Foot Aquifer, particularly on Cross-Sections C-C' (Figure 5, distance markers 25,000 to 26,000) and E-E' (Figure 7, distance markers 25,000 to 34,000).

During deposition of the Pressure 400-Foot Aquifer, the alluvial fan facies were separated from the active fluvial channel facies by a relatively wide area comprised of alluvial plain and fluvial overbank facies (Figure 18). The fluvial system was characterized by fluvial channels that appear to have actively meandered back and forth across the river valley, depositing predominantly coarse-grained sediments. Overbank areas that persisted throughout the deposition of the entire Pressure 400-Foot Aquifer are present in limited areas of the eastern part of the study area (Figure 18). 


\section{Kennedy/Jenks Consultants}

\subsection{Hydraulic Connectivity of East Side Subarea and Transition Zone}

This section describes the control that the depositional environments and depositional facies have on the hydraulic connectivity of the Pressure and East Side Subareas. The hydraulic properties of the transition zone are controlled by the interface between the fluvial and alluvial fan facies. This section also discusses the horizontal and vertical connectivity of the aquifer zones and possible ground water flow pathways, as controlled by sedimentary facies.

\subsubsection{Depositional Facies Control of Hydraulic Connectivity}

The transition zone marks the region where the relatively well defined and correlatable stratigraphy of the Pressure Subarea changes to the less predictable and more discontinuous stratigraphy of the East Side Subarea. Depositional environments control the sedimentary facies, which, in turn, control the hydraulic properties of the two subareas.

The Pressure Subarea, in general, is dominated by relatively thick and continuous, permeable sand and gravel deposits of fluvial origin. In contrast, the East Side Subarea is dominated by discontinuous and lenticular sand and gravel beds and abundant clay deposited by alluvial fans. The sedimentary facies characteristics of the East Side Subarea would suggest that the wells in this area would be lower yielding and that the hydraulic connectivity would be reduced relative to the Pressure Subarea. This would also suggest that seawater intrusion would occur at a substantially slower rate in the East Side Subarea than has been observed in the Pressure Subarea. The depositional environments, sedimentary characteristics, and hydraulic properties of the Pressure and East Side Subareas are summarized in Table 2.

As stated by SGD (1993), sediments comprising the water-bearing zones of the East Side Subarea likely have hydraulic conductivities that are at least an order of magnitude lower than the sediments comprising the Pressure 180-Foot Aquifer zone of the Pressure Subarea. As estimated by SGD (1993, p. 34), even under a gradient of twice that which drove the seawater intrusion front to its current location, ground water velocities would be approximately 5 times slower within the East Side Subarea than in the Pressure Subarea as a result of the reduced hydraulic connectivity.

The quality of aquicludes and aquifers has been defined by MCFCWCD (1960) based on the sedimentary facies comprising these aquicludes and aquifers. These descriptions are useful when predicting hydraulic conductivities based on information presented in the stratigraphic cross-sections and in drillers' logs. The categories of aquicludes and aquifers as defined by MCFCWCD (1960) are as follows:

- Impermeable - Good Aquicludes: Blue clay, gray clay, white clay, adobe

- Nearly Impermeable - Poor Aquicludes: Yellow, red, brown clay

- Semipermeable - Poor Aquicludes: Blue sandy clay, blue gravely clay, silty clays 


\section{Kennedy/Jenks Consultants}

- Semipermeable - Poor Aquifers: Yellow, red, or brown sandy or gravelly clays; sediment; "seepage"2, silt, silty sand

- Permeable - Good Aquifers: Sand, sand \& gravel, gravel, cobbles

\subsubsection{Hydraulic Properties of Transition Zone}

The hydraulic properties vary along the length of the boundary between the Pressure and East Side Subareas based on the geometries of the intertonguing facies between the Pressure and East Side Subareas. The three stratigraphic facies scenarios observed in the transition zone and the resulting hydraulic properties are:

1. Permeable fluvial facies of the Pressure Subarea are in contact with permeable alluvial fan facies of the East Side Subarea: This situation creates hydraulic connectivity across the Pressure/East Side boundary.

2. Impermeable or low permeability fluvial overbank facies of the Pressure Subarea are in contact with impermeable or low permeability alluvial plain facies of the East Side Subarea: This situation restricts the flow of ground water across the boundary.

3. Impermeable blue clay facies of the Pressure Subarea are in contact with permeable alluvial fan facies of the East Side Subarea: This impedes or stops the flow of ground water across the boundary and/or in a vertical direction (although it should be noted that this scenario only affects the uppermost part of the Pressure 180-Foot Aquifer).

\subsubsection{Possible Areas of Horizontal and Vertical Hydraulic Connectivity}

\subsubsection{Horizontal Flow Across Pressure/East Side Boundary}

Evidence for hydraulic connectivity across the Pressure/East Side boundary was noted by DWR (1946, p. 78): "Contours of ground water elevations indicate the main tongue of gravel deposits in several of the East Side Area deltas may be interconnected with the water-bearing formations in the Pressure Area."

The work completed in this study suggests that the potential exists for hydraulic connectivity through permeable sediments across the Pressure/East Side boundary within the Pressure 180-Foot Aquifer in the vicinity of Cross-Sections D-D' (Figure 6, distance markers 26,000 to 32,000 ) and E-E' (Figure 7, distance markers 33,000 to 37,000 ). The plan view of these areas is illustrated in Figure 17.

There is also the potential for hydraulic flow across the boundary through semipermeable sediments within the Pressure 180-Foot and Pressure 400-Foot Aquifers in the vicinity of CrossSection C-C' (Figure 5, distance markers 25,000 to 30,000), and within the Pressure 400-Foot

2 "Seepage" is defined by well drillers as a sandy and gravelly clay material through which water seeps slowly (MCFCWCD, 1960). 


\section{Kennedy/Jenks Consultants}

Aquifer of Cross-Section E-E' (Figure 7, distance markers 34,000 to 37,000 ). The plan view of these areas are illustrated in Figures 17 and 18

\subsubsection{Vertical Flow within the East Side Subarea}

The East Side Subarea does not have a discrete confining layer that separates the East Side shallow zone from the East Side deeper zone. Even so, the East Side Subarea, in general, does not appear to be characterized by high vertical hydraulic connectivity; the gravel and sand beds are lenticular and thin rapidly in the down dip direction. In addition, sandy clay, gravelly clay, and interbedded sand and clay are common sedimentary facies within the East Side Subarea, which MCFCWCD (1960) defines as semipermeable deposits or "poor aquifers".

\subsubsection{Horizontal Flow within the Pressure Subarea}

The fluvial facies were mapped for both the Pressure 180-Foot Aquifer (Figure 17) and the Pressure 400-Foot Aquifer (Figure 18). These sand-rich facies are elongate in the northwestsoutheast direction, parallel to the long axis of the Pressure Subarea. The sand-rich fairways, shown in yellow on Figures 17 and 18, represent areas of relatively high lateral hydraulic connectivity and therefore represent the potential preferential pathways where seawater intrusion might occur.

As shown in Figure 17 and discussed in Section 5.2.2, the Pressure 180-Foot Aquifer is more segmented than the Pressure 400-Foot Aquifer, and is characterized by fluvial areas that persisted during the deposition of the Pressure 180-Foot Aquifer. Because these clay-rich overbank deposits are less permeable than the sand-rich fluvial channel deposits, these elongate overbank areas would be expected to direct or focus the flow of ground water (and therefore the migration of seawater) within the Pressure 180-Foot Aquifer. Accordingly, Figure 17 shows that the 2001 seawater intrusion front in the Pressure 180-Foot Aquifer appears to conform to the boundary of the clay-rich facies of the fluvial overbank materials. 
Kennedy/Jenks Consultants

\section{Section 6: Seawater Intrusion}

The goal of this study in terms of assessing the conditions of seawater intrusion is to develop a time line of estimated impact by a seawater front to identified benchmarks such as the City of Salinas and the East Side pumping wells. The 500 milligrams per liter ( $\mathrm{mg} / \mathrm{L}$ ) chloride level is used as an indicator of degradation of ground water and it is promulgated as a Secondary Drinking Water Standard upper limit for chloride. The Agency also uses this concentration to demarcate the landward edge of the seawater intrusion front where denser seawater has intruded ground water.

The Agency samples dedicated monitoring and agricultural production wells each summer for chloride and other inorganic constituents in documenting the advancement of seawater intrusion. The seawater intrusion fronts shown in Figures 19 and 20, as represented by the $500 \mathrm{mg} / \mathrm{L}$ chloride contours for the Pressure 180-Foot and Pressure 400-Foot Aquifers, were provided by the Agency and are based on results from the August 2001 sampling event, i.e., the most recent data available during this study.

\subsection{Mechanisms of Seawater Intrusion}

The core condition for seawater intrusion in this area is that the aquifers are in direct hydraulic contact with the Monterey Bay. The secondary condition for seawater mixing in the Pressure $180-$ Foot and Pressure 400-Foot fresh water aquifers is that ground water levels in both aquifers are below sea level and the normal landward to seaward gradient had been reversed as seaward to landward in the Pressure 180-Foot Aquifer zone since the 1930s.

\subsubsection{Three Seawater Intrusion Mechanisms in the Northern Salinas Valley}

The pattern of encroaching seawater in ground water zones in the northern Salinas Valley as represented by $500 \mathrm{mg} / \mathrm{L}$ contours is the result of three primary seawater intrusion mechanisms that have been studied by numerous investigators in this area:

1. Commonly referred to as regional seawater intrusion, seawater infiltrates the Pressure 180-Foot and Pressure 400-Foot Aquifers through the submarine outcrops of aquifers offshore of Monterey Bay. As a result of ground water pumping in both aquifers, the water table in the Pressure 180-Foot Aquifer and the piezometric surface of the Pressure 400-Foot Aquifer have dropped below sea level (Section 3.2) thereby developing a landward hydraulic gradient inducing seawater to invade the fresh water aquifers (e.g. DWR [1973] and Todd [1989]).

2. In the case of interaquifer seawater intrusion, the aquitard between the Pressure 180 -Foot Aquifer and Pressure 400-Foot Aquifer is thin to discontinuous in localized areas and water in the aquifers can mix. This can allow seawater-blended ground water in the Pressure 180-Aquifer to migrate downward into the Pressure 400-Foot Aquifer (e.g. DWR [1973]). This downward migration is due to ground water pumping in both aquifers, which produced a downward gradient between the two aquifers. The head 


\section{Kennedy/Jenks Consultants}

difference was reported in 1989 to be about 30 to 40 feet (Todd, 1989; details presented in Sections 3.2 and 6.6 of this report).

3. Poorly constructed wells or wells with long screen sections with improper seals can also result in seawater intrusion. Some wells are screened in both the Pressure 180-Foot Aquifer and Pressure 400-Foot Aquifer (see Thorup [1976]), drawing ground water from both aquifers and thereby providing a conduit between aquifers (e.g. Todd [1988]).

This study focuses on the above mechanisms 1 and 2, which are related to hydrostratigraphic attributes in the Pressure 180-Foot and Pressure 400-Foot Aquifers that may allow regional and interaquifer seawater intrusion. Communication between aquifers due to poor well construction is not discussed in this report.

\subsection{Methods of Assessing the Rate of Seawater Intrusion}

In this study we assess the expansion of intruded areas based on documented delineations of the chloride concentrations through time as contours of the front have been published by the Monterey County Flood Control \& Water Conservation District (MCFCWCD) now the Monterey County Water Resources Agency since 1944. We place emphasis on the cumulative rates of intrusion as estimated separately for the Pressure 180-Foot and Pressure 400-Foot Aquifers in this study, in Todd (1989), and others (including the Agency). The rationale behind the use of cumulative rates is that the mapped front can occasionally jump ahead in a particular direction, as discussed in SGD (1993). Occasional jumps in intruded areas are as likely due to addition of monitoring wells or data points landward of the intrusion front. Although the expansion of intrusion area(s) of seawater is based on data, the suggested increased rate of expansion may not be realistic. We demonstrate in this study (Table 3) that there is no consistent trend in the data to support the use of "periodically higher" seawater intrusion rates to estimate long-term movements of seawater in the Pressure Subarea aquifers.

Table 3 is a database of seawater intrusion areas as published by the Agency in the form of contours for periods of time (e.g., 1944 to 1965). Intrusion distances are measured distance in the GIS along a particular path line (6 paths in the 180-Foot and 5 paths in the Pressure 400Foot Aquifer). Three different seawater intrusion rates (feet per year, $\mathrm{ft} / \mathrm{yr}$ ) are calculated by dividing these distances (feet) with the periods (years):

1. Periodic rate - based on the number of years and within a given period;

2. Intermediate rate - an average of all rates in what is considered as "pre-1993" for the Pressure 180-Foot Aquifer and "pre-1997 for the Pressure 400-Foot Aquifer. Intrusion rates for years after these periods and considered as "recent intrusion periods" are also listed.

3. Cumulative rate - an average of all intrusion rates for a particular path.

We believe that the rate of expansion of intruded seawater can accelerate in a certain direction due to increased pumping or short-term drops in ground water levels landward of the front during prolonged droughts. Likewise, a short-term reduction of intruding seawater can occur in wet years as ground water levels are correspondingly higher, like in 1995 (Agency, 1997). However, there is no historical information that suggests that the cumulative rate of seawater 


\section{Kennedy/Jenks Consultants}

intrusion in the northward and southeastward directions have increased. In fact, the "averaged" cumulative rate of seawater intrusion has been approximately $500 \mathrm{ft} / \mathrm{yr}$ for the Pressure 180Foot Aquifer and about $450 \mathrm{ft} / \mathrm{yr}$ for the Pressure 400-Foot Aquifer.

We take the following steps to achieve our goal of developing a time line to characterize the expansion of seawater intrusion:

1. Use the Ghyben-Herzberg Principle as a generalized model for regionally intruding seawater in the coastal areas;

2. Use historic chloride levels to estimate the rate at which seawater has moved in a landward direction; and

3. Qualitatively estimate the combined effects of regional intrusion in both aquifers with interaquifer flow as postulated in localized areas within the Pressure Subarea (Section 3.1.4).

\subsubsection{The Ghyben-Herzberg Principle}

The bodies of fresh water in the Pressure 180-Foot Aquifer and the confined ground water in the Pressure 400-Foot Aquifer conform to Archimedes' law of buoyancy. This law implies that fresh water in the Pressure 180-Foot Aquifer will be displaced by its own weight of the medium in which it floats. The ground water within the Pressure 400-Foot Aquifer, which is confined by the overlying aquitard, will be displaced landward to areas of lower piezometric heads such as those areas within the ground water pumping trough beneath with the City of Salinas. This displacement mechanism between denser seawater and more buoyant fresh water is commonly referred to as the Ghyben-Herzberg Principle (Freeze and Cherry, 1979).

According to the Ghyben-Herzberg principle, coastal aquifers with ground water levels below sea level will be intruded by denser seawater. This means that ground water in most of the East Side and Pressure subareas west of the City of Salinas, where the water table is down to 20 to 80 feet below sea level (Agency 1997) could have elevated levels of chloride exceeding $500 \mathrm{mg} / \mathrm{L}$ - as a result of seawater blending with fresh water. However, this situation is clearly not readily apparent as mapped intrusion fronts for both aquifers are located seaward of the City of Salinas (Figure 10). This is because ground water is flowing towards the coast and there is sufficient ground water storage in both aquifers to maintain a regional seaward gradient. This is particularly so for ground water upgradient or east of the City of Salinas.

\subsubsection{Mapping of Chloride Front}

A more representative characterization of seawater intrusion is the use of empirical rate estimations to evaluate landward increases in chloride levels with time. Specifically, we calculate rates of advances of the $500 \mathrm{mg} / \mathrm{L}$ chloride contours by dividing the maximum linear distance (feet) that the $500 \mathrm{mg} / \mathrm{L}$ front has moved by the corresponding time period of advancement (years). 
Kennedy/Jenks Consultants

\subsection{Regional Seawater Intrusion}

The submarine outcrop of the Pressure 180-Foot Aquifer and Pressure 400-Foot Aquifer offshore of the Monterey coast was presented in Greene (1970) and analyzed in Todd (1989). Submarine outcrops are the main portals for seawater entry into the Pressure 180-Foot Aquifer and Pressure 400-Foot Aquifer. This mechanism is also referred to as regional seawater intrusion.

The bathymetric findings presented in Greene (1970) indicate that deltaic sediments extend offshore from the mouth of the Salinas River; these sediments are several hundred feet thick near the shore and thin to the west. Greene (1970) correlates the offshore delta sediments with the onshore Valley Fill deposits (in which he includes the Pressure 180-Foot Aquifer). Greene (1970) indicates that the Aromas Sand and Paso Robles Formation are seismically indistinguishable from each other, and are exposed on the floor of Monterey Bay west of the Salinas River delta deposits and also exposed for a small distance along the south side of Monterey Canyon. Both Greene (1970) and Todd (1989) correlate the submarine deltaic deposits with the Pressure 180-Foot Aquifer. Greene (1970) does not portray the outcrop of the Pressure 400-Foot Aquifer on the floor of Monterey Bay, but Todd (1989) portrays the entire submarine outcrop of the combined Aromas Sand and Paso Robles Formation as correlating with and communicating with the Pressure 400-Foot Aquifer.

The area of the submarine exposure of the Pressure 180-Foot Aquifer as shown in Todd (1989) is approximately 7.0 square miles, and the submarine exposure of the Pressure 400 -Foot Aquifer is approximately 9.1 square miles. The extent of the Pressure 180-Foot Aquifer as shown in Greene (1970) is approximately 6.7 square miles, and the exposure of the combined Aromas Sand and Paso Robles Formation is approximately 10.3 square miles.

Regional seawater intrusion (Mechanism 1) is discussed below in Sections 6.4 and 6.5 for the Pressure 180-Foot and Pressure 400-Foot aquifers, respectively. The interaquifer seawater intrusion (Mechanism 2) for the Pressure 180/400 Aquitard is discussed in Section 6.6.

\subsection{Regional Seawater Intrusion in the Pressure 180-Foot Aquifer}

Seawater intrusion has been known to occur in the Pressure 180-Foot Aquifer since the 1930s and has been documented beginning in 1946 (DWR, 1946). Historical tracking of the seawater intrusion fronts as depicted in Figure 19 indicates that seawater has been migrating from along the coast line between Castroville in the north and Fort Ord in the south down the center of the Pressure Subarea. Todd (1989) estimated that the seawater intrusion front advanced landward at about $425 \mathrm{ft} / \mathrm{yr}$ in the west to east and east to southeast directions. The rate is about $514 \mathrm{ft} / \mathrm{yr}$ in the northwest to southeast direction.

An abundance of chloride data in ground water samples taken from 1944 to the present has allowed this study to methodically define compartments or "corridors" of seawater movement and then calculate the variable rates of seawater movements within each corridor. Path-lines in Figure 19 depict seawater travel paths in six corridors and rates of seawater movement are calculated along each path. These corridors are not meant to distinguish hydrostratigraphic 


\section{Kennedy/Jenks Consultants}

conditions but merely to serve as a spatial statistical means to: 1) calculate linear rates of travel, 2) compare and explain differences in rates, and 3) derive a future-time-table that predicts when "separate" seawater fronts to reach certain benchmark areas along their travel paths.

Table 3 presents detailed calculations of rates of seawater intrusions as delineated by successive $500 \mathrm{mg} / \mathrm{L}$ contours in Figure 19. The Pressure 180-Foot Aquifer calculations are on the left side of Table 3 and intrusion rates (ft/yr) are summarized below.

\begin{tabular}{|c|c|c|c|c|c|c|}
\hline Path \# & 1 & 2 & 3 & 4 & 5 & 6 \\
\hline $1944-1993$ & 253 & 374 & 566 & 458 & 477 & 612 \\
\hline $1993-2001$ & 0 & 0 & 188 & 958 & 733 & 0 \\
\hline Cumulative & 202 & 299 & 440 & 673 & 587 & 205 \\
\hline
\end{tabular}

\section{Discussion}

Paths 4 and 5 in Figure 19 are considered the axes of seawater intrusion in this aquifer zone. Path 4 has the highest rate of movement $(673 \mathrm{ft} / \mathrm{yr})$ and it is the most direct path of seawater encroachment on the City of Salinas. Path 5 showing the second highest rate of seawater movement (587 ft/yr) has a southwesterly direction towards Blanco Road and the Salinas River. Compared to other paths of seawater intrusion, Paths 4 and 5 have an apparent jump in seawater advancement (2,000 and 1,000 ft/yr, respectively) in the three years from 1997 to 1999 (Table 3). However this apparent acceleration was not sustained and rates returned back to the typical 300 to $400 \mathrm{ft} / \mathrm{yr}$ after 1999 (Table 3).

Paths 1, 2, and 3 represent seawater advances towards Castroville and the East Side Subarea. These paths possess slower rates of intrusion (202 to $440 \mathrm{ft} / \mathrm{yr}$ ) and are clearly defined by contours showing pointed lobes directed toward the north and northeast (e.g. Path 2, 1985 and Path 3, 1993 intruded areas). Path 3 which points more towards the East Side Subarea shows a period of "apparent" accelerated advances from 1985 to 1993. Paths 1 and 2 do not suggest periods of accelerated advances.

The outline of the Pressure 180-Foot intrusion front indicates that the northeast edge of the front parallels the fluvial overbank facies near the East Side Subarea (Figure 19). These fluvial overbank materials are fine-grained and serve as a semipermeable barrier of flow from the Pressure to the East Side subareas. Ground water gradients in this area suggest flow from the Pressure to the East Side subarea. However, it is not suggestive in Figure 19 that the seawater intrusion front as defined by the $500 \mathrm{mg} / \mathrm{L}$ mixing with ground water has migrated across to the East Side Subarea.

The center lobes of the main seawater front exhibit bifurcation patterns (Path 4 area, Figure 19) as the successive chloride fronts (contours) intersect the elongate sliver of fluvial overbank materials. Specifically, the 1993, 1997, and 1999 contours are slightly bowed where they encounter the fluvial overbank facies, suggesting a slight retardation in the advancement of the seawater intrusion front. On the other hand, the contours on either side of the overbank sliver/lens are lobate suggesting a relatively higher rate of intrusion. This characteristic of the 


\section{Kennedy/Jenks Consultants}

main front persists only in the area of the overbank lens and as the front advanced further to the southeast and away from the overbank materials as characterized by post 1999 data that the 2001 front assumes a more rounded "nose" pattern without the bifurcation.

The leading edge of the seawater intrusion front in this aquifer is 11,000 feet or about 2 miles from production wells (T14S, R3E, Sections 20 \& 29) in the City of Salinas. The main path of intrusion in the Pressure 180-Foot Aquifer indicates a rate of horizontal migration of $673 \mathrm{ft} / \mathrm{yr}$. We then predict that seawater will impact production wells in the City in about 14 to 16 years.

\subsection{Regional Seawater Intrusion in the Pressure 400-Foot Aquifer}

The advancement of the seawater intrusion front in the Pressure 400-Foot Aquifer through 2001 is shown in Figure 20. These delineations of intruded areas are also presented in Todd 1989 and in the Fort Ord and western Salinas Valley area in Harding ESE (2001). The area of the seawater intrusion and the shape of the front are more irregular than the Pressure 180-Foot Aquifer (Figure 19), although the migration rate within the Pressure 400-Foot Aquifer is slower but comparable (See Table 3, summary data below, and in Todd [1989]).

\section{Discussion}

A distinct lobe of the seawater intrusion front in the Pressure 400-Foot Aquifer extends from Marina to wells 14S/2E-21N01, 14S/2E-21E01, and 14S/2E-21F02 (Figure 20, Path 4).

According to Harding ESE (2001), that lobe advanced nearly one mile between 1997 and 1999 (Table 3, Path $4-1997$ to 1999). The seawater intrusion front in the Pressure 180-Foot Aquifer reached this same area around 1997.

The wells 14S/2E-21N01 and 14S/2E-21E01 were constructed in the mid-1990s, and are constructed in the Pressure 400-Foot Aquifer and sealed through the Pressure 180-Foot Aquifer and higher zones, so Harding ESE (2001) does not consider that improper well construction led to cross-contamination of seawater from the Pressure 180-Foot Aquifer to the Pressure 400-Foot Aquifer.

These three wells are located at the southwest end of Cross-Section C-C', where a possible stratigraphic connection between the Pressure 180-Foot Aquifer and Pressure 400-Foot Aquifer was observed (Figure 20, red dotted wells). Interaquifer communication may have been a factor in the rapid advance, as discussed in the previous Section 6.4.

The seawater intrusion rate as mapped by the chloride front for this same area in 2001 suggests that the advancement has slowed or halted (Table 3); such that, no advancing distance was inferred for the years 2000 and 2001. The resultant aggregate seawater intrusion rate is about $578 \mathrm{ft} / \mathrm{yr}$ (summary data below). This rate is the highest inferred from the five seawater travel paths in the Pressure 400-Foot Aquifer. It is slower than the maximum rate in the Pressure $180-$ Foot zone (673 ft/yr) but comparable. 


\section{Kennedy/Jenks Consultants}

\begin{tabular}{|c|c|c|c|c|c|}
\hline Path \# & 1 & 2 & 3 & 4 & 5 \\
\hline $1944-1995$ & 299 & 442 & 322 & 297 & 570 \\
\hline $1995-2001$ & 650 & 0 & 607 & 1,000 & 0 \\
\hline Cumulative & 416 & 354 & 436 & 578 & 285 \\
\hline
\end{tabular}

The seawater intrusion area expanded to Well 14S/02E-16G01 along Path 3 in years 2000 and 2001 (Figure 20). This expansion over 11 years (Table 3 ) indicates a reduction of intrusion rate (214 ft/yr) back to the typical values of 200 to $300 \mathrm{ft} / \mathrm{yr}$.

The leading edge of the seawater intrusion front in this aquifer is 28,000 feet (about 5 miles) from production wells (T14S, R3E, Sections $20 \& 29$ ) in the City of Salinas. It is unlikely that directly intruded seawater in the Pressure 400-Foot Aquifer from its submarine outcrops will reach the City of Salinas in the near future. At the rate of $578 \mathrm{ft} / \mathrm{yr}$ along Path 4 (the most direct path, Figure 20) to the City of Salinas, it would take an estimated 49 years for the seawater to reach wells in the City.

\subsection{Seawater Intrusion through Natural Aquitard Leakage}

As described in Sections 2.4.4 and 3.1.4, the Pressure 180/400-Foot Aquitard varies in thickness and is very thin or absent in areas near the coast. Potential communication between the Pressure 180-Foot Aquifer and the Pressure 400-Foot Aquifer is of concern due to the potential for mixing of seawater-impacted ground water from the Pressure 180-Foot Aquifer to uncontaminated portions of the Pressure 400-Foot Aquifer.

Historically, ground water elevations in the Pressure 180-Foot Aquifer have been higher (up to 40 plus feet higher) than the piezometric surface of the Pressure 400-Foot Aquifer (Todd, 1989; Harding ESE, 2001). Such a downward hydraulic gradient would bring about ground water movement from the Pressure 180-Foot Aquifer to the Pressure 400-Foot Aquifer. Interaquifer or cross-aquifer contamination is considered to be a significant localized seawater encroachment threat to the current water quality of the Pressure 400-Foot Aquifer for this area. As discussed in Section 3.1.4.1, thin to absent confining clay is observed in portions of six of the seven crosssections (all but G-G', Figure 10).

Based on lithology depicted in the cross-sections and stratigraphic facies discussed in Sections 3 and 4, we conclude that there are localized areas where the aquitard is thin to absent (Figure 10). Data do not support the resemblance of spatially persistent paleo-channels that could produce thin to absent clay layers due to "scouring" during deposition of channel deposits. The most notable thinning of the 180/400-Foot Aquitard can be observed in the subsurface areas of the intersections between Cross-Sections A-A' with E-E', F-F', and G-G' (see red dotted wells in Figure 10) and correlations in cross-sections (Figures 7 through 9). This particular area of aquitard thinning cannot be traced beyond well 14S/03E-33Q01 on the northwest side of Cross-section G-G'.

Two probable scenarios of interaquifer flow is observed in this study; 1) spilling of degraded Pressure 180-Foot ground water into the Pressure 400-Foot zone; and 2) slow downward 


\section{Kennedy/Jenks Consultants}

movement of Pressure 180-Foot ground water through sufficiently thin clay layers of the aquitard into the deeper Pressure 400-Foot zone. Rates for either scenario are estimated to be from 0.1 to 0.25 foot per day dependent of the percentage of fine-grained materials within the interaquifer zones where the aquitard is either discontinuous or very thin (details in Section 6.8). Hence we estimate that seawater reaching the Pressure 180-Foot Aquifer can impact the Pressure 400-Foot Aquifer ground water in one to four years over an interaquifer distance (i.e., the total thickness of the aquitard) of 100 to 500 vertical feet.

\subsection{Hydraulic Communication between the Pressure and East Subareas}

The stratigraphic analysis in this study supports previous findings that the sedimentary characteristics of the aquifer of the East Side Subarea - although heterogeneous and much less correlatable than the Pressure Subarea - are spatially consistent along the length of the Pressure/East Side boundary. The consistency of stratigraphic facies are apparent in CrossSections C-C', D-D', E-E', F-F' and G-G' starting from and northeast of wells 14 S/02E-02C03, 14S/03E-07A01, -09P03, -22D01, and well 14S03E22J50, respectively. These wells and transition zones northeast of them are again presented within the transition zone hatches for both aquifers in Figure 12. We agree with previous studies that the hydraulic conductivities corresponding to the East Side sedimentary facies are at least an order of magnitude lower than those of the aquifers in the Pressure Subarea.

We note that ground water flow direction is from the Pressure Subarea to the East Side Subarea east of the City of Salinas and along the transition zone (Agency 1997). The water levels in the Pressure 180-Foot Aquifer and the Shallow East Side Aquifer range from -20 to -70 feet MSL, respectively.

Water levels in the Pressure 400-Foot Aquifer and the Deep East Side Aquifer range from -20 to -60 feet MSL, respectively (Agency 1997). The stratigraphic cross-sections show evidence of hydraulic communications between these subareas, as discussed in Section 5.4.3.1. These semipermeable and permeable zones of possible flow between the Pressure and East Side are depicted in Figures 19 and 20.

Despite the above noted gradient of flow into the East Side Subarea, it is our opinion that denser saltwater/fresh water mix will not readily flow into the East Side Subarea aquifers, given the aquifer materials of much lower permeabilities in the East Side Subarea. The fact that the edge of the seawater intrusion front is following along the length of the clay-rich overbank facies also supports our conclusion (Figure 19). It is our opinion that the seawater front in the Pressure $180-F o o t$ Aquifer will most likely follow the same path that it is currently taking, and will not breach the overbank facies and reach the areas where permeable facies of the Pressure Subarea are in communication with the permeable facies of the East Side Subarea (i.e., where Cross-Sections D-D' and E-E' intersect the transition zone (Figure 19).

Lastly, the mostly fine-grained materials in stratigraphic facies (Section 4.2) depicted in the Cross-Sections C-C' through G-G' of the East Side Subarea do not support a significant component of vertical flow. The likelihood of downward movement of blended seawater/ground water in the transition zone and in the East Side Subarea is considered low. Hence, the 


\section{Kennedy/Jenks Consultants}

postulated "return flow" scenario is unlikely. The return flow scenario is seawater in the Pressure 180 -Foot Aquifer flowing into the East Side aquifers, migrating downward in the East Side aquifer, and eventually spilling back out into the Pressure 400-Foot Aquifer. This scenario is unlikely or at least the process would take a very long time.

\subsection{Estimated Rates of Seawater Intrusion and Impacts to Water Supply Wells}

The 2001 seawater front in the Pressure 180-Foot Aquifer is about 11,000 feet, or about two miles, from major production wells (T14S, R3E, Section 20 \& 29) in the City of Salinas (Figure 19). Utilizing the two main routes of seawater migration as defined by Paths 4 and 5 (primarily Path 4) in Figure 19, we predict that the seawater intrusion front $(500 \mathrm{mg} / \mathrm{L})$ in the Pressure 180 -Foot Aquifer will impact production wells in the City in about 14 to 16 years from the year 2001 at a horizontal migration rate of $673 \mathrm{ft} / \mathrm{yr}$.

The front along Path 5 is currently 16,000 feet from the southern part of the City of Salinas. This southeastern advancement of seawater suggests an arrival time of 27 years at a horizontal rate of $587 \mathrm{ft} / \mathrm{yr}$. These estimates assume that the current ground water elevations for the Pressure 180-Foot Aquifer are maintained and that the downward hydraulic gradient with the lower aquifer also does not change appreciably. We note that the rate of advancement could increase as seawater approaches the City of Salinas where ground water gradients increase due to pumping.

The travel-time for vertical interaquifer migration of seawater from the Pressure 180-Foot to the Pressure 400-Foot Aquifer is much less than the horizontal migration. The vertical rate of migration from the Pressure 180-Foot Aquifer to the Pressure 400-Foot Aquifer is defined as Darcy's seepage velocity (i.e., linear velocity) of ground water flow. An aggregate vertical seepage rate of $32 \mathrm{ft} / \mathrm{yr}$ was estimated for silty sand with a typical hydraulic conductivity of $0.26 \mathrm{ft} /$ day, an effective formation porosity of 30 percent, and a vertical gradient of $0.1 \mathrm{ft} / \mathrm{ft}$ between the two aquifers. This means that seawater reaching areas of potential interaquifer flow in the Pressure 180-Foot Aquifer (Figures 19 and 20, red dotted wells) can impact the Pressure $400-F o o t$ Aquifer in just an additional one to six years depending on the thickness of the aquitard.

With the above, we view that the predicted horizontal seawater intrusion front arrival times at production wells in the Pressure 180-Foot Aquifer is more significant than the vertical migrations, because: 1) the former must take place before the onset of interaquifer flow and 2) the range of vertical travel time [one to six years] is less important than determining the lateral rates of seawater movements. The much longer travel path and travel time of horizontal advancement over vertical migration of seawater - which has much shorter travel paths of about 200 to 500 vertical feet of interaquifer distance - suggests that the monitoring program should emphasize detection of chloride ions advancing horizontally within each aquifer. We then conclude that the main mechanism of seawater impact of production wells in the Pressure 400-Foot Aquifer involves the combination of regional intrusion into the Pressure 180-Foot Aquifer and the interaquifer flows as blended seawater/fresh water in this zone move down into the former through gaps in the aquitard (Sections 3.1.4 and 6.6). 


\section{Kennedy/Jenks Consultants}

The 2001 seawater front in the Pressure 180-Foot Aquifer is about 14,000 feet, or about two and a half miles, from the major East Side Subarea production wells in Santa Rita (T14S, R3E, Sections 15 and 16). Utilizing the main route of seawater migration as defined by Path 3 (Figure 19), we predict that seawater can impact production wells in this area at the earliest in about 33 years and utilizing a horizontal migration rate of $440 \mathrm{ft} / \mathrm{yr}$. However, results presented in Sections 6.7 and 4.4 do not suggest that the East Side Subarea would be impacted by seawater intrusion in the near future and possibly not at all because of much lower permeability aquifer materials in the East Side slowing flows from the Pressure to the East Side subarea. 
Kennedy/Jenks Consultants

\section{Section 7: Conclusions}

Stratigraphic characteristics of the aquifers, updated interpretations of the ancestral depositional environments, and estimates of seawater intrusion rates are the focus of this study of the northern Salinas Valley hydrostratigraphy. Over 65 documents were reviewed as part of the project scope, and these relevant and significant findings by previous investigators were incorporated into this study.

With the use of a 3-D geographic information system (GIS) and a database of over 700 wells, the result is a three-dimensional (3-D) conceptual model of the interrelated ancestral fluvial and alluvial fan depositional environments that make up the present day ground water bearing zones known as the Pressure 180-Foot Aquifer and the Pressure 400-Foot Aquifer. This depositional model forms the basis for predicting seawater pathways and for estimating seawater intrusion rates.

\subsection{Pressure Subarea Hydrostratigraphy}

Interpretations of seven geologic cross-sections depict two general categories of sediments within the northern Salinas Valley fill: fine-grained aquitards and coarse-grained aquifers. Clays to gravelly clays are classified as aquitards and sands to sand-gravel mixtures are considered to be aquifer materials. Cross-section interpretations corroborate previous findings of the configuration and occurrences of a shallow ground water aquifer perched on top of or located within the SVA. The cross-section interpretations also verify that the tops of the Pressure $180-$ Foot and $400-$ Foot aquifers are generally encountered at -100 feet and -300 feet MSL, respectively. The prominent clay layer, commonly referred to as the Pressure 180/400-Foot Aquitard, is also observed in most of the cross-sections constructed for this study.

The shapes of the sand bodies in the Pressure 180-Foot Aquifer appear to reflect their fluvial depositional origin. That is, the lenticular shapes of the sand bodies observed in cross-sections in the Pressure Subarea reflect deposition in a fluvial channel. The more laterally extensive sand units were formed by the fluvial channel meandering and shifting laterally through time.

In general, the Pressure 400-Foot Aquifer has a larger component of sand and gravel than the Pressure 180-Foot Aquifer, and the sand bodies are more laterally continuous than in the Pressure 180-Foot Aquifer. The more continuous nature of the Pressure 400-Foot Aquifer is interpreted to be the result of frequent meandering of the ancestral Salinas River across the river valley, which resulted in the widespread deposition of sand and gravel. This aquifer zone is more complex than the Pressure 180-Foot Aquifer, with a variable mix of coarse- and finegrained deposits that become more variable in depth and thickness and more discontinuous from southeast to northwest (i.e. in the downstream direction). This spatial transition is likely the remnants of a higher-energy fluvial depositional environment near the present location of the City of Salinas to a lower energy environment toward the Monterey coast.

Localized areas where the Pressure 180/400-Foot Aquitard is thin or absent have been observed in cross-sections and mapped in plan view and these areas are discussed in Section 3.1.4. Areas where this aquitard are absent and where possible direct communication can occur 


\section{Kennedy/Jenks Consultants}

between the Pressure 180-Foot Aquifer and Pressure 400-Foot Aquifer is observed on portions of every cross-section except Cross-Section G-G'. Interaquifer impact is considered to be a significant localized seawater encroachment threat to the current water quality of the Pressure 400-Foot Aquifer for the northern Salinas Valley area.

The most notable area of discontinuities in the aquitard is in the vicinity of Township 14S, Range $3 E$, Sections 20, 29, and 30. In general, we conclude that there are localized areas of aquitard thinning and absence (Figure 10). Data do not support the resemblance of a spatially continuous paleo-channel.

\subsection{East Side Subarea and Transition Zone Hydrostratigraphy}

The transition zone or boundary between the Pressure and East Side Subareas is defined in this study by the transition from predominantly fluvial facies to predominantly alluvial fan facies. By characterizing the sedimentary facies and stratigraphic architecture of the transition zone, we have filled in the missing link between the Pressure and East Side Subarea hydrogeology and developed models of the paleo-depositional environments.

The fluvially generated Pressure 180-Foot and Pressure 400-Foot Aquifers of the Pressure Subarea are not observed in the East Side Subarea. The sand and gravel beds of the East Side Subarea are generally thinner and less continuous than in the Pressure Subarea. This study corroborates previous investigations that the East Side stratigraphy does not correlate well between boreholes. We conclude and agree with other investigators that the gravel and sand deposits represent complex remnants of streams feeding the alluvial fans, which resulted in a complex record of sediment deposition and erosion.

Blue clay beds form the principal aquicludes and aquitards in the Pressure Subarea, are rarely observed within the East Side Subarea. Correlations completed in this study suggest that the blue clay spreads through the northern Salinas Valley and onlapped the alluvial fans on the east side of the Valley.

The sedimentary facies characteristics of the East Side Subarea suggest that the wells in this area would have lower yields, and that the hydraulic conductivities are at least an order of magnitude lower than the sediments comprising the Pressure 180-Foot Aquifer zone of the Pressure Subarea. We also postulate that seawater intrusion would occur at a substantially slower rate in the East Side Subarea than has been observed in the Pressure Subarea.

\subsection{Regional Seawater Intrusion}

The first condition for seawater intrusion in the northern Salinas Valley area is that the aquifers are in direct hydraulic contact between the aquifers and the sea. Accordingly, there evidence of submarine outcrops for both aquifers in the northwest end of Cross-Section A-A'. The secondary condition for seawater mixing or intrusion in the fresh water aquifers is that ground water levels in both aquifers are below sea level with a developing landward ground water gradient recorded since the 1930s. 


\section{Kennedy/Jenks Consultants}

The Pressure 180-Foot seawater intrusion front noticeably follows the trend of the fluvial channel facies, and is confined by the band of the less permeable overbank facies (Figure 19). These fluvial overbank deposits are fine grained and serve as a semipermeable barrier of flow from the Pressure to the East Side subarea (Section 5). Ground water gradients in this area suggest a potential for flow from the Pressure to the East Side subarea. However, we conclude that the seawater intrusion front has not migrated across to the East Side Subarea based on chloride concentrations. We note that the water levels have risen in the CSIP service area and that the corresponding changes in hydraulic gradient in this specific area have not been accounted for in this analysis.

The 2001 seawater front in the Pressure 180-Foot Aquifer is about two miles from potable water supply wells (T14S, R3E, Section 20 \& 29) in the City of Salinas (Figure 19). We predict that seawater in the Pressure 180-Foot Aquifer will impact production wells in the City in about 14 to 16 years at a horizontal migration rate of $673 \mathrm{ft} / \mathrm{yr}$. These estimates assume that the current ground water elevations for the Pressure 180-Foot Aquifer are maintained and that the downward hydraulic gradient with the lower aquifers also does not change appreciably.

The leading edge of the seawater front in the Pressure 400-Foot Aquifer is about five miles from production wells (T14S, R3E, Sections 20 \& 29) in the City of Salinas. It is unlikely that seawater that has intruded directly from submarine outcrops into the Pressure 400-Foot Aquifer will reach the City in the near future; the travel time is estimated to be 49 years based on a rate of 578 $\mathrm{ft} / \mathrm{yr}$. We do not anticipate abrupt accelerated advancement of seawater south of Castroville and in the Marina / Fort Ord area, where the two most prominent seawater intrusion fronts in this aquifer zone have been recorded to-date. We conclude that although regional seawater intrusion mechanism for the Pressure 400-Foot Aquifer is of importance for continued monitoring, it is more likely that in the City of Salinas this aquifer and its production wells will be impacted by interaquifer flow from the Pressure 180-Foot Aquifer to the Pressure 400-Foot Aquifer similar to that observed in the Fort Ord area. However, this scenario requires seawater in the Pressure 180-Foot Aquifer to advance to areas of mapped aquitard discontinuities, and for such areas in the City of Salinas, the predicted impact time is about 20 years to potable water wells. 
Kennedy/Jenks Consultants

\section{Section 8: Recommendations}

These recommendations are made based on the analyses of hydrostratigraphic sections and the evaluation of seawater intrusion areas and rates of intrusion expansion. We also reviewed suggestions from previous studies and included those that are relevant to the objective of this study and in characterizing seawater intrusion in the northern Salinas Valley. Recommendations listed are not exhaustive and in no order of importance.

1. Continue to perform detailed evaluations of ground water chemistry signature to distinguish the origin and mechanism of seawater and fresh ground water mixing; i.e. regionally intruded seawater versus interaquifer contamination and well leakage. This can be done (as performed in Todd 1989) by use of Trilinear diagrams of cation and anion distributions at specific well locations. This should be done in additional to chloride spatial and temporal trend analyses.

2. Map vertical hydraulic gradients of ground water in the Pressure 180-Foot and Pressure 400 -Foot Aquifers. Changes in ground water gradient provide an indication of the degree of confinement of the lower water bearing zone by the Pressure 180/400 Aquitard. This in turn can infer the relative and spatial variation of thicknesses of the aquitard. This approach will depend on the availability of data and well completion records. These gradient maps should then be compared to hydrostratigraphic facies maps in this and previous studies.

3. Based on Recommendation 2 mentioned above; a) estimate the spatial distribution of ground water leakages (Darcy's flux) across the Pressure/East Side boundary, b) map the distribution of interaquifer flow quantities, and c) estimate and map the quantity of well leakage where data are available.

4. Continue water quality sampling - specifically chloride and total dissolved solids - in both aquifers to aid in modeling the future pattern of seawater and to distinguish mechanisms of intrusion and seawater/fresh water mixing. Emphasis should be given to locations of triggermonitoring wells along the seawater intrusion pathways as discussed in Section 6.

5. Construct a three-dimensional model based on the hydrostratigraphic analysis reported in this study. The amount of data used in this study and its findings merit the development of a solid three dimensional (3-D) model of: a) inferred permeabilities; b) lithology; and c) depiction of ground water quality and elevations. The best approach to accomplish this is to digitally parameterize (populate) a 3-D numerical matrix based on correlations in crosssections. This 3-D model (matrix) can be used to calculate (map) flows and quantify ground water volumes for each aquifer or for separate compartments like those used in evaluating the seawater pathways discussed in Section 6.

6. Use dual-density computer model to evaluate flow and seawater mixing with fresh water as part of overall water resources planning. A computer model will also be a preferred method in providing more quantitative predictions of intrusion rates over the calculations in this report, particularly as the seawater front approaches the City of Salinas where ground water gradient and vertical migration magnitudes are greater. 
7. Continue to update the Agency WRAIMS database in terms of ground water quality, elevations, and lithologic information. WRAIMS should be used to update the lithologic cross-sections whenever new data are available for reevaluation of the area's hydrostratigraphy.

WRAIMS should be upgraded with a computerized hydrostratigraphic analysis tool to allow for more efficient review of cross-sections and ground water data. The most cost-effective solution is to upgrade WRAIMS with a cross-section construction tool as an extension to the WRAIMS GIS capability.

8. Continue to evaluate and redraw the boundary between the Pressure and East Side Subareas based on water quality, hydrostratigraphic understandings, and updated interpretations of the depositional environment as reported in this study. 


\section{Section 9: Limitations}

This report, consisting of professional opinions and recommendations, has been made in accordance with generally accepted principles and practices in the field of geology and hydrogeology. The interpretation of geologic conditions within the study area is based on information collected during the construction of water wells. The development of seven (7) sections distributed throughout the study area was included in the scope of work for this report.

The locations for the cross-sections were selected to provide a generalized representation of geologic conditions within the study area. The geologic cross-sections developed for this report are based on information from the wells shown on the cross-sections. The geologic information shown between the wells on each cross-section is an interpretation based on professional opinion and may not be an accurate representation of subsurface conditions between wells.

Due to changes in geologic conditions within the study area, the information from the geologic cross-sections in this report should not be used as the means for determining site conditions for geographic areas not included in a cross-section. Our data interpretation and data presented herein do not provide a warranty as to the conditions that may exist beneath the entire study area. It is possible that variations in lithologic conditions and depth to ground water could exist at the site and may require additional studies, consultation, and possible report revisions. 


\section{Section 10: References}

Brown, Dick. 1986. Geologic Study of 13S/2E and 14S/2E of Salinas Valley, Draft Report.

Dupre, W.R. 1990. Quaternary Geology of the Monterey Bay Region, California in Pacific Section of the American Association of Petroleum Geologists: Geology and Tectonics of the Central California Coast Region Volume and Guidebook, pp. 185 - 191.

Freeze, Allan R. and Cherry, John A. 1979. Groundwater. Prentice-Hall Inc.

Greene, H. G. 1970. Geology of Southern Monterey Bay and its Relationship to the Ground Water Basin and Salt Water Intrusion. U.S. Geological Survey Open-File Report, 50 p.

Greene, H. G. 1977. Geology of Southern Monterey Bay Region. U.S. Geological Survey OpenFile Report 77-718, $347 \mathrm{p}$.

Hall, P. 1992. Selected Geological Cross-Sections in the Salinas Valley Using GEOBASE ${ }^{\text {TM }}$. Prepared for the Monterey County Water Resources Agency.

Harding ESE. 2001. Final Report Hydrogeologic Investigation of the Salinas Valley Basin in the Vicinity of Fort Ord and Marina Salinas Valley, California.

J.M. Montgomery Engineers, Inc. 1993. Salinas Basin Ground Water Model. Draft report to the Monterey County Water Resources Agency.

Leedshill-Herkenhoff, Inc. 1984. Salinas Valley Seawater Intrusion Study Preliminary Task Report.

Manning, J. C. 1963. Resume of Ground Water Hydrology in Salinas Valley, California, in American Association of Petroleum Geologists - Society of Economic Paleontologists and Mineralogists Annual Spring Field Trip Guidebook: Geology of the Salinas Valley and the San Andreas Fault, p. 106-109.

Monterey County Flood Control and Water Conservation District (MCFCWCD). 1960. Salinas Valley Geologic Investigation.

Monterey County Flood Control and Water Conservation District (MCFCWCD). 1968. Investigation of an East Side Canal Project, Salinas Valley.

Monterey County Water Resources Agency (Agency). 1997. Water Resources Data Report Water Year 1994-1995.

Staal, Gardner, and Dunne, Inc. (SGD). 1990. Hydrogeologic Study - Rancho San Juan ADC Area. Report prepared for the Monterey County Flood Control and Water Conservation District. 
Staal, Gardner, and Dunne, Inc. (SGD). 1993. Hydrogeologic Study: Salinas Valley Ground Water Basin, Seawater Intrusion Delineation/Monitoring Well Construction Program, Pressure 180-Foot Aquifer, Salinas Area, California. Prepared for Monterey County Water Resources Agency.

State of California, Department of Public Works, Division of Water Resources (DWR). 1946. Bulletin No. 52, Salinas Basin Investigation.

State of California, Department of Public Works, Division of Water Resources (DWR). 1970. Sea Water Intrusion Lower Salinas Valley Progress Report 1968-1969.

State of California, Department of Public Works, Division of Water Resources (DWR). 1973. Sea Water Intrusion Lower Salinas Valley.

Tinsley, J.C. III. 1975. Quaternary Geology of Northern Salinas Valley, Monterey County, California. Ph.D. Dissertation, Stanford University.

Thorup, Richard R. 1976. Report on Castroville Irrigation Project Deep Test Hole And Freshwater Bearing Strata Below the Pressure 400-Foot Aquifer, Salinas Valley, CA.

Todd, David Keith. 1989. Initial Assessment of Seawater Intrusion by Well Leakage into the Pressure 400-Foot Aquifer, Castroville Area.

Todd, David Keith. 1989. Sources of Saline Intrusion in the Pressure 400-Foot Aquifer, Castroville Area, California. 
Tables 
Kennedy/Jenks Consultants

Table 1: $\quad$ List of Well Logs Used in Cross-Sections

\begin{tabular}{|c|c|c|c|c|c|c|}
\hline Well Name & Easting & Northing & $\begin{array}{l}\text { Cross- } \\
\text { Section }\end{array}$ & $\begin{array}{c}\text { Elevation } \\
\text { (feet } \\
\left.\text { MSL }^{(a)}\right)\end{array}$ & Log Date & Log Source \\
\hline 13S/02E-31L01 & 5744481 & 2170637 & A-A' & 32.81 & no date on log & WRAIMS-excel \\
\hline 14S/02E-05G02 & 5751035 & 2166106 & A-A' & 9.84 & $1 / 22 / 1959$ & WRAIMS-excel \\
\hline 14S/02E-05K01 & 5750118 & 2165251 & A-A' & 9.84 & $8 / 30 / 1955$ & WRAIMS-excel \\
\hline 14S/02E-05R03 & 5752345 & 2163500 & A-A' & 9.84 & $7 / 1 / 1964$ & WRAIMS-excel \\
\hline 14S/02E-08A01 & 5751809 & 2162218 & A-A' & 13.12 & 10/5/1957 & WRAIMS-excel \\
\hline 14S/02E-09D04 & 5753019 & 2162820 & $A-A^{\prime}$ & 9.84 & no date available & WRAIMS-excel \\
\hline 14S/02E-09K02 & 5756034 & 2161092 & A-A' & 13.12 & 10/17/1973 & WRAIMS-excel \\
\hline 14S/02E-09L02 & 5754726 & 2161137 & A-A' & 9.84 & 9/21/1956 & WRAIMS-excel \\
\hline 14S/02E-12E01 & 5772580 & 2145645 & $A-A^{\prime}$ & 32.81 & no date on log & $\begin{array}{l}\text { MCWRA Fax - } \\
\text { hardcopy }\end{array}$ \\
\hline 14S/02E-14L03 & 5764606 & 2154424 & A-A' & 19.69 & $8 / 1 / 1990$ & MCWRA mail 2 \\
\hline 14S/02E-15A01 & 5762051 & 2156980 & $A-A^{\prime}$ & 19.69 & $5 / 9 / 1978$ & MCWRA mail 2 \\
\hline 14S/02E-23H04 & 5767644 & 2150094 & $A-A^{\prime}$ & 29.53 & 10/1/1962 & $\begin{array}{l}\text { MCWRA Fax - } \\
\text { hardcopy }\end{array}$ \\
\hline 14S/02E-24J03 & 5772957 & 2148630 & A-A' & 29.53 & $12 / 1 / 1957$ & WRAIMS-excel \\
\hline 14S/02E-24P02 & 5773211 & 2147410 & $A-A^{\prime}$ & 42.65 & $11 / 13 / 1961$ & $\begin{array}{l}\text { MCWRA Fax - } \\
\text { hardcopy }\end{array}$ \\
\hline 14S/03E-29Q01 & 5780097 & 2141346 & A-A' & 39.37 & $8 / 26 / 1977$ & CWS fax \\
\hline 14S/03E-33Q01 & 5786107 & 2137635 & A-A' & 49.22 & $3 / 16 / 1961$ & CWS fax \\
\hline 15S/03E-03C01 & 5790880 & 2135425 & A-A' & 59.06 & no date on log & WRAIMS-excel \\
\hline 15S/03E-03K02 & 5792868 & 2132488 & $A-A^{\prime}$ & 62.34 & 6/1/1954 & WRAIMS-excel \\
\hline 15S/03E-03R02 & 5793181 & 2130514 & A-A' & 59.06 & $7 / 1 / 1963$ & WRAIMS-excel \\
\hline APN-227021014 & 5766831 & 2153969 & $A-A^{\prime}$ & 19.69 & $1 / 3 / 2001$ & Post 1998 fax \\
\hline 13S/02E-36F01 & 5768169 & 2170823 & C-C' & 9.84 & $12 / 28 / 1949$ & WRAIMS-excel \\
\hline 14S/02E-02C03 & 5765130 & 2167461 & C-C' & 68.9 & $7 / 16 / 1987$ & $\begin{array}{l}\text { MCWRA Fax - } \\
\text { hardcopy }\end{array}$ \\
\hline 14S/02E-02E02 & 5763845 & 2166608 & C-C' & 45.93 & $11 / 21 / 1961$ & WRAIMS-excel \\
\hline 14S/02E-03K02 & 5760546 & 2164416 & C-C' & 19.69 & $2 / 5 / 1982$ & WRAIMS-excel \\
\hline 14S/02E-03R02 & 5762516 & 2163909 & C-C' & 19.69 & 9/15/1992 & MCWRA mail 2 \\
\hline 14S/02E-10H01 & 5761487 & 2160777 & C-C' & 19.69 & 9/11/1985 & WRAIMS-excel \\
\hline 14S/02E-15P01 & 5758703 & 2153476 & C-C' & 45.93 & 9/5/1965 & WRAIMS-excel \\
\hline 14S/02E-16A02 & 5757230 & 2156179 & C-C' & 19.69 & 10/17/1973 & WRAIMS-excel \\
\hline 14S/02E-16G01 & 5755861 & 2155827 & C-C' & 19.69 & no date available & WRAIMS-excel \\
\hline 14S/02E-16H01 & 5756685 & 2155404 & C-C' & 19.69 & $5 / 11 / 1976$ & WRAIMS-excel \\
\hline 14S/02E-21E01 & 5752647 & 2150365 & C-C' & 101.71 & $8 / 23 / 1997$ & Fort Ord - excel \\
\hline 14S/02E-21F02 & 5753622 & 2151834 & C-C' & 26.25 & 10/22/1956 & WRAIMS-excel \\
\hline 14S/02E-21N01 & 5752593 & 2147797 & C-C' & 134.52 & no date available & Fort Ord - excel \\
\hline 14S/02E-28C01 & 5753288 & 2145538 & C-C' & 45.93 & no date available & Fort Ord - excel \\
\hline APN-133013001 & 5768220 & 2173603 & C-C' & 22.97 & $8 / 9 / 2002$ & Post 1998 fax \\
\hline
\end{tabular}


Kennedy/Jenks Consultants

Table 1: $\quad$ List of Well Logs Used in Cross-Sections

\begin{tabular}{|c|c|c|c|c|c|c|}
\hline Well Name & Easting & Northing & $\begin{array}{l}\text { Cross- } \\
\text { Section }\end{array}$ & $\begin{array}{c}\text { Elevation } \\
\text { (feet } \\
\left.\text { MSL }^{(a)}\right)\end{array}$ & Log Date & Log Source \\
\hline 13S/03E-32Q01 & 5782441 & 2168308 & D-D' & 144.36 & $6 / 21 / 1951$ & WRAIMS-excel \\
\hline 14S/02E-12Q01 & 5771550 & 2157101 & D-D' & 39.37 & $1 / 1 / 1938$ & WRAIMS-excel \\
\hline 14S/02E-13F02 & 5770982 & 2154734 & D-D' & 39.37 & 6/12/1993 & $\begin{array}{l}\text { MCWRA Fax - } \\
\text { hardcopy }\end{array}$ \\
\hline 14S/02E-13G01 & 5772059 & 2155494 & D-D' & 49.22 & 9/6/1978 & $\begin{array}{l}\text { MCWRA Fax - } \\
\text { hardcopy }\end{array}$ \\
\hline 14S/02E-13P50 & 5770438 & 2152221 & D-D' & 52.5 & no date on log & $\begin{array}{l}\text { MCWRA Fax - } \\
\text { hardcopy }\end{array}$ \\
\hline 14S/02E-25D03 & 5768820 & 2146345 & D-D' & 29.53 & 9/18/1973 & $\begin{array}{l}\text { MCWRA Fax - } \\
\text { hardcopy }\end{array}$ \\
\hline 14S/02E-25E02 & 5768033 & 2145602 & D-D' & 29.53 & $12 / 3 / 1963$ & $\begin{array}{l}\text { MCWRA Fax - } \\
\text { hardcopy }\end{array}$ \\
\hline 14S/02E-26A06 & 5767267 & 2145928 & D-D' & 29.53 & $12 / 20 / 1966$ & $\begin{array}{l}\text { MCWRA Fax - } \\
\text { hardcopy }\end{array}$ \\
\hline 14S/02E-26J03 & 5766831 & 2143917 & D-D' & 32.81 & $6 / 30 / 1978$ & $\begin{array}{l}\text { MCWRA Fax - } \\
\text { hardcopy }\end{array}$ \\
\hline 14S/03E-05B02 & 5782001 & 2165414 & D-D' & 118.12 & no date available & WRAIMS-excel \\
\hline 14S/03E-05T55 & 5781854 & 2164713 & D-D' & 114.83 & 4/1/1976 & WRAIMS-excel \\
\hline 14S/03E-06J02 & 5778772 & 2164188 & D-D' & 88.59 & $3 / 24 / 1947$ & WRAIMS-excel \\
\hline 14S/03E-07A01 & 5778411 & 2161662 & D-D' & 88.59 & 10/1/1937 & WRAIMS-excel \\
\hline 14S/03E-07K51 & 5777551 & 2159616 & D-D' & 36.09 & 11/1/1992 & WRAIMS-excel \\
\hline 14S/03E-07L01 & 5775637 & 2159478 & D-D' & 68.9 & $3 / 14 / 1960$ & WRAIMS-excel \\
\hline 14S/03E-07P02 & 5775832 & 2157899 & D-D' & 45.93 & 9/15/1982 & MCWRA mail 2 \\
\hline APN-227062005 & 5768188 & 2147399 & D-D' & 36.09 & $11 / 13 / 2002$ & Post 1998 fax \\
\hline APN-414013005 & 5766469 & 2145232 & D-D' & 32.81 & $7 / 28 / 2000$ & Post 1998 fax \\
\hline APN-414021010 & 5763762 & 2140668 & D-D' & 32.81 & 9/7/2002 & Post 1998 fax \\
\hline 14S/03E-09B01 & 5788060 & 2161157 & E-E' & 118.12 & no date available & WRAIMS-excel \\
\hline 14S/03E-09P03 & 5786267 & 2157511 & E-E' & 91.87 & $3 / 11 / 1971$ & CWS fax \\
\hline 14S/03E-10N01 & 5789946 & 2157068 & E-E' & 141.08 & no date on log & WRAIMS-excel \\
\hline 14S/03E-16E02 & 5785346 & 2155109 & E-E' & 98.43 & 2/1/1991 & WRAIMS-excel \\
\hline 14S/03E-16M01 & 5785214 & 2153016 & E-E' & 91.87 & $2 / 1 / 1991$ & CWS fax \\
\hline 14S/03E-20C01 & 5780967 & 2149710 & E-E' & 62.34 & 9/16/1960 & CWS fax \\
\hline 14S/03E-20M02 & 5779875 & 2147880 & E-E' & 55.78 & $8 / 1 / 1978$ & CWS fax \\
\hline 14S/03E-21E03 & 5784456 & 2149594 & E-E' & 78.74 & $9 / 1 / 1974$ & CWS fax \\
\hline 14S/03E-29C01 & 5780635 & 2145540 & E-E' & 59.06 & $4 / 27 / 1981$ & WRAIMS-excel \\
\hline 14S/03E-29F03 & 5780127 & 2144557 & E-E' & 39.37 & $3 / 31 / 1986$ & CWS fax \\
\hline 14S/03E-31B01 & 5776302 & 2140048 & E-E' & 39.37 & $11 / 13 / 1931$ & MCWRA mail 2 \\
\hline 14S/03E-31L01 & 5775962 & 2138054 & E-E' & 42.65 & $5 / 15 / 1973$ & WRAIMS-excel \\
\hline 14S/03E-31P01 & 5775576 & 2136362 & E-E' & 39.37 & 3/7/1980 & CWS fax \\
\hline
\end{tabular}


Kennedy/Jenks Consultants

Table 1: $\quad$ List of Well Logs Used in Cross-Sections

\begin{tabular}{|c|c|c|c|c|c|c|}
\hline Well Name & Easting & Northing & $\begin{array}{l}\text { Cross- } \\
\text { Section }\end{array}$ & $\begin{array}{c}\text { Elevation } \\
\text { (feet } \\
\left.\text { MSL }^{(a)}\right)\end{array}$ & Log Date & Log Source \\
\hline 15S/02E-01H02 & 5772322 & 2134327 & E-E' & 36.09 & $12 / 1 / 1960$ & MCWRA mail 2 \\
\hline 15S/02E-01K01 & 5769536 & 2130429 & E-E' & 36.09 & $1 / 1 / 1935$ & WRAIMS-excel \\
\hline $15 \mathrm{~S} / 02 \mathrm{E}-12 \mathrm{~A} 01$ & 5772139 & 2129923 & E-E' & 39.37 & $5 / 5 / 1960$ & WRAIMS-excel \\
\hline 15S/03E-06D02 & 5773377 & 2135183 & E-E' & 36.09 & $11 / 15 / 1958$ & WRAIMS-excel \\
\hline APN-211181003 & 5790138 & 2160295 & E-E' & 141.08 & $8 / 29 / 2002$ & Post 1998 fax \\
\hline 14S/03E-10B01 & 5793892 & 2161981 & F-F' & 167.33 & $11 / 9 / 1957$ & WRAIMS-excel \\
\hline 14S/03E-10R02 & 5794256 & 2157152 & F-F' & 137.8 & $12 / 23 / 1954$ & WRAIMS-excel \\
\hline 14S/03E-15G01 & 5792906 & 2154872 & F-F' & 131.24 & no date on log & WRAIMS-excel \\
\hline 14S/03E-15K03 & 5792845 & 2152868 & F-F' & 108.27 & $1 / 1 / 1949$ & WRAIMS-excel \\
\hline 14S/03E-15P01 & 5790853 & 2151825 & F-F' & 101.71 & no date on log & WRAIMS-excel \\
\hline 14S/03E-21L01 & 5785649 & 2148130 & F-F' & 78.74 & $1 / 21 / 1950$ & WRAIMS-excel \\
\hline 14S/03E-22D01 & 5790071 & 2152141 & F-F' & 98.43 & $11 / 1 / 1975$ & CWS fax \\
\hline 14S/03E-22E51 & 5790077 & 2149259 & F-F' & 82.03 & $4 / 5 / 2002$ & CWS fax \\
\hline 14S/03E-28F02 & 5786239 & 2144995 & F-F' & 36.09 & $12 / 10 / 1950$ & WRAIMS-excel \\
\hline 14S/03E-28M02 & 5784086 & 2142400 & F-F' & 49.22 & no date available & WRAIMS-excel \\
\hline 14S/03E-28N03 & 5784086 & 2142499 & F-F' & 45.93 & $5 / 17 / 1955$ & Hardcopy-Geobase \\
\hline 14S/03E-32N04 & 5779239 & 2137271 & F-F' & 45.93 & $3 / 25 / 1966$ & WRAIMS-excel \\
\hline 15S/03E-06R01 & 5777305 & 2130632 & F-F' & 39.37 & $2 / 15 / 1948$ & WRAIMS-excel \\
\hline 15S/03E-07F02 & 5773983 & 2128798 & F-F' & 39.37 & 3/1/1965 & WRAIMS-excel \\
\hline 15S/03E-18C02 & 5774492 & 2124373 & F-F' & 42.65 & 4/1/1954 & WRAIMS-excel \\
\hline 15S/03E-07K51 & 5776189 & 2128628 & F-F' & 39.37 & $6 / 22 / 2000$ & Post 1998 fax \\
\hline 14S/03E-11E50 & 5795166 & 2159299 & F-F' & 154.21 & 7/8/1999 & Post 1998 fax \\
\hline 14S/03E-11E51 & 5794824 & 2159292 & F-F' & 154.21 & $1 / 6 / 1999$ & Post 1998 fax \\
\hline 14S/03E-02L50 & 5796224 & 2164437 & F-F' & 170.61 & $6 / 6 / 2002$ & Post 1998 fax \\
\hline 14S/03E-22A01 & 5795569 & 2150706 & G-G' & 101.71 & 10/27/1955 & WRAIMS-excel \\
\hline 14S/03E-28B02 & 5791415 & 2142310 & G-G' & 59.06 & $5 / 28 / 1962$ & WRAIMS-excel \\
\hline 14S/03E-33G01 & 5787201 & 2139358 & G-G' & 39.37 & $2 / 28 / 1935$ & CWS fax \\
\hline 14S/03E-34C01 & 5790510 & 2140541 & G-G' & 65.62 & $4 / 26 / 1968$ & CWS fax \\
\hline 15S/03E-04K03 & 5785725 & 2131199 & G-G' & 55.78 & $1 / 9 / 1960$ & WRAIMS-excel \\
\hline 15S/03E-04Q01 & 5786592 & 2131145 & G-G' & 59.06 & $3 / 30 / 1971$ & CWS fax \\
\hline 15S/03E-04T50 & 5786416 & 2132795 & G-G' & 55.78 & no date available & WRAIMS-excel \\
\hline 15S/03E-08B04 & 5780773 & 2128730 & G-G' & 49.22 & $10 / 16 / 1978$ & WRAIMS-excel \\
\hline 15S/03E-08F05 & 5780190 & 2127283 & G-G' & 49.22 & 7/6/1962 & WRAIMS-excel \\
\hline 15S/03E-09E03 & 5784552 & 2127792 & G-G' & 49.22 & $12 / 23 / 1946$ & WRAIMS-excel \\
\hline 15S/03E-17B03 & 5781255 & 2123885 & G-G' & 49.22 & $5 / 1 / 1979$ & WRAIMS-excel \\
\hline 15S/03E-17G01 & 5780643 & 2122747 & G-G' & 49.22 & 10/15/1982 & WRAIMS-excel \\
\hline 15S/03E-17M01 & 5778444 & 2122174 & G-G' & 39.37 & $6 / 23 / 1955$ & WRAIMS-excel \\
\hline 14S/03E-22J50 & 5793668 & 2146642 & G-G' & 49.22 & $11 / 18 / 1999$ & Post 1998 fax \\
\hline
\end{tabular}


Kennedy/Jenks Consultants

Table 1: $\quad$ List of Well Logs Used in Cross-Sections

\begin{tabular}{|c|c|c|c|c|c|c|}
\hline Well Name & Easting & Northing & $\begin{array}{l}\text { Cross- } \\
\text { Section }\end{array}$ & $\begin{array}{c}\text { Elevation } \\
\text { (feet } \\
\left.\text { MSL }^{(a)}\right) \\
\end{array}$ & Log Date & Log Source \\
\hline 13S/02E-28B01 & 5755623 & 2177909 & B-B' & 36.09 & $12 / 6 / 1960$ & MCWRA mail \\
\hline 13S/02E-28E01 & 5752984 & 2176435 & B-B' & 32.81 & 9/14/1990 & MCWRA mail \\
\hline 13S/02E-28M02 & 5753447 & 2175998 & B-B' & 32.81 & $5 / 26 / 1986$ & MCWRA mail \\
\hline 13S/02E-29J01 & 5751472 & 2175785 & B-B' & 32.81 & $5 / 1 / 1957$ & MCWRA mail \\
\hline 13S/02E-32E03 & 5748693 & 2171792 & B-B' & 32.81 & no date available & WRAIMS-excel \\
\hline 13S/02E-32E05 & 5748672 & 2171138 & B-B' & 32.81 & 10/15/1984 & WRAIMS-excel \\
\hline 13S/02E-32J03 & 5752339 & 2171082 & B-B' & 32.81 & $8 / 11 / 1962$ & MCWRA mail \\
\hline 13S/02E-32M02 & 5748673 & 2170965 & B-B' & 32.81 & $12 / 5 / 1984$ & MCWRA mail \\
\hline 13S/02E-32P01 & 5749690 & 2170011 & B-B' & 32.81 & no date available & WRAIMS-excel \\
\hline 14S/01E-13J02 & 5741217 & 2154079 & B-B' & 26.25 & no date available & Fort Ord - excel \\
\hline 14S/01E-24L05 & 5738662 & 2149679 & B-B' & 49.22 & no date available & Fort Ord - excel \\
\hline 14S/01E-24L53 & 5738254 & 2149250 & B-B' & 32.81 & $1 / 22 / 1996$ & MCWRA mail \\
\hline 14S/02E-06J03 & 5747145 & 2165043 & B-B' & 9.84 & $5 / 3 / 1948$ & MCWRA mail \\
\hline 14S/02E-06L01 & 5743814 & 2165454 & B-B' & 9.84 & 11/12/1976 & WRAIMS-excel \\
\hline 14S/02E-06R02 & 5746853 & 2163230 & B-B' & 9.84 & $2 / 25 / 1948$ & MCWRA mail \\
\hline 14S/02E-07A01 & 5747019 & 2162663 & B-B' & 9.84 & 9/19/1974 & MCWRA mail \\
\hline 14S/02E-07A02 & 5747125 & 2161693 & B-B' & 9.84 & 2/1/1982 & MCWRA mail \\
\hline 14S/02E-07F02 & 5743496 & 2160715 & B-B' & 9.84 & no date available & Fort Ord - excel \\
\hline 14S/02E-07L04 & 5743780 & 2159328 & B-B' & 9.84 & $8 / 23 / 1983$ & Fort Ord - excel \\
\hline 14S/02E-07L05 & 5743785 & 2160381 & B-B' & 9.84 & $5 / 6 / 1988$ & Fort Ord - excel \\
\hline 14S/02E-18E01 & 5742787 & 2156369 & B-B' & 6.56 & $7 / 6 / 1974$ & Fort Ord - excel \\
\hline 14S/02E-10M02 & 5757983 & 2159568 & $A-A^{\prime}, C-C^{\prime}$ & 22.97 & 10/18/1965 & WRAIMS-excel \\
\hline 14S/02E-15B01 & 5760095 & 2156465 & A-A',C-C' & 36.09 & $5 / 26 / 1982$ & WRAIMS-excel \\
\hline 14S/02E-15C02 & 5759335 & 2157212 & A-A',C-C' & 32.81 & $6 / 20 / 1978$ & MCWRA mail 2 \\
\hline 14S/02E-23J50 & 5767802 & 2148880 & A-A',D-D' & 29.53 & 10/1/1990 & $\begin{array}{l}\text { MCWRA Fax - } \\
\text { hardcopy }\end{array}$ \\
\hline 14S/02E-24D50 & 5768924 & 2151344 & A-A',D-D' & 32.81 & 9/28/1995 & $\begin{array}{l}\text { MCWRA Fax - } \\
\text { hardcopy }\end{array}$ \\
\hline 14S/02E-24E01 & 5768287 & 2150314 & A-A',D-D' & 29.53 & $5 / 25 / 1951$ & WRAIMS-excel \\
\hline 14S/03E-29N02 & 5778559 & 2142474 & A-A',E-E' & 39.37 & $5 / 20 / 1959$ & CWS fax \\
\hline 14S/03E-28N01 & 5783795 & 2140837 & A-A',F-F & 49.22 & $6 / 16 / 1948$ & MCWRA mail 2 \\
\hline 14S/03E-32F01 & 5779603 & 2139186 & A-A',F-F & 49.22 & no date available & WRAIMS-excel \\
\hline 14S/03E-32H02 & 5782760 & 2137999 & A-A',F-F' & 52.5 & no date on log & WRAIMS-excel \\
\hline 13S/02E-32N01 & 5747285 & 2169133 & A-A',B-B' & 32.81 & $5 / 1 / 1949$ & MCWRA mail \\
\hline 14S/02E-05C03 & 5749012 & 2167112 & A-A',B-B' & 9.84 & 4/14/1988 & MCWRA mail \\
\hline 14S/02E-05F04 & 5749767 & 2166855 & A-A',B-B' & 9.84 & $3 / 26 / 1954$ & WRAIMS-excel \\
\hline
\end{tabular}

(a) $\mathrm{MSL}=$ Mean Sea Level 
Kennedy/Jenks Consultants

Table 2: $\quad$ Sedimentary and Hydraulic Characteristics of the Pressure and East Side Subareas

\begin{tabular}{lll}
\hline Characteristics & Pressure Subarea & East Side Subarea \\
\hline Depositional Environment & Fluvial & Alluvial Fan \\
\hline Predominant Sedimentary Facies & Sand and gravel & $\begin{array}{l}\text { Clay with discontinuous sand and } \\
\text { gravel deposits }\end{array}$ \\
\hline $\begin{array}{l}\text { Stratigraphic Architecture of } \\
\text { Permeable Units }\end{array}$ & $\begin{array}{l}\text { Relatively thick and continuous } \\
\text { (especially in the Pressure 400-Foot } \\
\text { Aquifer) }\end{array}$ & $\begin{array}{l}\text { Discontinuous } \\
\text { Hydraulic Connectivity }\end{array}$ \\
$\begin{array}{lll}\text { Higher } & \text { Lower (at least one order of } \\
& \text { magnitude lower than the Pressure } \\
\text { Subarea) }\end{array}$ \\
\hline Ground Water Velocities & Faster & $\begin{array}{l}\text { Slower (possibly five times slower } \\
\text { than the Pressure Subarea) }\end{array}$ \\
\hline
\end{tabular}




\section{Table 3: $\quad$ Pressure Subarea Estimated Seawater Intrusion Rates}

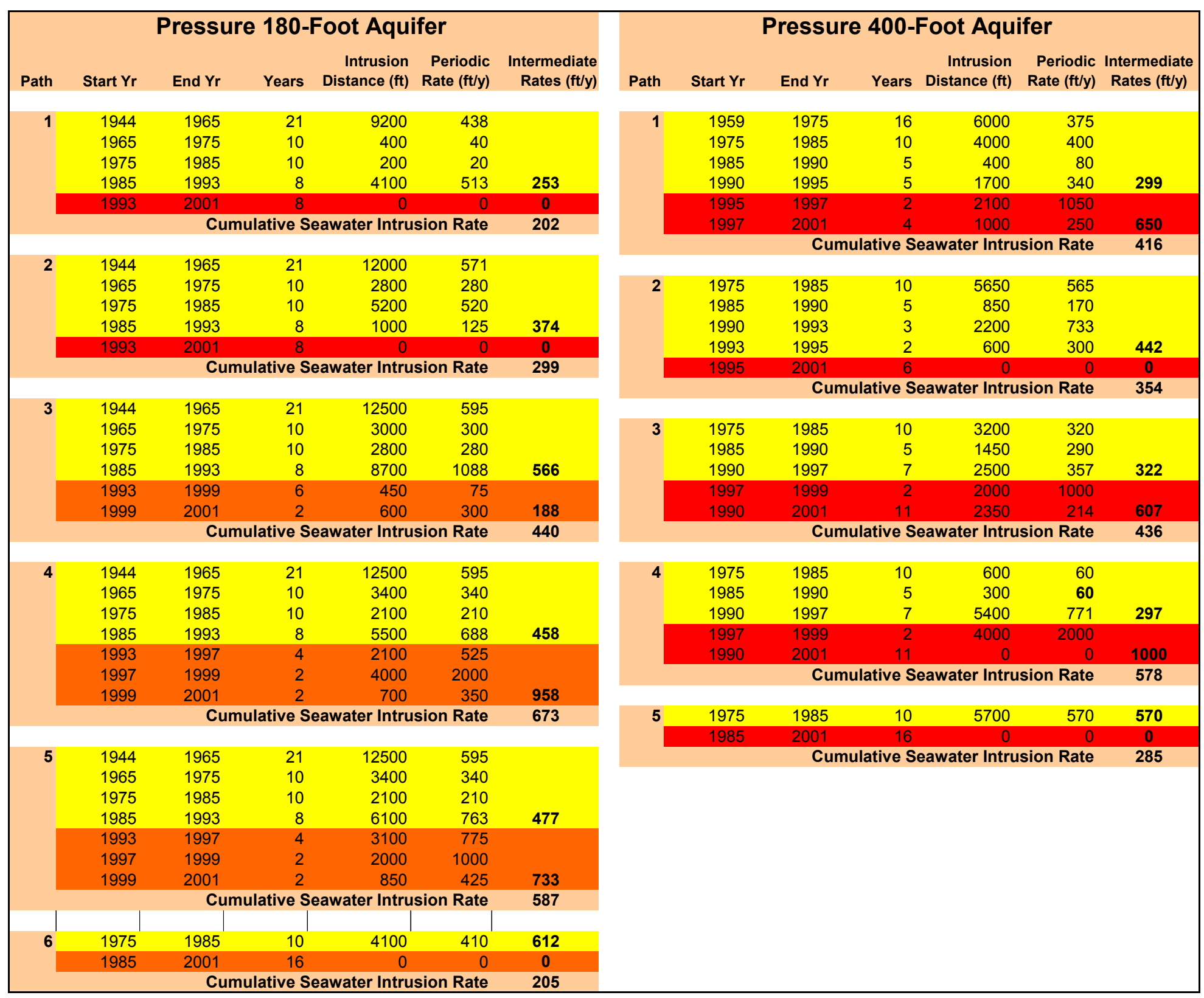

Final Report - Hydrostratigraphic Analysis of the Northern Salinas Valley 
Figures 


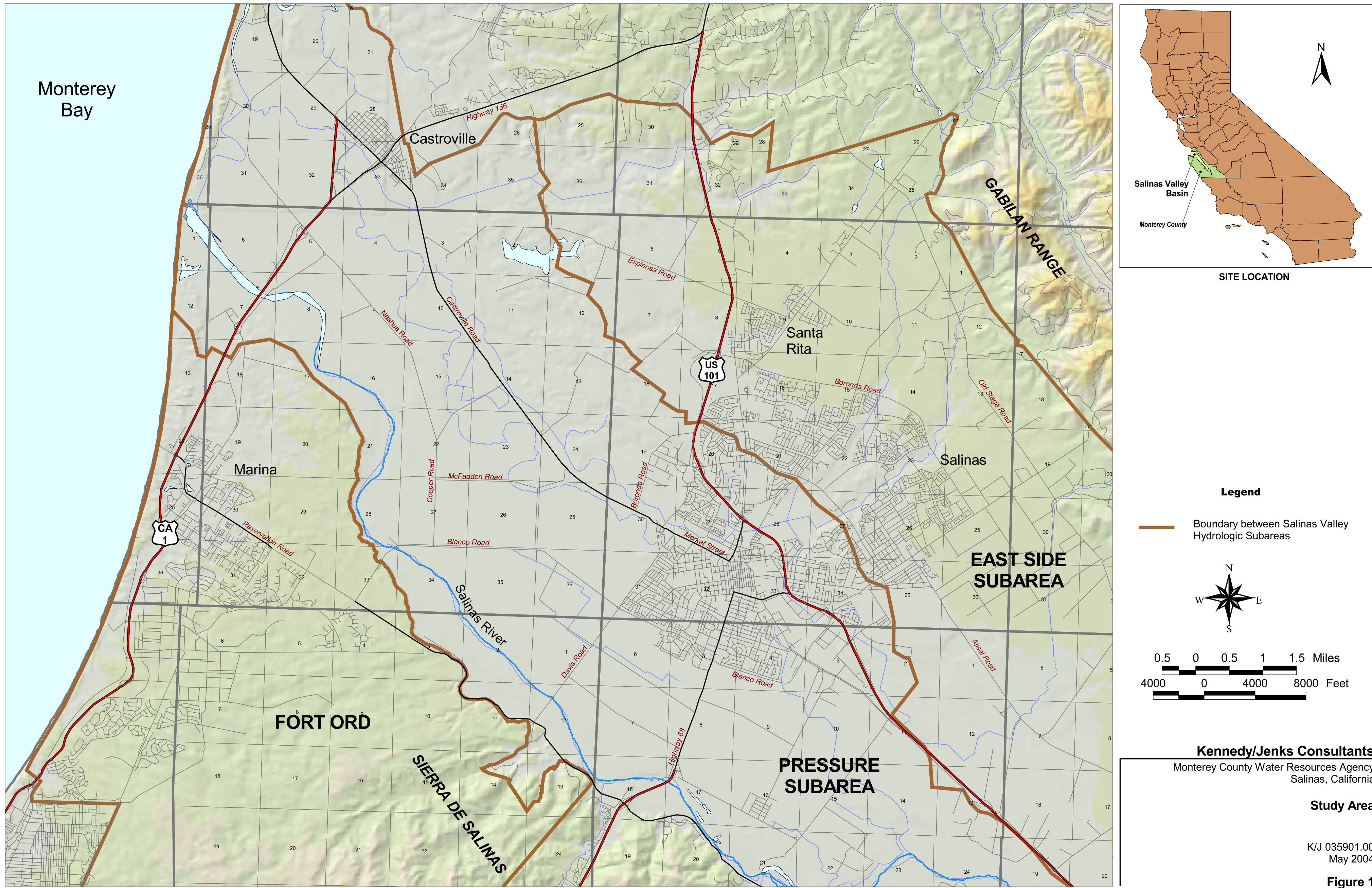





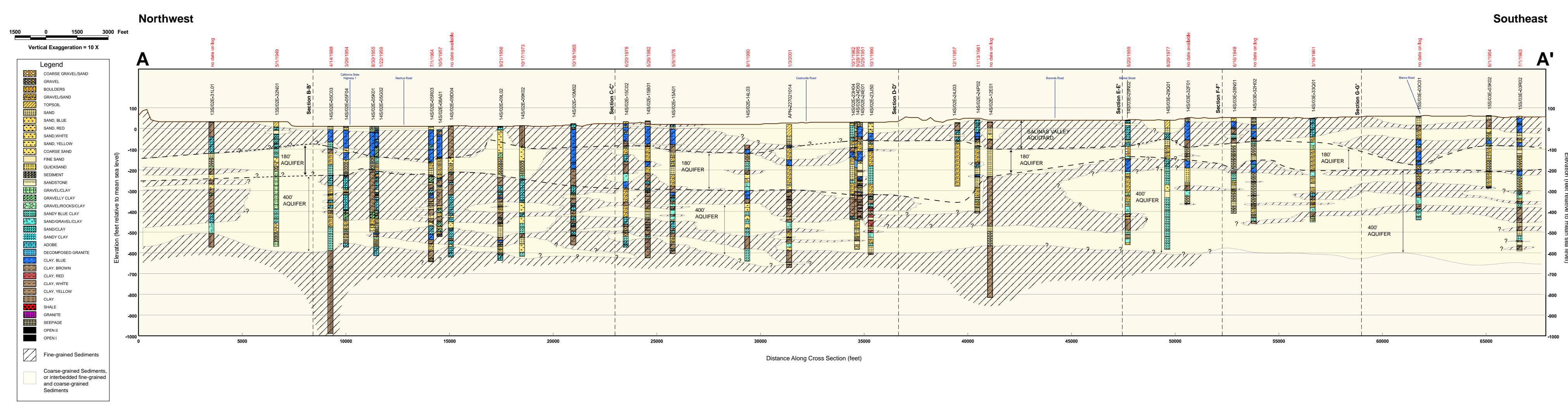

Kennedy/Jenks Consultants

Monterey County Water Resources Agency

Salinas, California

Cross-Section A-A'

K/J 035901.00

May 2004

Figure 3 


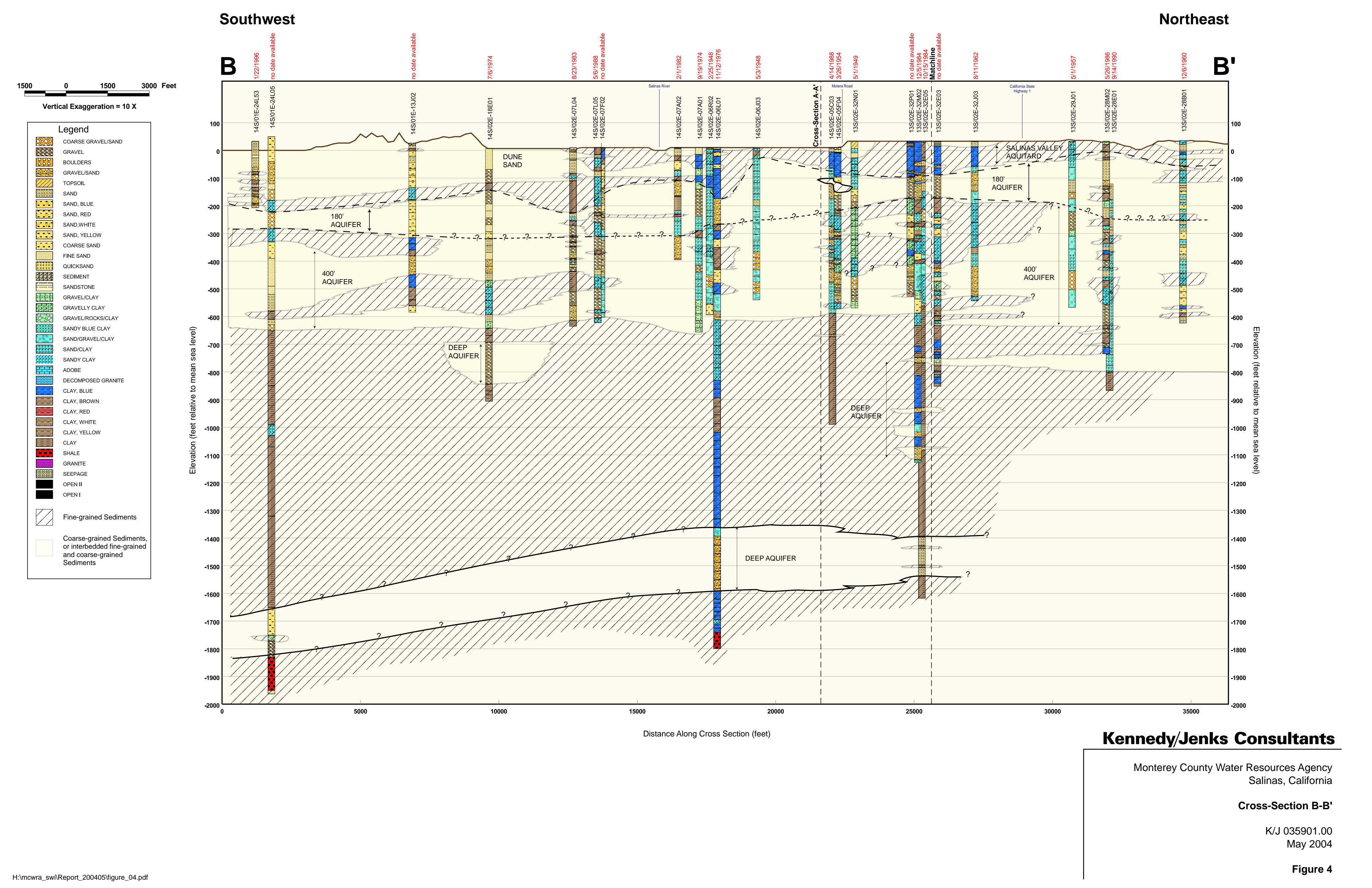



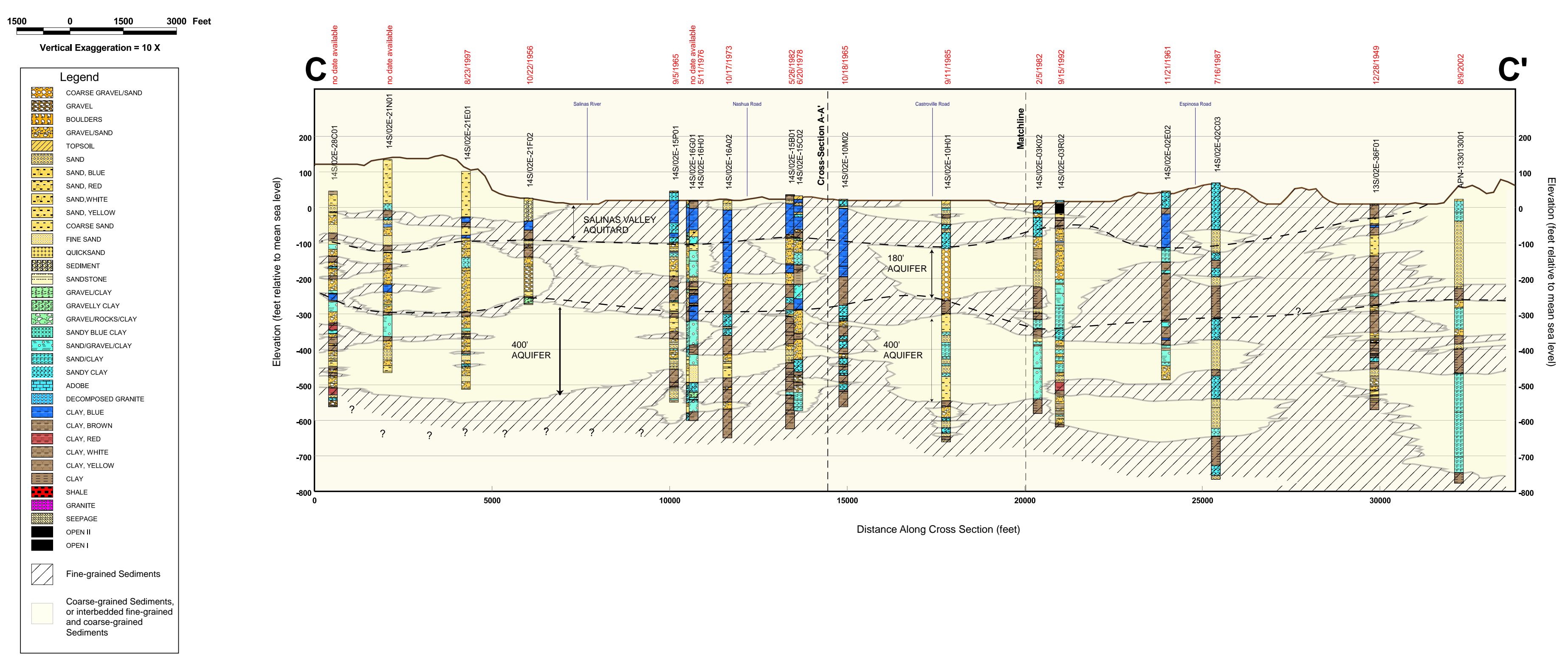

\section{Kennedy/Jenks Consultants}

Monterey County Water Resources Agency

Salinas, California

K/J 035901.00

May 2004

Figure 5 

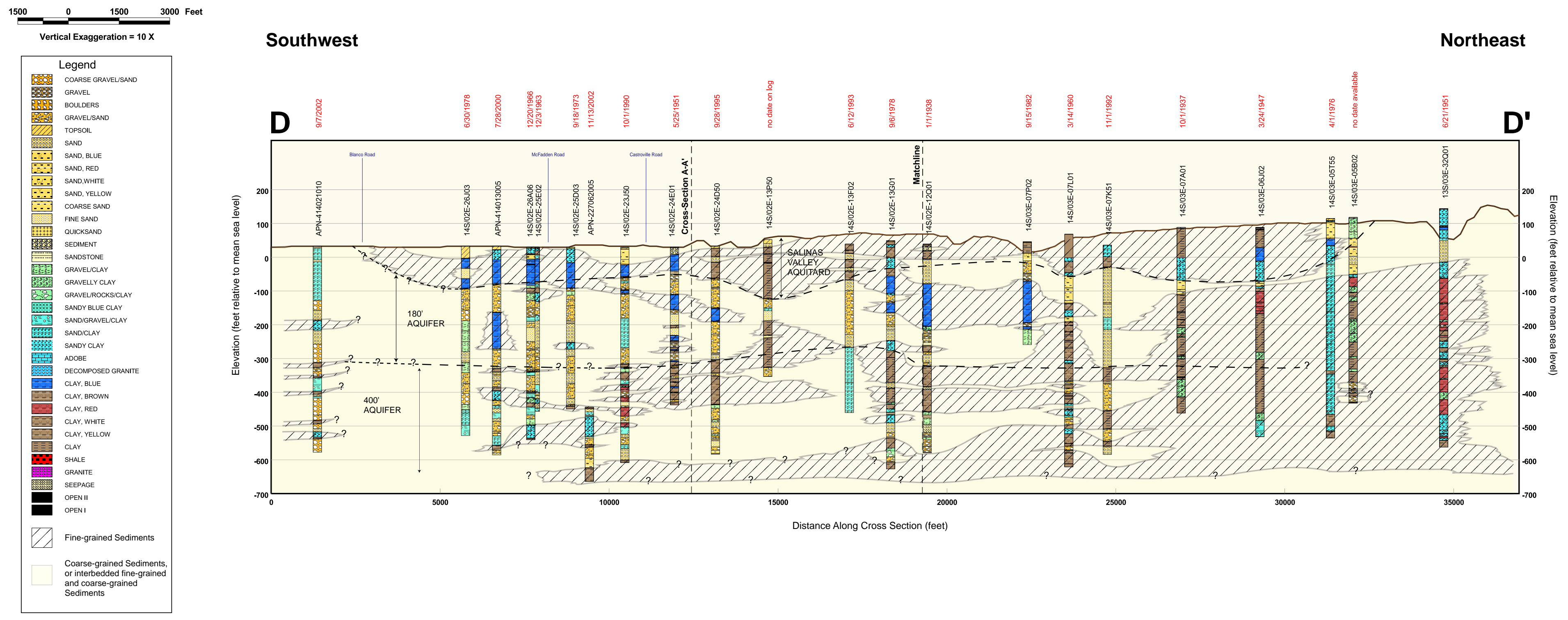

Kennedy/Jenks Consultants

Monterey County Water Resources Agency

Salinas, California

K/J 035901.00

May 2004

Figure 6 


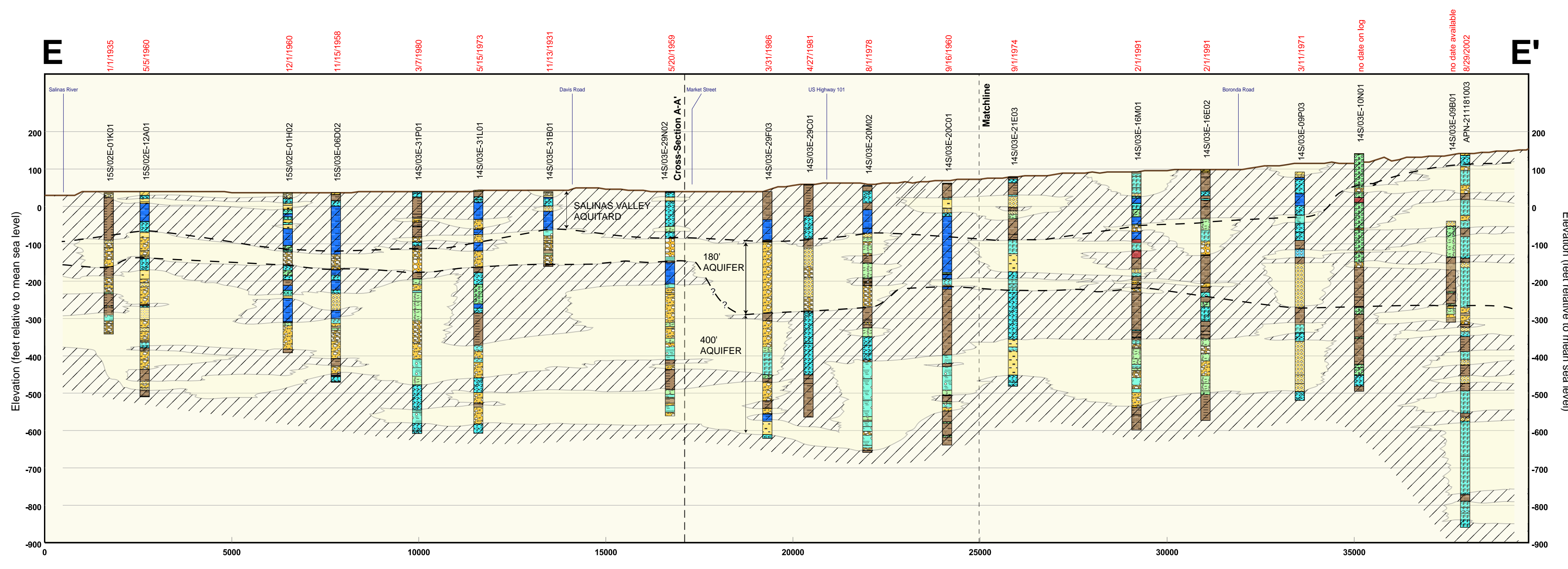




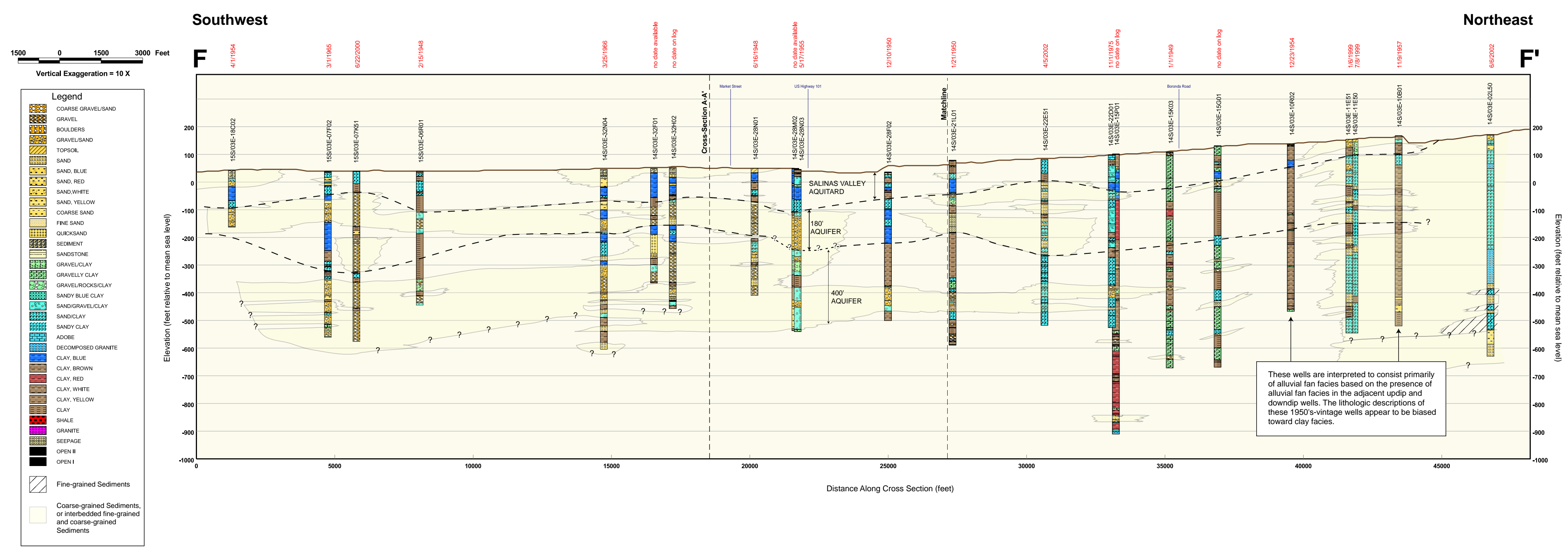

Kennedy/Jenks Consultants

Monterey County Water Resources Agency

Salinas, California

Cross-Section F-F'

K/J 035901.00

May 2004

Figure 8 


\begin{tabular}{|c|}
\hline Vertical Exaggeration $=10 \mathrm{X}$ \\
\hline Legend \\
\hline $\begin{array}{l}\text { COARES GRVUUSANO } \\
\text { GRAVEL }\end{array}$ \\
\hline 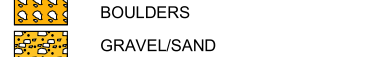 \\
\hline VIIA Trosson \\
\hline 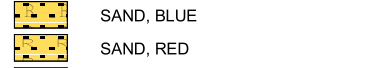 \\
\hline 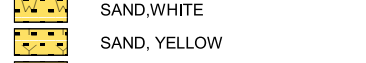 \\
\hline FNE SAND \\
\hline 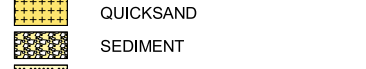 \\
\hline 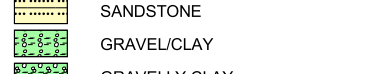 \\
\hline 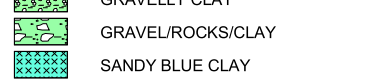 \\
\hline 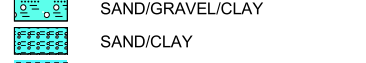 \\
\hline 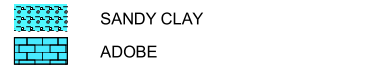 \\
\hline 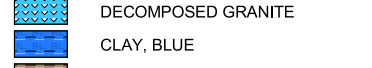 \\
\hline $\begin{array}{c}\text { Corar,Bown } \\
\text { CLYY,RED }\end{array}$ \\
\hline $\begin{array}{c}\text { ClaA, wHITE } \\
\text { CLAY, YELOW }\end{array}$ \\
\hline 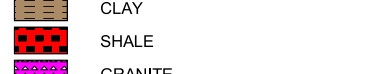 \\
\hline Defere \\
\hline ב \\
\hline$\square$ Fine-grained Sodiments \\
\hline $\begin{array}{l}\text { Coarse-grained Sediments } \\
\text { or interbedded fine-graned }\end{array}$ \\
\hline $\begin{array}{l}\text { and coarseg-g } \\
\text { Sedinents }\end{array}$ \\
\hline
\end{tabular}

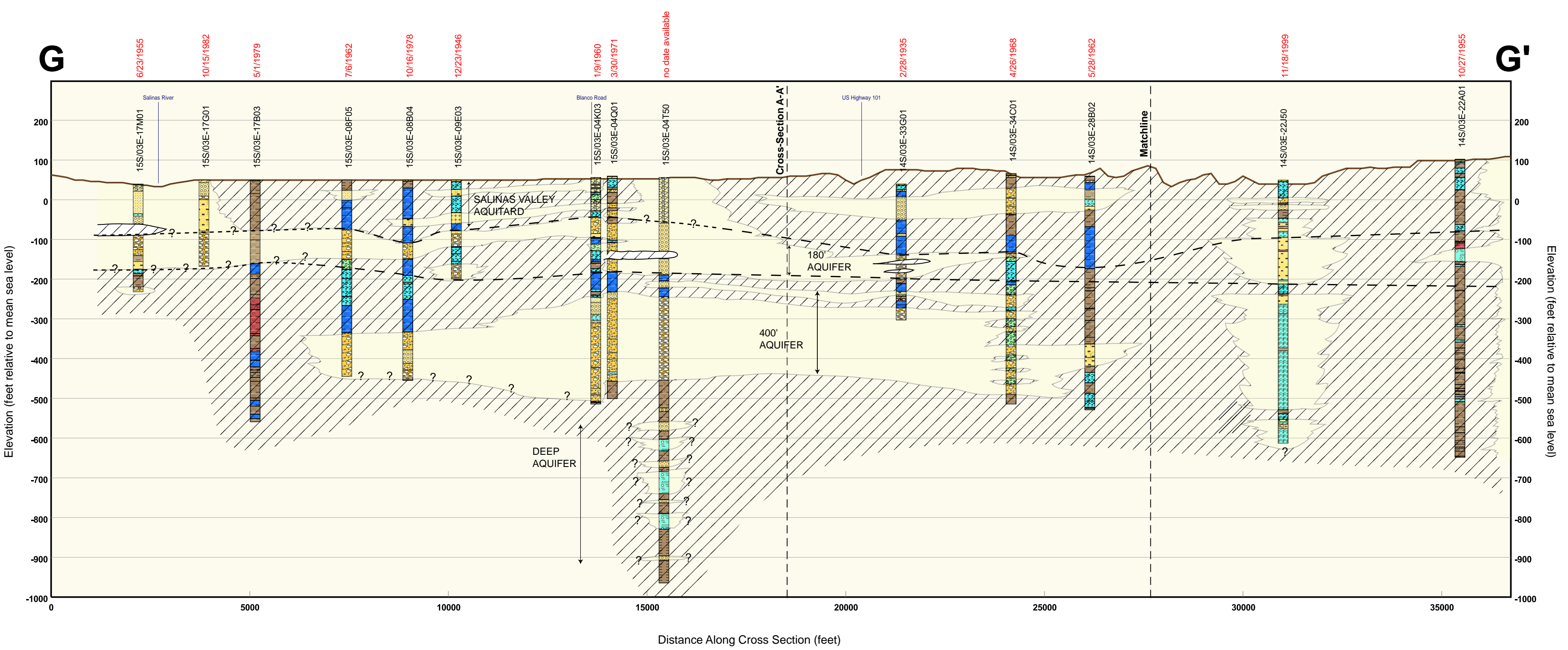

Kennedy/Jenks Consultants

Monterey County Water Resources Agency

Salinas, California

Cross-Section G-G'

K/J 035901.00 May 2004 



\section{GENERALIZED FLUVIAL AND ALLUVIAL FAN FACIES OF NORTHERN SALINAS VALLEY}

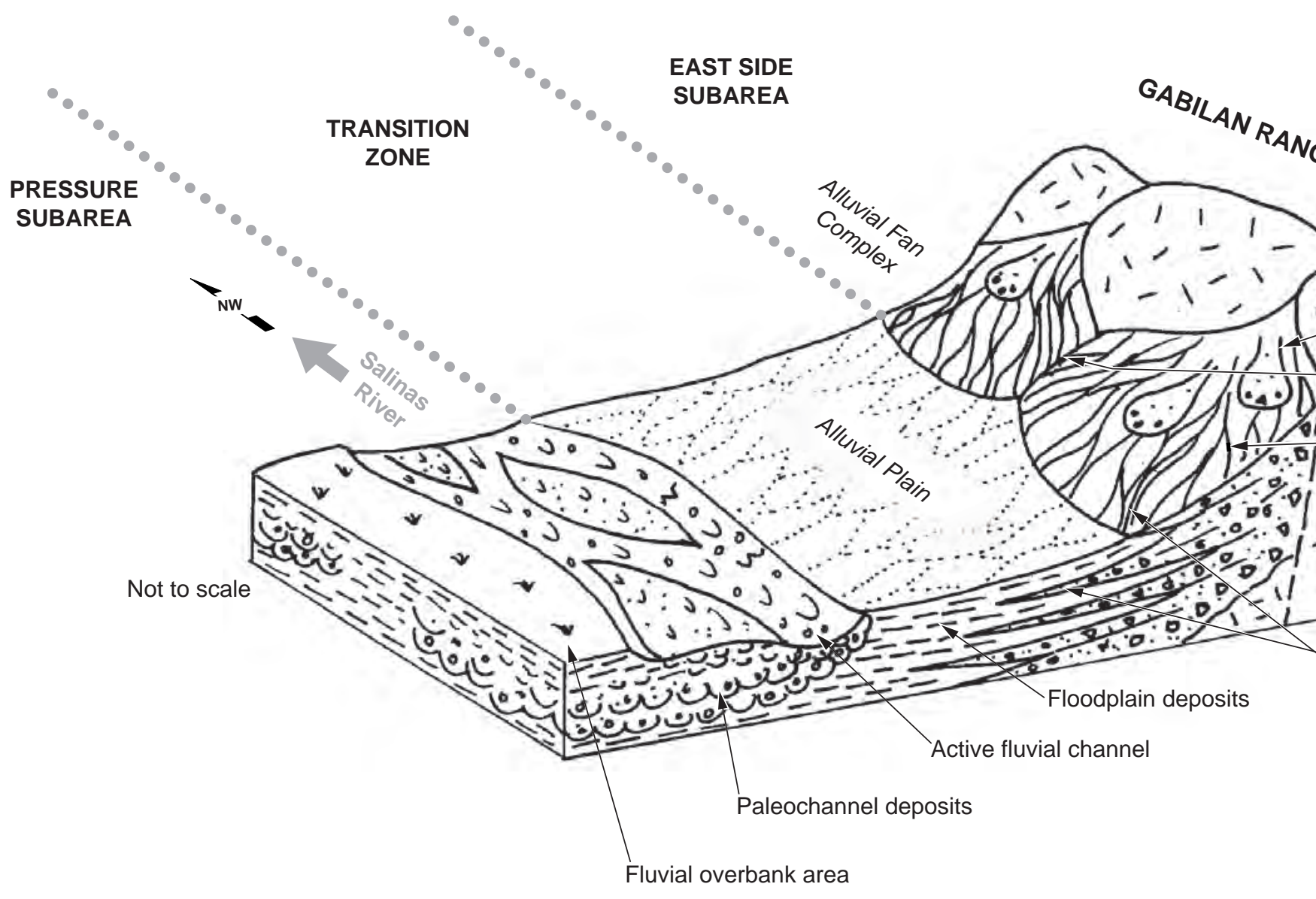

Note : See Section 5.1.2 for definitions of the transition zone and boundary between the Pressure and East Side Subareas.

Kennedy/Jenks Consultants

Monterey County Water Resources Agency Salinas, California

Generalized Fluvial and Alluvial Fan Facies of Northern Salinas Valley

K/J 035901.00 May 2004

Figure 11 


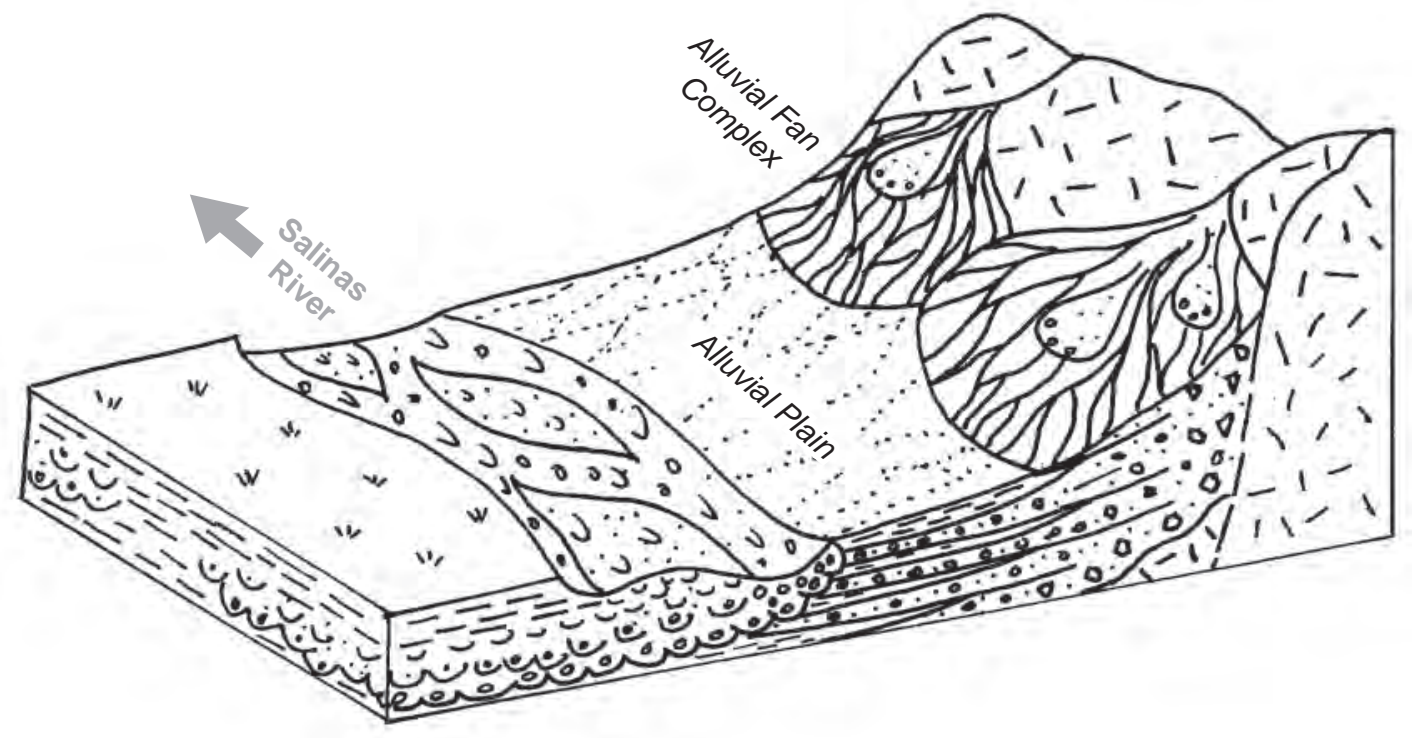

FACIES SCENARIO 1A

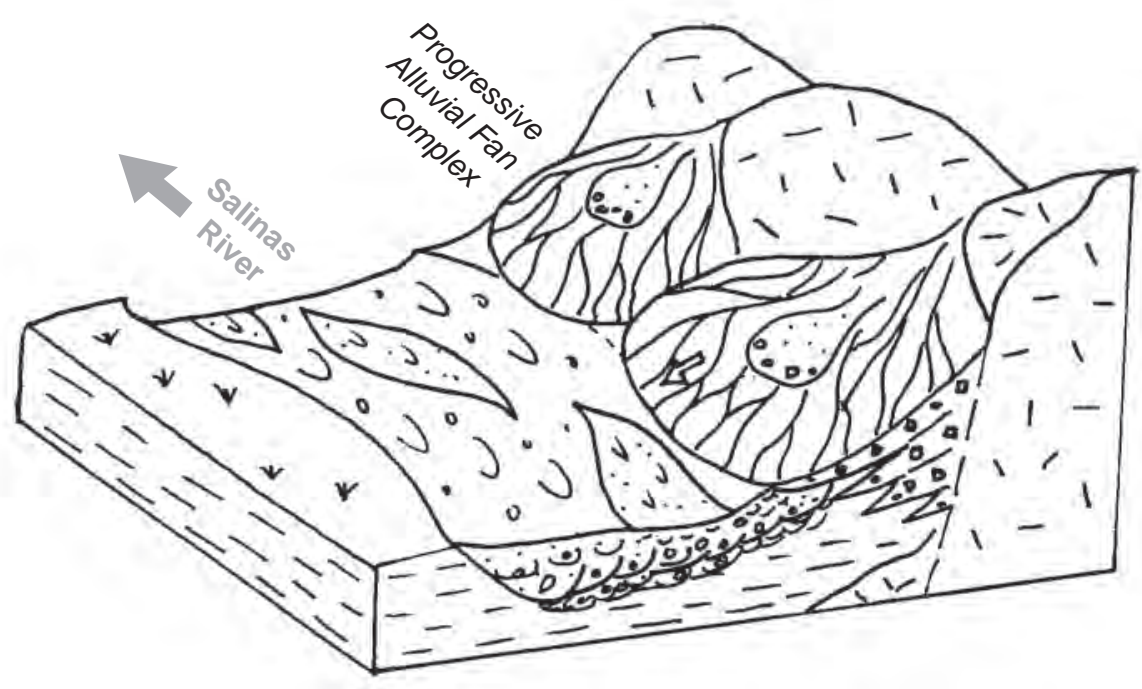

FACIES SCENARIO 1B

Facies Scenario 1: Permeable Facies of Pressure Subarea in Contact with Permeable Facies of East Side Subarea
Kennedy/Jenks Consultants

Monterey County Water Resources Agency Salinas, California

Facies Scenario 1

Note: Not to Scale
$\mathrm{K} / \mathrm{J} 035901.00$

May 2004

Figure 13 


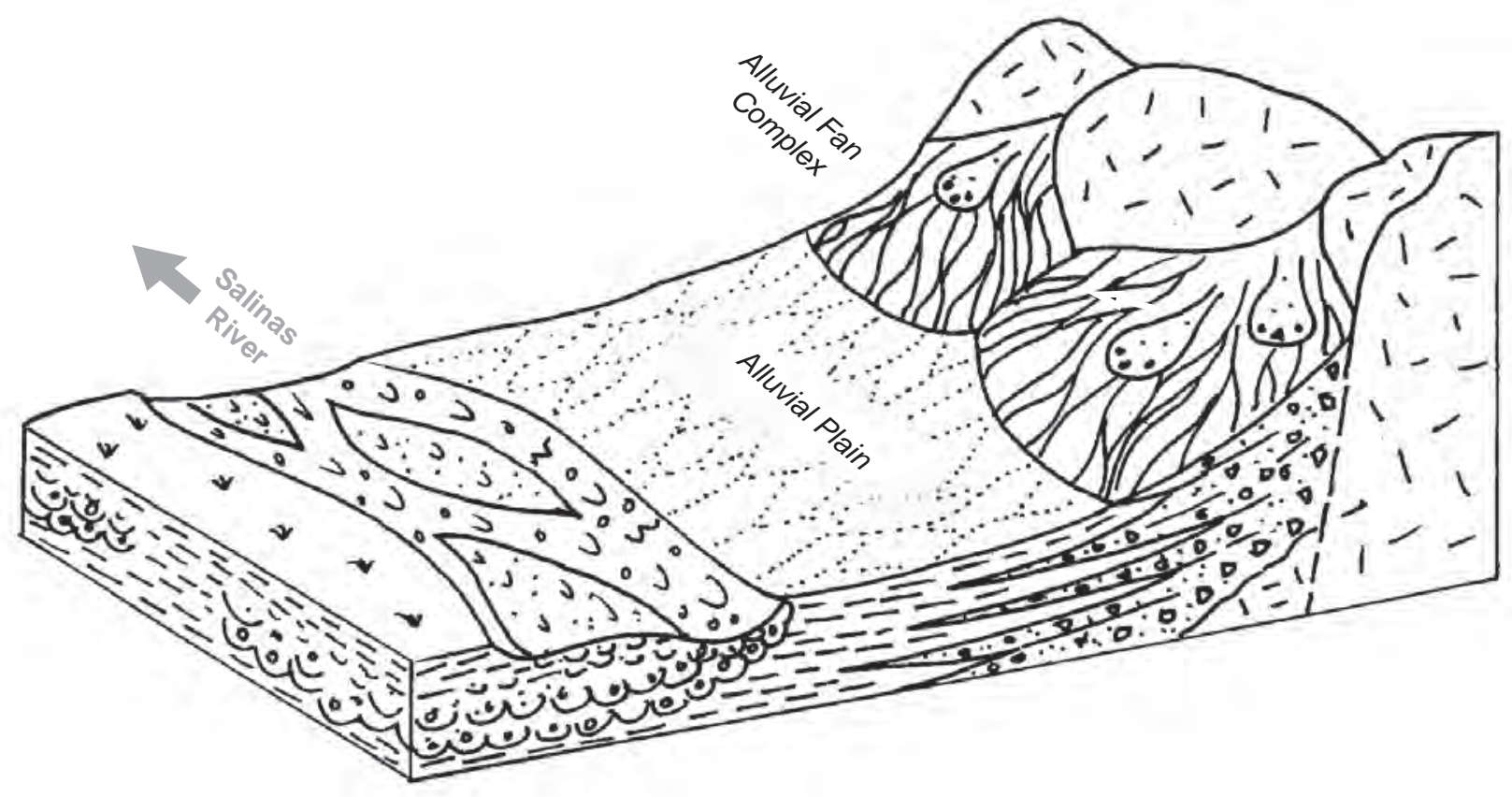

Facies Scenario 2 : Impermeable/Low Permeability Facies of Pressure Subarea in Contact with Impermeable/Low Permeability of East Side Subarea

Note: Not to Scale

Kennedy/Jenks Consultants

Monterey County Water Resources Agency Salinas, California

Facies Scenario 2

$\mathrm{K} / \mathrm{J} 035901.00$

May 2004

Figure 14 


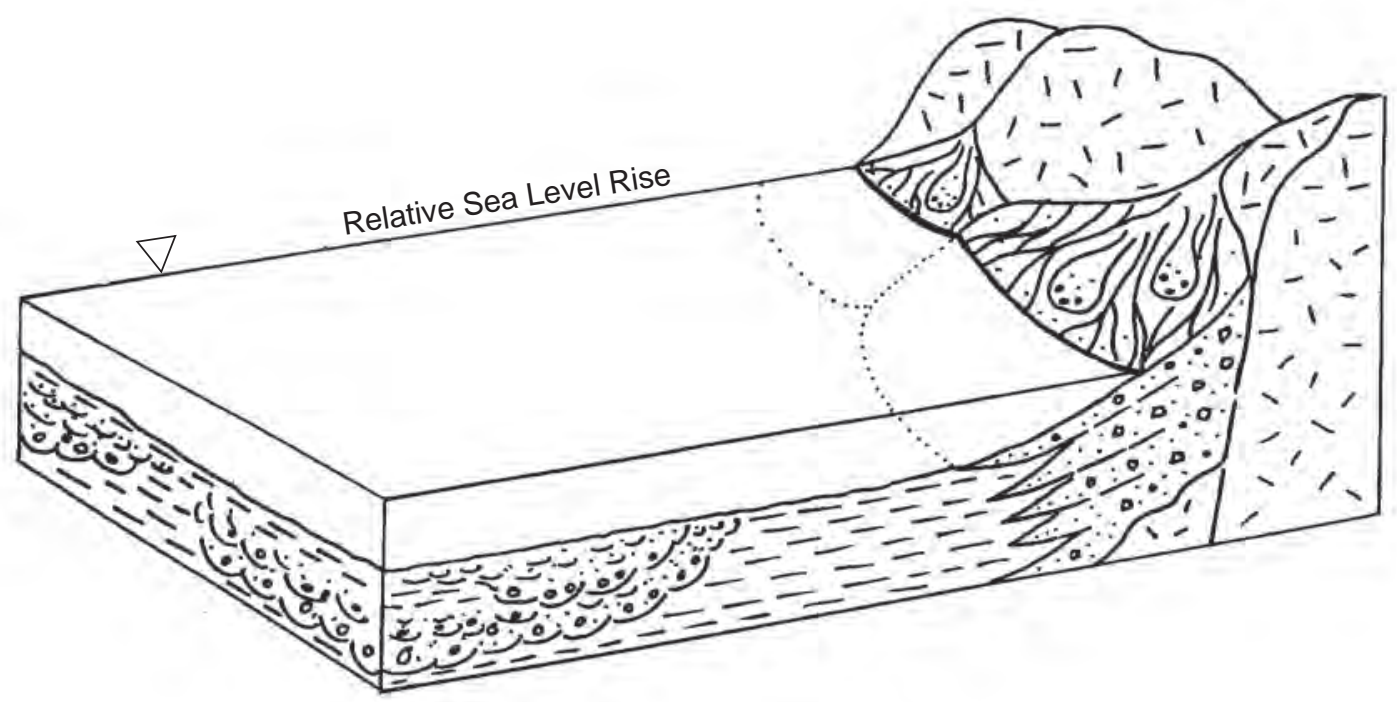

FACIES SCENARIO 3A

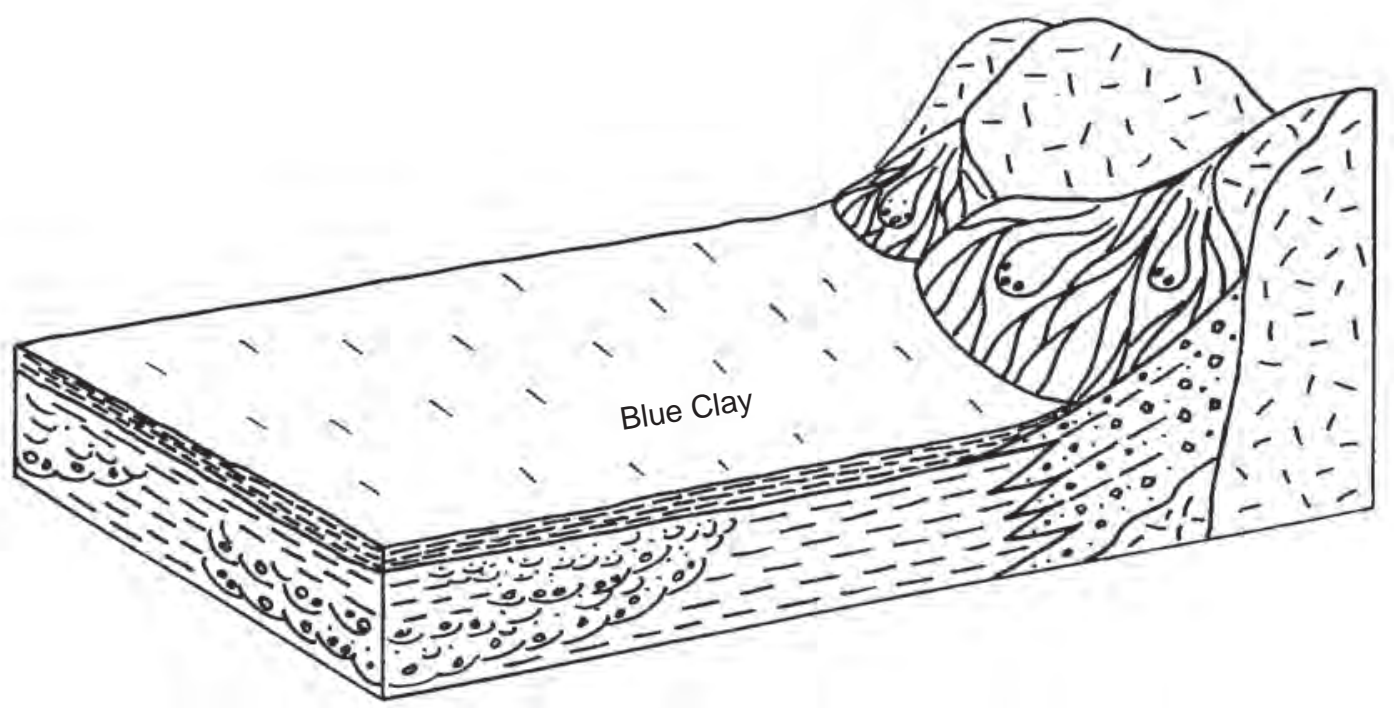

FACIES SCENARIO 3B

Facies Scenario 3 : Impermeable Blue Clay Facies of Pressure Subarea in Contact with Permeable Facies of East Side Subarea
Kennedy/Jenks Consultants

Monterey County Water Resources Agency Salinas, California

Facies Scenario 3

$\mathrm{K} / \mathrm{J} 035901.00$ May 2004

Figure 15 


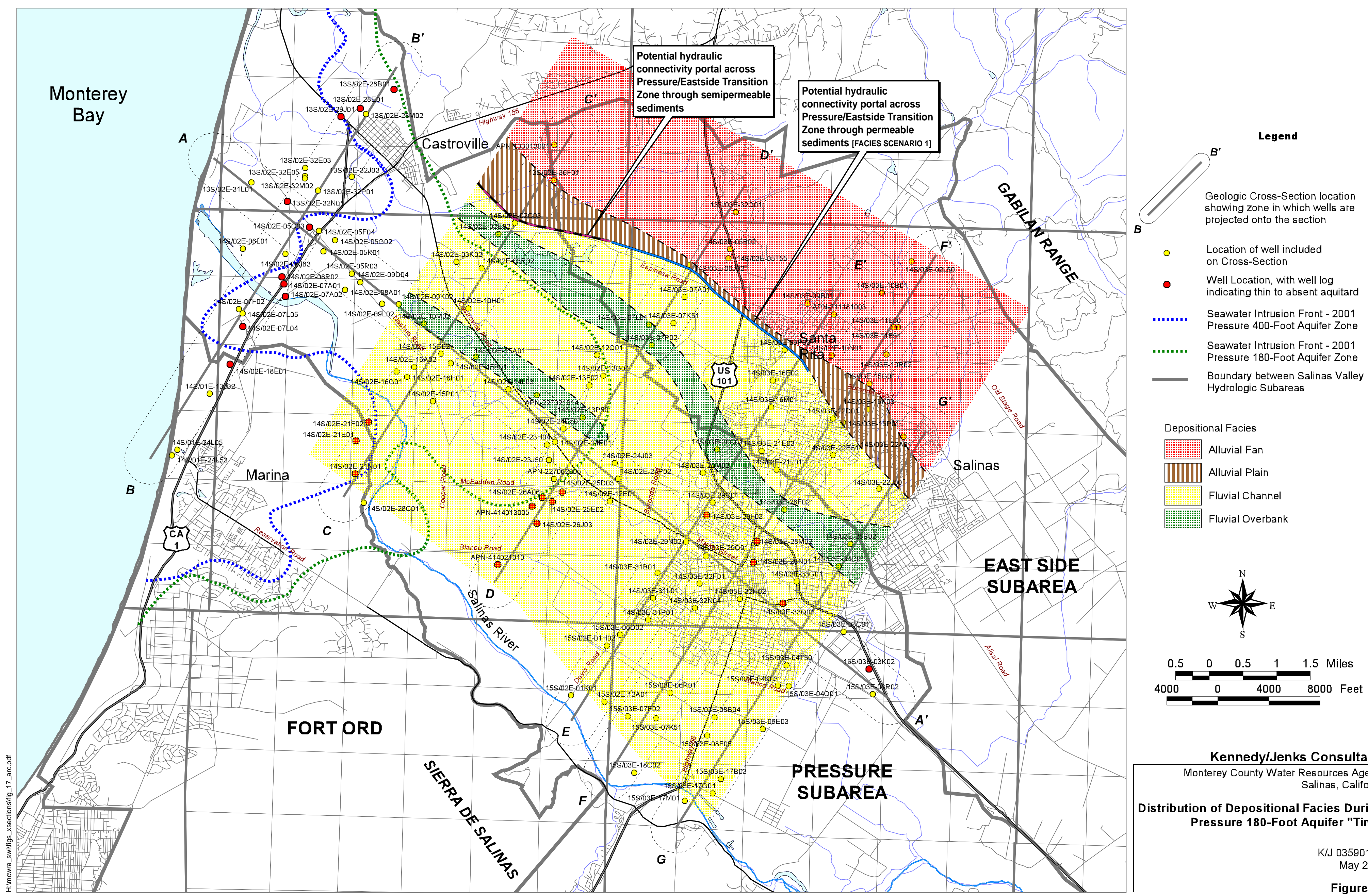

Depositional Facies

Alluvial Fan

|||||||| Alluvial Plain

Fluvial Channel

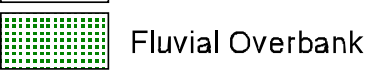

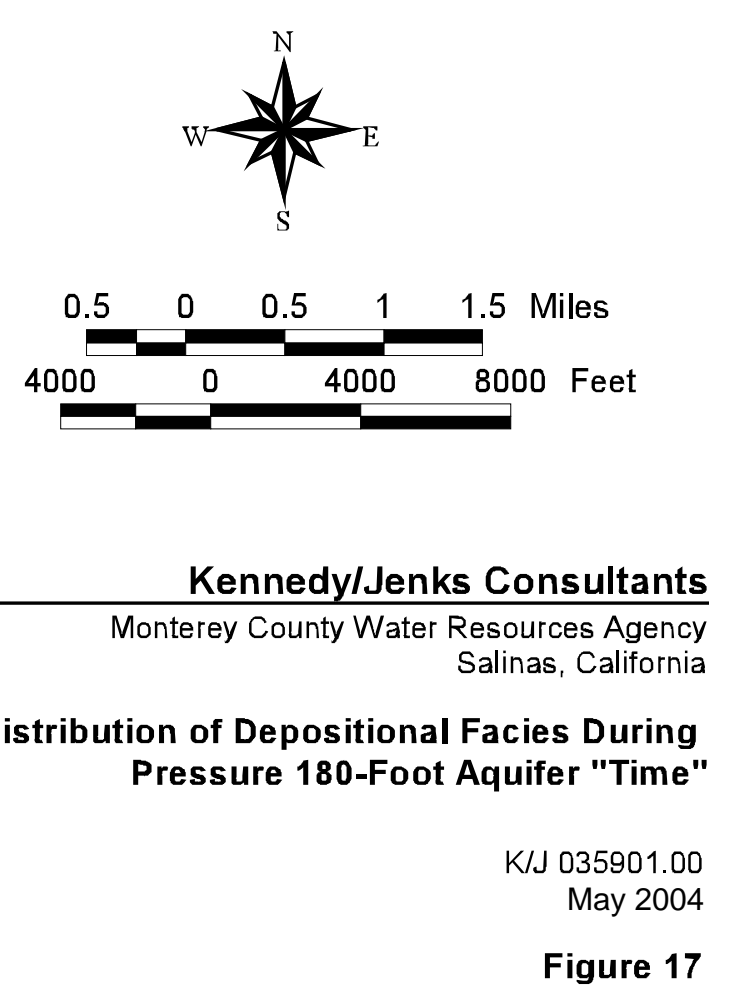





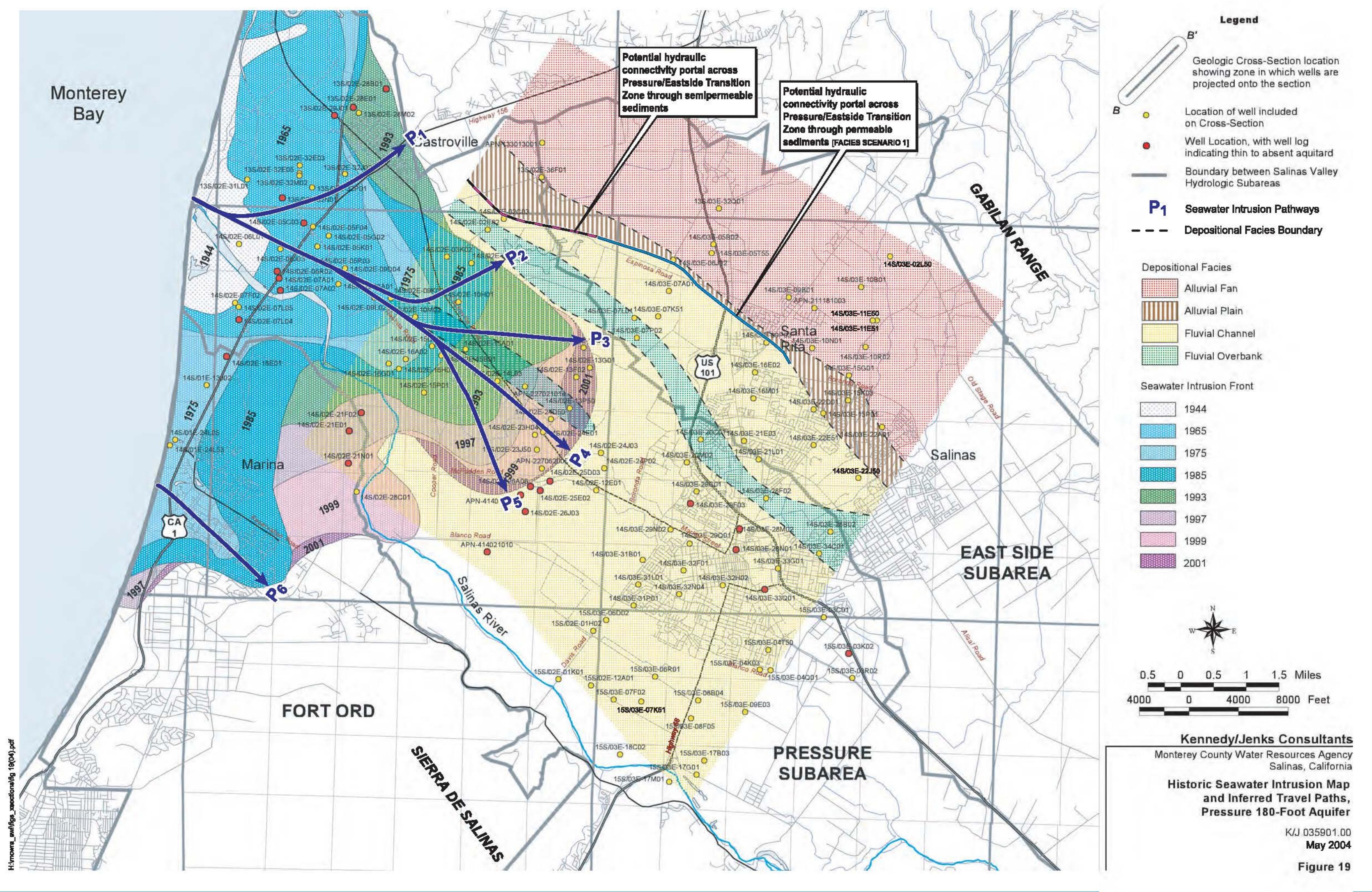




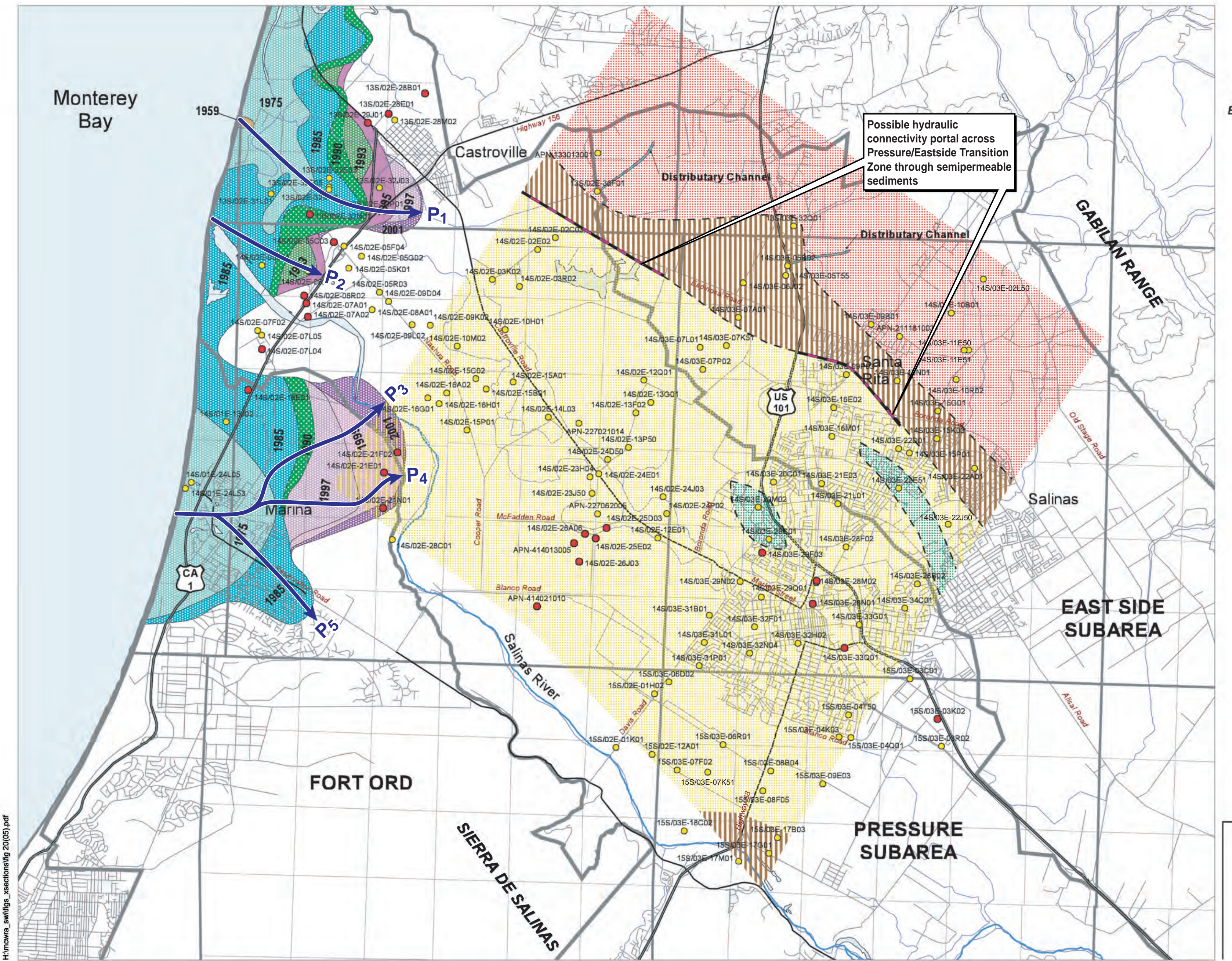

- Location of well included

Well Location, with well log
indicating thin to absent aquitard

Boundary between Salinas Valley

Hydrologic Subareas

P1 Seawater Intrusion Pathways

- Depositional Facies Boundary

\section{Depositional Facies}

Alluvial Fan

|III] II Alluvial Plain

Fluvial Channel

Fivinitin Fivial Overbank

Seawater Intrusion Front

$\square 1959$

W 1975

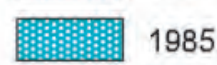

1990

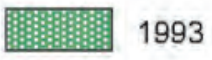

$\square 1995$

1997

1999

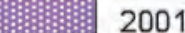
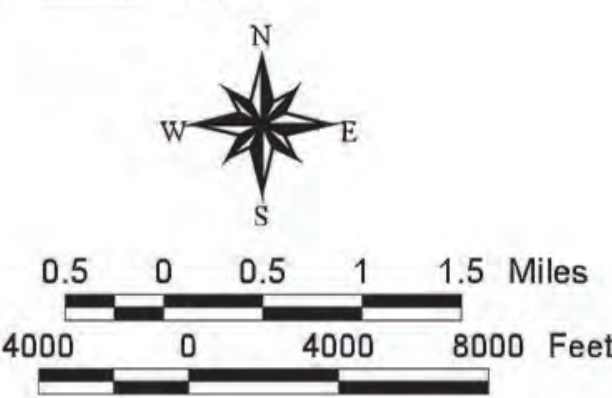

KennedylJenks Consultants Monterey County Water Resources Agency

Historic Seawater Intrusion Map and Inferred Travel Paths, Pressure 400-Foot Aquife

KIJ 035901.00
May 2004 Figure 20 
Appendix A Report Glossary 


\section{Appendix A: Report Glossary}

Acre

Aggradation

Alluvial

Alluvial Fan

Alluvial Plain

Alluviation

Alluvium

Angular

Anoxic

Aquiclude

Aquifer

Aquitard

Arkosic

Bed

Bedload
A measurement of area, equivalent to an area of 43,560 square feet.

The building up of the Earth's surface by deposition. A stream can aggrade by actively building up its channel or floodplain when it has more sediment load that it is capable of transporting.

A term used to describe material that has been deposited by a stream or running water.

An outspread, gently sloping mass of alluvium deposited where a stream flows from a canyon onto a valley floor.

A level or gently sloping land surface produced by extensive deposition of alluvium, usually adjacent to a river that periodically overflows its banks. The alluvial plain may be situated on a floodplain, delta, or an alluvial fan.

The deposition of alluvium along stream courses.

A general term for clay, silt, sand, gravel, or similar unconsolidated material deposited during comparatively recent geologic time by a stream or other body of running water.

Having sharp edges and corners; specifically said of a sedimentary particle showing little or no evidence of abrasion from water, wind, or collision with other particles.

Greatly reduced in oxygen concentration.

A saturated, but poorly permeable bed, formation, or group of formations that does not yield water freely to a well or spring. However, an aquiclude may transmit appreciable water to or from adjacent aquifers.

A formation, group of formations, or part of a formation that contains sufficient saturated permeable material to yield economical quantities of water to wells and springs.

A geologic formation, group of formations, or a part of a formation through which virtually no water moves.

Rich in feldspar (a commonly occurring rock-forming mineral that makes up $60 \%$ of the earth's crust), used to describe sandstone made of disintegrated granite.

The smallest unit of rock layering, commonly ranging in thickness from a centimeter to a meter or two and distinguishable from beds above and below.

The material on the bottom of a stream bed that is carried or rolled along by the force of the stream. This does not include smaller particles that are held in suspension in the water. 


\section{Kennedy/Jenks Consultants}

Brackish

Braided Stream

Channel

Channel-lag

Chert

Chloride

Clast

Clasts

Clay

Coalescing

Coarse-grained

Cone of

Depression

Confined Aquifer

Confining layers

Conformable

Conglomerate
Water with a salt and mineral content intermediate between that of normal sea water and that of normal fresh water.

A stream that divides into a tangled network of several small branching and reuniting shallow channels separated from each other by channel bars. Such a stream cannot carry all of its load, such as an overloaded stream flowing in a wide channel on a floodplain.

The deepest portion of a stream, bay, or straight.

The material within a stream bed that has enough mass that the force of the water does not move it.

A hard, dense microcrystalline (any crystals that may have formed are so small they cannot be seen by the unaided eye) sedimentary rock, consisting chiefly of quartz (a common rock-forming mineral composed of silica and oxygen).

A salt consisting of two elements, one of which is chlorine.

An individual constituent found within a rock or rock layer. It could be a grain or a fragment produced by the physical disintegration of a larger rock mass.

Grains or fragments of sedimentary rock.

A mineral particle having a diameter smaller than 1/256 millimeters $(\mathrm{mm})$, or an extremely fine-grained sediment or soft rock composed primarily of clay minerals.

Forming a continuous union.

When referring to sedimentary rock (in this report) it means the diameter of the average grain size larger than $2 \mathrm{~mm}$.

A depression in the ground water table or potentiometric surface that has the shape of an inverted cone and develops around a well from which water is being withdrawn. It defines the area of influence of a well.

A formation in which the ground water is isolated from the atmosphere at the point of discharge by impermeable geologic formations; confined ground water is generally subject to pressure greater than atmospheric.

A body of impermeable or distinctly less permeable material stratigraphically adjacent to one or more aquifers.

Strata characterized by an unbroken sequence in which the layers are formed one above the other in parallel order by uninterrupted deposition.

A coarse-grained sedimentary rock composed of fragments from pre-existing rocks, consisting of rounded rock fragments larger than $2 \mathrm{~mm}$ in diameter (granules, pebbles, cobbles, boulders) cemented together in a fine-grained matrix of sand or silt, with calcium carbonate, iron oxide, silica, or hardened clay acting as the cementing agent. 


\section{Kennedy/Jenks Consultants}

\begin{abstract}
Connate
Contamination

Contour

Cross-bedded

Water trapped in the void spaces of sedimentary rock at the time the rock was deposited.

The degradation of natural water quality as the result of man's activities. There is no implication of any specific limits, because the degree of permissible contamination depends upon the intended end use, or uses, of the water.

A line on a map that connects points of equal value.

Cross-bedding in sandstone is among the most common of all sedimentary structures. The cross-bedding structure consists of thin layers that cross over each other within a rock or rock layer. They typically consist of sand that has been deposited by wind or water. The layers create a pattern that lets geologists know the direction of the wind or water and which way was "up" during deposition.
\end{abstract}

Cross-Section

Debris Flow

Deposition

Depositional

Depositional

Environment

Detrital

Dip

Distal

Distributary Stream

Drainage Basin

Drawdown

Drilling Fluid

A diagram or drawing that shows the features transected by a vertical plane. A geologic cross-section shows the surface and subsurface geology in a vertical transect through the Earth; the cross-section line indicates the location of the vertical plane.

A moving mass of rock fragments, soil, and mud.

The laying-down of rock-forming material, such as by the mechanical settling of sediments from suspension in water.

Involving the laying-down of rock-forming material by any natural agent (such as wind or water).

The environmental setting (e.g., fluvial, estuarine, shallow marine, deep marine, lacustrine, deltaic, etc.) in which sediments are deposited.

Formed from loose rock and mineral material produced by mechanical means (being broken down the contact with other particles carried by wind or water).

The way the "steepness" of geologic features is defined. It is the angle that a stratum or planar feature makes with the horizontal, measured perpendicular to the strike (the level line across a sloping plane) and in the vertical plane.

A deposit formed at a considerable distance from where it was deposited.

A divergent stream flowing away from the main stream and not returning to it, such as in a delta or on an alluvial fan. (Antonym = tributary.)

A region surrounded by elevated land whose drainage converges to a single stream.

The distance between the static water level and the surface of the cone of depression.

A water- or air-based fluid used in the water well drilling operation to remove cuttings from the hole, to clean and cool the bit, to reduce friction between the drill string and the sides of the hole, and to seal the borehole. 


\title{
Kennedy/Jenks Consultants
}

\author{
Dune sand \\ A mound, ridge, or hill of wind-blown sand, either bare or covered with vegetation. \\ Eolian \\ Pertaining to the wind; said of erosion and deposition accomplished by the wind. \\ Estuarine \\ Of, pertaining to, or formed in a tidal mouth of a river valley where fresh water comes \\ into contact with sea water and where tidal effects are evident. \\ Estuarine Deposits \\ Sedimentary deposits laid down in the brackish water of an estuary, characterized by \\ fine-grained sediments (predominantly clay and silt) of marine and fluvial origin mixed \\ with decomposed terrestrial organic matter. \\ Estuary \\ A partially enclosed coastal body of water where the tide meets the current of a \\ stream. The seaward end of a river valley where fresh water comes into contact with \\ seawater and where tidal effects are evident. \\ Eustatic \\ Pertaining to global changes in sea level that affect all oceans. Eustatic changes \\ during the past few million years were caused by variations in the volume of \\ continental ice caps. \\ Facies \\ The characteristics of a rock unit, usually reflecting the conditions of its origin. The \\ overall aspect or set of characteristics of a rock, which reflects its particular \\ depositional environment and distinguishes it from adjacent facies within the same \\ rock unit. \\ Fauna \\ The entire animal population, living or fossil, of a given area, environment, formation, \\ or time span. \\ Fine-grained $\quad$ Rock or soil in which the particles have an average diameter less than 1/16 mm. \\ Floodplain \\ The relatively flat portion of a river valley adjacent to a river channel that becomes \\ covered with water when the river overflows its banks. It is built of alluvium carried by \\ the river during floods and deposited in the sluggish water beyond the influence of the \\ swiftest current. Floodplain deposits commonly comprise abundant silt and clay. \\ Fluvial Pertaining to rivers or produced by the action of a stream or river. \\ Foraminifer A single-celled organism which can sometimes be used to tell how old a rock is. \\ Foraminiferal A protozoan belonging to the subclass Sarcodina, order Foraminifera, with a test \\ (shell) that consists of secreted calcite or agglutinated particles. \\ Forebay \\ An area where water may percolate through the underlying soils to recharge ground \\ water supplies. \\ Formation A body of rock identified by lithic characteristics and stratigraphic position. \\ Friable $\quad$ A rock or mineral that is easily crumbled. \\ Geographic Looking at different aspects of regions or areas of the earth's surface.
}




\title{
Kennedy/Jenks Consultants
}

\author{
Geographical \\ Information System \\ (GIS) \\ A computer system used to capture, store, check, integrate, manipulate, analyze and \\ display data related to positions on the Earth's surface. Typically, GIS is used for \\ handling maps with multiple layers of information about a given area or region. \\ Geologic formation \\ A body of rock that consists dominantly of a certain rock type or combination of rock \\ types. \\ Ghyben-Herzberg \\ Principle \\ A ratio describing the static relation of fresh ground water and saline ground water in \\ coastal areas. For each foot of fresh water head above sea level, the salt water \\ surface is displaced to 40 feet below sea level, i.e., in a ratio of 1:40. \\ Glacio-eustatic \\ Worldwide changes in sea level caused by the melting or freezing of glaciers. \\ Granitic \\ Made of a plutonic rock (a rock that was formed from molten material at great depth \\ below the earth's surface). Granite consists of 10 to 50 percent quartz and 65 to 90 \\ percent feldspar (a very common rock-forming mineral that makes up sixty percent of \\ the earth's crust). \\ Gravel \\ Unconsolidated natural accumulation of rounded rock pieces, mostly of particles \\ larger than sand (greater than $2 \mathrm{~mm}$ in diameter). \\ Ground Water \\ Basin \\ A subsurface structure having the character of a basin with respect to the collection, \\ retention, and outflow of water. \\ Ground Water \\ Table \\ The surface between the zone of aeration (vadose zone) and the zone of saturation; \\ the surface of an unconfined aquifer. Also referred to as "water table." \\ Head \\ Energy contained in a water mass, produced by elevation, pressure, or velocity. \\ Holocene \\ An epoch of the Quaternary period, from the end of the Pleistocene (approximately \\ 10,000 years ago) to the present time. (Synonym = "Recent".) \\ Hydraulic \\ Moving of a fluid (especially water) under pressure. \\ Hydraulic \\ communication \\ Fluid flow between varying basins or hydraulic compartments or types (such as \\ between groundwater and surface water or between two different aquifers). \\ Hydraulic \\ Conductivity \\ Permeability coefficient; the rate of flow of water in gallons per day through a cross- \\ section of 1 square foot under a unit of hydraulic gradient. \\ Hydraulic gradient The difference in elevation of the surface of the groundwater at two (or more) points \\ divided by the distance of travel between the points. \\ Hydrogeologic Those factors that deal with subsurface waters and related geologic aspects of \\ surface waters. \\ Hydrogeology The science of subsurface waters and geologic aspects of surface water. \\ Hydrostatic The pressure exerted by the water at any given point in a body of water at rest. \\ pressure
}




\title{
Kennedy/Jenks Consultants
}

\begin{abstract}
Hydrostratigraphic Grouping of rock/sedimentary units based on the capacity of the rock, sediment, or soil to transmit water.

Hydrostratigraphy The identification of units of rock or soil layers below the earth's surface on the basis of hydraulic properties (aquifer/aquitards).

Igneous Rocks Rocks that solidified from molten or partly molten material, that is, from magma.

Incision

The process whereby a downward-eroding stream deepens its channel or produces a narrow, steep-walled valley. Incision can occur as a result of a eustatic or relative fall in sea level, which lowers the base level of a stream or river flowing to the ocean.

Interbedded When rock layers or beds are lying between or alternating with others layers or beds of different character.

Intercalated When layered material exists or is introduced between layers of a different character.

Interchannel The area between active fluvial channels. The interchannel area is part of the floodplain, and is dominated by fine-grained sedimentary deposits.

Interfinger

When a series of wedge-shaped layers are found within a material of a different character.

Inundation

Covered, as with a flood.

Ion

An electrically charged atom or group of atoms.

Isochlor

Line of equal concentration of chloride ions.

Lacustrine

Pertaining to, produced by, or formed in a lake.

Lenticular

Lithic

Resembling in shape the cross section of a lens (a shape that bulges in the middle and pinches out on either side).

Pertaining to or made of stone.

Lithofacies

Lithological characteristics of a formation. A mappable subdivision of a designated stratigraphic unit, distinguished from adjacent subdivisions on the basis of lithology, including all mineralogic, petrographic, and paleontologic characteristics that influence the appearance, composition, or texture of the rock.

Lithology Physical character or description of rocks, such as color, grain size, and mineral composition.

mg/l $\quad$ Milligrams per liter

Miocene An epoch of the early Tertiary period.

Mollusc An invertebrate belonging to the phylum Mollusca. Molluscs include gastropods (e.g., snails), pelecypods (e.g., clams), and cephalopods (e.g., squids). (Also referred to as mollusks.)
\end{abstract}




\title{
Kennedy/Jenks Consultants
}

\begin{abstract}
Morphology The shape of the earth's surface (i.e. mountains and stream beds are part of the morphology).

MSL

Mudstone

Onlap

Mean sea level; the average height of the sea between high and low tides.

A blocky fine-grained sedimentary rock like shale but it does not have the layered character of shale.

A unique rock layer that overlaps a different rock layer and is characterized by the regular and progressive pinching out, toward the margins or shores of a depositional basin, of the sedimentary units within a conformable sequence of rocks. The boundary of each unit is transgressed by the next overlying unit and each unit in turn terminates farther from the point of reference. This is created when a depositional basin has an elevation gain at the end farthest from the source of deposition.

Therefore the shape of the bottom of the deposition is created by the existing shape of the basin.
\end{abstract}

Outcrop

Outwash

Overbank deposit

Overdraft

Oxidizes

Perched

groundwater

Percolate

Permeability

Permeability

Piezometric

Surface

Pleistocene

Pliocene

Porcelaneous chert
The part of a geologic formation or structure that appears at the surface of the earth.

Sand and gravel deposited by melt-water streams from an active glacier.

Silt and clay deposited from suspension on a flood plain by floodwaters that flow over the banks of the stream channel.

Withdrawal of ground water in excess of replenishment.

Causes the process of combining with oxygen.

Unconfined groundwater separated from the underlying main body of groundwater by a restrictive layer (typically clay).

The act of water seeping or filtering through the soil without a definite channel.

The capacity for transmitting a fluid. This is a measurement of the relative ease in which fluid will flow through a given material.

The property or capacity of a porous rock, sediment, or soil for transmitting a fluid; it is a measure of the relative ease of fluid flow under unequal pressure.

An imaginary surface representing the total head of ground water and defined by the level to which water will rise in a well. The water table is a particular piezometric surface. (Synonym = potentiometric surface.)

An epoch of the Quaternary period that began 2-3 million years ago and lasted until the start of the Holocene approximately 10,000 years ago.

The final epoch of the Tertiary period.

A hard, opaque chert (a hard microcrystalline rock containing mostly quartz) having a smooth fracture surface and a typically china-white appearance resembling chinaware or glazed porcelain. 


\section{Kennedy/Jenks Consultants}

Porcelaneous

Chert

Porosity

ppm

Prograde

Provenance

Proximal

Quaternary

Recharge

Recharge

Regression

RWQCB

Sand

Sandstone

Sea Level

Seawater Intrusion

Sediment

Sedimentary

Sedimentary Rock

Shale
Hard, opaque chert having a smooth surface and china-white appearance.

The percentage of the bulk volume of a rock or soil that is occupied by interstices, whether isolated or connected.

Parts per million.

The building outward or forward of a succession of sediment (or delta, or alluvial fan, or shoreline) by deposition and accumulation of sediment.

A place of origin, specifically the area from which the constituent materials of a sedimentary rock or facies are derived.

Said of a deposit formed close to were the constituents of that deposition have derived.

A period of geologic time that began 2 to 3 million years ago and extends to the present.

Processes by which there is an addition of water to the aquifer.

The addition of water to the zone of saturation; also, the amount of water added.

The retreat of the sea from land areas. (Antonym = transgression.)

Regional Water Quality Control Board

A detrital particle smaller than a granule and larger than a silt grain, having a diameter in the range of $1 / 16$ to $2 \mathrm{~mm}$.

A sedimentary rock composed of abundant rounded or angular fragments of sand set in a fine-grained matrix (silt or clay) and more or less firmly united by a cementing material.

A popular synonym for mean sea level.

When seawater replaces fresher water within an aquifer.

Solid fragmental material (e.g., gravel, sand, silt, clay, etc.) that originates from weathering of rocks and is transported or deposited by air, water, or ice.

Describes a rock or layer of rock that was formed by the deposition of particles that become cemented together.

A layered rock resulting from the consolidation of sediment.

A fine-grained sedimentary rock, formed by the consolidation of clay, silt, or mud. It is characterized by finely laminated structure and is sufficiently indurated so that it will not fall apart on wetting. 


\section{Kennedy/Jenks Consultants}

Shale

Siliceous Shale

Silt

Siltstone

Static Water Level

Strata

Stratigraphy

Suboxic

Terrane

Tertiary

Total Dissolved

Solids (TDS)

Transgression

Tributary

Unconfined Aquifer

Unconfined

groundwater

USGS

Water Table

Watershed

Well Yield
Fine-grained sedimentary rock with thin layers. It is formed by the compaction of clay, silt, or mud.

A hard, fine-grained sedimentary rock with as much as $85 \%$ silica.

A particle finer than fine sand and coarser than clay.

A rock made of silt having the texture and composition of shale but lacking its fine layering.

The level of water in a well that is not being affected by withdrawal of ground water.

Layers of sedimentary rock.

The study of rock strata, especially of their distribution, deposition, and age.

Simultaneously low in oxygen and low in sulfide.

Rock or group of rocks and the area in which they crop out.

The period of geologic time covering the span of time between 65 million years ago and 2 million years ago.

A term that expresses the quantity of dissolved material in a sample of water.

The spread of the sea over land areas; also known as a marine transgression. A transgression can occur from a rise in eustatic sea level or a relative rise in sea level (e.g., a rise in sea level caused by the subsidence of land). (Antonym = regression.)

A stream that feeds, joins, or flows into a larger stream or lake. (Antonym $=$ distributary.)

An aquifer where the water table is exposed to the atmosphere through openings in the overlying materials.

Groundwater that has a free water table, meaning it is not confined under pressure beneath relatively impermeable strata.

United States Geological Survey

The surface between the zone of aeration (vadose zone) and the zone of saturation (ground water). That surface of a body of unconfined ground water at which the pressure is equal to that of the atmosphere. Also referred to as "ground water table."

A drainage basin.

The volume of water discharge from a well in gallons per minute or cubic meters per day. 
Appendix B

List of References Reviewed 


\section{Appendix B: List of References Reviewed}

Author

\begin{tabular}{lc}
\hline Anderson-Nichols/West & November 1984 \\
\hline Anderson-Nichols/West & August 1985 \\
\hline Anderson-Nichols/West & October 1985 \\
\hline Anonymous & 1909 \\
\hline Anonymous & 8 February 1949
\end{tabular}

Ares, Gene

Bond, L.D.

Boyle Engineering Corp.

Brown, Dick

Bunte Jr., Loran

Burns, Tom

Cleath and Associates

Conkling, Harold

Department of Water Resources

\section{Department of Water Resources}

Department of Water Resources

Department of Water Resources

Dupre,

\begin{tabular}{lc}
\hline Earthware & February 1992 \\
\hline Earthware & February 1992 \\
\hline Earthware & Unk. \\
\hline Earthware & Unk. \\
\hline Earthware & Unk.
\end{tabular}

EDAW August 1994

Fugro West, Inc.
Unk.

December 1987

6 May 1986

16 September 1959

June 1976

March 1991

1933

June 1970

July 1973 1946

July 1981

1990
October 1994
Title

Salinas River Study Phase I Report River Morphology and Behavior

Salinas Valley water Appropriation Study

Salinas River Study Phase II Report River Management Irrigation Edition Salinas Valley Rustler

Groundwater in California with Particular Reference to Salinas Valley

A Study and Report of the Possible Long-term Effects of Sodium on the Castroville Area Soils when Irrigated with Water from the 900 Foot Aquifer Pumped from Monterey County's Deep Well

The Role of Leakage in the Sea Water Intrusion of a Confined Coastal Aquifer.

Salinas Valley Ground Water Model Alternative Analysis

Geologic Study of 13S/2E and 14S/2E of Salinas Valley Draft Report

Summary of Reports on Water Supply and Development of Salinas Basin

Causes, Rates and Effects of Seawater Intrusion in the Lower Salinas Valley, Monterey County, California. Senior Thesis Hydrogeologic Investigation Salinas Valley Dispersed Well System Area

Report on Salinas Basin Preliminary Investigation

Sea-Water Intrusion, Lower Salinas Valley Progress Report 1968-1969

Sea Water Intrusion, Lower Salinas Valley

Bulletin 52 Salinas Basin Investigation

Sea Water Intrusion Salinas and Pajaro Rivers

Quaternary Geology of the Monterey Bay Region, California Lithologic logs from Geobase Vol. I Lithologic logs from Geobase Vol. II

Borehole Log Templates Getting Started with Geobase Geobase v. 7.01

Salinas River Basin Management Plan Alternatives Analysis Salinas River Basin Management Plan Hydrogeologic Assessment Report 


\section{Kennedy/Jenks Consultants}

\begin{tabular}{|c|c|c|}
\hline Author & Date & Title \\
\hline Fugro West, Inc. & August 1995 & $\begin{array}{l}\text { Salinas River Basin Management Plan Salinas Valley } \\
\text { Geohydrologic Study }\end{array}$ \\
\hline Grasty, James W & June 1988 & $\begin{array}{l}\text { A Gravity and Magnetic Study of the Armstrong Ranch } \\
\text { Area, Monterey County, California }\end{array}$ \\
\hline Greene, H. Gary & 1970 & $\begin{array}{l}\text { Geology of Southern Monterey Bay and its Relationship } \\
\text { to the Ground Water Basin and Salt Water Intrusion }\end{array}$ \\
\hline Greene, H. Gary & 1977 & Geology of the Monterey Bay Region \\
\hline Hall, Phillip & May 1992 & $\begin{array}{l}\text { Selected Geologic Cross Sections in the Salinas Valley } \\
\text { using Geobase }\end{array}$ \\
\hline Hamlin, Homer & 1904 & Water Resources of the Salinas Valley, California \\
\hline $\begin{array}{l}\text { Hanson, R.T., Everett, R.H., } \\
\text { Newhouse, M.W., Crawford, S.M., } \\
\text { Pimentel, I.S. }\end{array}$ & 2 April 2001 & $\begin{array}{l}\text { Preliminary Draft - Geohydrology of the Deep } \\
\text { Monitoring Well at Marina, Monterey County, California } \\
\text { (U.S. Geological Survey Water-Resources } \\
\text { Investigations Report 01-xxxx) }\end{array}$ \\
\hline Harding ESE & 12 April 2001 & $\begin{array}{l}\text { Final Report Hydrogeologic Investigation of the Salinas } \\
\text { Valley Basin in the Vicinity of Fort Ord and Marina } \\
\text { Salinas Valley, California }\end{array}$ \\
\hline Heard, J.E. & December 1992 & $\begin{array}{l}\text { Hydrogeology of High-Salinity Groundwater in the } \\
\text { "180-foot" Pressure Aquifer, southwest Salinas, } \\
\text { Monterey County, California Master's Thesis }\end{array}$ \\
\hline $\begin{array}{l}\text { John Mann, Ph.D., Cleath and } \\
\text { Associates }\end{array}$ & 1 October 1991 & $\begin{array}{l}\text { Well Selection Studies Castroville Area Sea Water } \\
\text { Intrusion Project }\end{array}$ \\
\hline Johnson, Michael & July 1983 & $\begin{array}{l}\text { Ground Water in North Monterey County, California, } \\
1980 \text { (U.S. Geological Survey Water Resources } \\
\text { Investigation Report 83-4023) }\end{array}$ \\
\hline Kenneth D. Schmidt & March 1985 & Results of November 1994 Aquifer Test near Castroville \\
\hline $\begin{array}{l}\text { Kenneth D. Schmidt and } \\
\text { Associates }\end{array}$ & July 1989 & $\begin{array}{l}\text { Results of Three-day Aquifer Test at Spreckels in } \\
\text { January } 1989\end{array}$ \\
\hline $\begin{array}{l}\text { Kenneth D. Schmidt and } \\
\text { Associates }\end{array}$ & July 1989 & $\begin{array}{l}\text { Results of Three-day Aquifer Test at Spreckels in } \\
\text { January } 1989\end{array}$ \\
\hline Leedshill-Herkenhoff, Inc. & 1984 & $\begin{array}{l}\text { Salinas Valley Seawater Intrusion Study Preliminary } \\
\text { Task Report } 1\end{array}$ \\
\hline Leedshill-Herkenhoff, Inc. & January 1985 & Salinas Valley Seawater Intrusion Study \\
\hline Luhdorff and Scalmanini & February 1986 & $\begin{array}{l}\text { State WRCB Groundwater "Hot Spots" Project Well } \\
\text { Testing and Site Characterization Salinas Area Final } \\
\text { Report }\end{array}$ \\
\hline Manning, J.C. & 1963 & $\begin{array}{l}\text { Resume of Ground Water Hydrology in Salinas Valley, } \\
\text { California (American Association of Petroleum } \\
\text { Geologists - Society of Economic Paleontologists and } \\
\text { Mineralogist Annual Spring Field Trip Guidebook: } \\
\text { Geology of the Salinas Valley and the San Andreas } \\
\text { Fault. }\end{array}$ \\
\hline $\begin{array}{l}\text { Monterey County Flood Control } \\
\text { and Water Conservation district }\end{array}$ & May 1960 & Salinas Valley Geologic Investigation \\
\hline $\begin{array}{l}\text { Monterey County Flood Control } \\
\text { and Water Conservation District }\end{array}$ & May 1968 & $\begin{array}{l}\text { Investigation of an East Side Canal Project Salinas } \\
\text { Valley }\end{array}$ \\
\hline
\end{tabular}


Kennedy/Jenks Consultants

\begin{tabular}{|c|c|c|}
\hline Author & Date & Title \\
\hline $\begin{array}{l}\text { Monterey County Water } \\
\text { Resources Agency }\end{array}$ & May 1993 & $\begin{array}{l}\text { Approval of Change Order to MSA with Staal, Gardner } \\
\text { \& Dunne }\end{array}$ \\
\hline $\begin{array}{l}\text { Monterey County Water } \\
\text { Resources Agency }\end{array}$ & January 1998 & $\begin{array}{l}\text { Compilation of Geologic Cross Sections of the Salinas } \\
\text { Valley }\end{array}$ \\
\hline $\begin{array}{l}\text { Monterey Peninsula Water } \\
\text { Management District }\end{array}$ & July 1997 & $\begin{array}{l}\text { Technical Memorandum 97-04 summary of } 1996 \\
\text { Seaside Basin Monitor Well Installations }\end{array}$ \\
\hline Pettit, Walt & September 1993 & $\begin{array}{l}\text { Letter to Rick Antle: Salinas Valley Groundwater Basin } \\
\text { Seawater Intrusion }\end{array}$ \\
\hline $\begin{array}{l}\text { Salinas Valley Groundwater Basin } \\
\text { Hydrology Conference }\end{array}$ & June 1995 & Hydrogeology and Water Supply of Salinas Valley \\
\hline $\begin{array}{l}\text { Salinas Valley Reclamation } \\
\text { Project Castroville Seawater } \\
\text { Intrusion Project }\end{array}$ & March 2001 & Seawater Intrusion Program \\
\hline Staal, Gardner \& Dunne, Inc. & July 1993 & $\begin{array}{l}\text { Hydrogeologic Study Salinas Valley Groundwater Basin } \\
\text { Seawater Intrusion Delineation/Monitoring Well } \\
\text { Construction Program }\end{array}$ \\
\hline Staal, Gardner \& Dunne, Inc. & 9 March 1993 & Proposal for Hydrogeologic Services \\
\hline Thorup, Richard R. & 20 April 1976 & $\begin{array}{l}\text { Report On Castroville Irrigation Project Deep Test Hole } \\
\text { And Freshwater Bearing Strata Below the } 400 \text { Foot } \\
\text { Aquifer, Salinas Valley, California }\end{array}$ \\
\hline Thorup, Richard R. & 20 March 1985 & $\begin{array}{l}\text { Summary Hydrogeological Report on the Relationship } \\
\text { of the } 4 \text { Recently Completed Water Wells On Fort Ord } \\
\text { Military Reservation to the Salinas Valley } 180 \text { and } \\
400 \text { Foot Aquifers }\end{array}$ \\
\hline Tinsley III, John & August 1975 & $\begin{array}{l}\text { Quaternary Geology of Northern Salinas Valley, } \\
\text { Monterey County, California Dissertation }\end{array}$ \\
\hline Todd, D.K. & September 1988 & $\begin{array}{l}\text { Initial Assessment of Seawater Intrusion by Well } \\
\text { Leakage into the } 400 \text {-foot Aquifer, Castroville Area }\end{array}$ \\
\hline Todd, D.K. & June 1989 & $\begin{array}{l}\text { Sources of Saline Intrusion in the } 400-\text { Foot Aquifer, } \\
\text { Castroville Area, California. }\end{array}$ \\
\hline U.S. Army Corps of Engineers & May 1979 & Salinas-Monterey Bay Area Urban Study Draft Annex F \\
\hline Yates, E.B. & 1988 & $\begin{array}{l}\text { Simulated Effects of Groundwater Management } \\
\text { Alternatives for the Salinas Valley, California (U.S. } \\
\text { Geological Survey Water-Resources Investigation } \\
\text { Report 87-4066) }\end{array}$ \\
\hline
\end{tabular}

